\title{
Lapurdum
}

Euskal ikerketen aldizkaria | Revue d'études basques |

Revista de estudios vascos | Basque studies review

$17 \mid 2013$

Numéro XVII

\section{Distopia eta paradisua Euskal Hirian : Bernardo Atxagaren Etiopia makrotestuaren irakurketa semiotikorako hausnarketa kritikoak}

\section{Maria Lourdes Otaegi Imaz}

\section{(2) OpenEdition}

\section{Édition électronique}

URL : https://journals.openedition.org/lapurdum/2425

DOI : 10.4000/lapurdum.2425

ISSN : 1965-0655

Éditeur

IKER

Édition imprimée

Date de publication : 1 octobre 2013

Pagination : 109-173

ISBN : 978-2-86781-409-9

ISSN : $1273-3830$

Référence électronique

Maria Lourdes Otaegi Imaz, «Distopia eta paradisua Euskal Hirian : Bernardo Atxagaren Etiopia makrotestuaren irakurketa semiotikorako hausnarketa kritikoak», Lapurdum [Linean], 17 | 2013, Sarean emana----an 15 novembre 2015, kontsultatu 23 juillet 2021. URL: http://journals.openedition.org/ lapurdum/2425 ; DOI: https://doi.org/10.4000/lapurdum.2425 


\title{
Distopia eta paradisua Euskal Hirian:
} Bernardo Atxagaren Etiopia makrotestuaren irakurketa semiotikorako hausnarketa kritikoak

\author{
Maria Lourdes OTAEGI IMAZ \\ Euskal Herriko Unibertsitatea UPV/EHU
}

\begin{abstract}
hi hintzena
bi arraia zaharren gurutzaketa

galdu da, galdu haiz

hautsi da ANPHORA

eta mila ispilutan multiplikatua

ez haiz azken irudi ezabatua baino

ilunaz zipriztinduz bekokia

eta hausterrez

laberintoaren harri txintxarretan

zauritzen hire oin birginak
\end{abstract}

\section{Abstract}

Artikulu honen xedea Bernardo Atxagaren Etiopia liburuan mamituriko ideia poetikoak berraztertzea da, abiapuntutzat hartuz haietan Paradisuaren desioak eta Distopiaren esperientziak egiten duten talka. Azkerketa burutzeko, kritika-ildo semiotikoa jarraituko da, eta Ikasketa Kulturalen laguntzaz, testuaren irakurketa berritua proposatu nahi da.

Horretarako, lehenik ildo pragmatikoa berrikusiko da, neobanguardiaren sustrai sozio-politikoak azaleratu eta, diktadurak idazleen literatura-poetiketan izandako eraginaren haritik, egilearen elkarrizketa eta hitzaldietan adieraziriko poetikaren zantzuetan ezarriko da fokua. Artikuluaren bigarren zatian, Etiopiaren irakurketa testualari eta transtestualari ekingo zaio; horretarako lehenik, enuntziazio lirikoan eginiko hautu esanguratsuak deskribatuko dira. Hirugarrenik, liburuak bere osotasunean duen makrotestu-izaera hartuko da kontuan testuaren irakurketa sinboliko eta interpetatiborantz egiteko, horretarako, egitura, paratestuak eta topografia esanguratsuei buruzko irakurketa burutuz. 


\section{1.- Sarrera metodologikoa}

Bernardo Atxagararen liburuetan, hastapenekoetatik azkenekoetara, gutxi edo asko, utopia bat gauzatzeko lehiatzen diren pertsonaiak topatzen ditu irakurleak. Bere idazlanetan, hala fikiziozkoetan eta poetikoetan, nola saioan, ildo tematikorik iraunkorrenetako bat da, agi denez. Topografia zehatzetan mamitzen diren "lekuak" bilakatzen dira utopia horiek eta, sarritan, haien aurkakoak dira bilakatzen, distopiak, alegia, infernu itogarriak. Idazle gisa utopia eta distopia horiez diharduenean, halere, munduaren izaerari buruzko hausnarketak egitea baino, haietan mamitzen diren gizakiaren barne munduak zaizkio interesatzen. Denok oroi ditzakegu horietako batzuk. Esate baterako, paradisuaren nostalgiak errotik kutsaturik bizi da Obabako Albania auzoko maistra gaztea, "Post tenebras spero lucem"en bere bakardadearen eta isolamenduaren sufrimendua gainditzeko iraganeko egunetara behin eta berriro itzultzen dena. Aldiz, itzulera ezinezko denean, paradisu berriak eraikitzeko ahaleginetan ikus ditzakegu pertsonaiak, Arkadia berriak sumatu nahian, Soinujolearen semea bezala, eta iraganeko paradisuaren galeraren melankoliaz. Esango litzateke kaosaren etorreraren aurretiko Eden hura galdu genuelako, "jatorrizko zauri hori" giza naturaren bihotzik antzinakoenean idatzirik dagoela iradokitzen digula egileak, eta hara itzultzeko saioa direla gure ahaleginik behinenak.

Pentsamendu-ildo utopiko berean kokatzen ahal dugu Atxagaren Euskal Hiriaren egitasmoa ${ }^{1}$, laurogehita hamarreko hamarkadan ezagutzera emandakoa eta Julio Medem-en Euskal pilota. Larrua harriaren kontra (2003) filmak nukleo argumental gisa harturikoa. Utopia berri baten proposamena iradoki zuen, bere ustez milurteko berriko euskal errealitate askotarikoari zegokion bizikidetza proposamen bat. Ez zen halere, utopia heroiko bat, horietatik nahikoa eta gehiegi izan omen direlako jadanik, "sino una utopía que tenga por objeto, por sueño, la mejor convivencia de todos cuantos vivimos aquí. Yo he llamado a esa utopía Euskal Hiria" 2

Zalantzarik ez da ordea, proposamen horrek oso zalantzan jartzen dituela haren poetikaren espiritu posmodernoaren aldeko iritziak, batez ere espiritu hori gizarte auziekiko indiferentzia edota axolagabezian ezaugarritzen dela diotenenak behintzat ${ }^{3}$.

1.- Ikus "Astoa eta Euskal hiria" dela eta egileak atxaga.org web orriaren blogean eskegitako artikulua. http:// www.atxaga.org/blog/17 [azken ikustaldia 2013-X-08]

2.- 2007ko Udako Ikastaroetan irakurri zuen "Otra mirada" izeneko hitzaldia, non, besteak beste, Hiriarekin izandako esperientzia pertsonalaz mintzatu zen. Han auzi linguistikoak eta klase auziek duten interakzioaz diharduen zorroztasun handiz: "Se dirá, con toda razón, que este clasismo, esta antipatía bastarda hacia lo vasco, no es visible en los jardines de la Corte ni en los pasillos de los edificios de gobierno, y que tampoco aparece en los programas de los partidos políticos estatalistas; que a ningún gobernante actual se le ha pasado por la cabeza prohibir la lengua vasca - por ejemplo en los epitafios de las tumbas, tal como ocurrió durante parte de la dictadura-; se dirá eso, repito, con toda razón. Porque es verdad. Pero es innegable que esa mirada negativa, esa antipatía, ese clasismo forma parte del conglomerado de ideas, creencias y sentimientos, de una parte de la sociedad; no del de todos los que votan a partidos estalistas, pero sí del de algunos, del de bastantes. Y no como un elemento más, sino de forma más radical; como el nutriente en la fruta". Ikus www. atxaga.org/testuak-textos/otra-mirada

3.- Ikus, besteak beste, Xabier Montoiaren Euskal hiria sutan (2006) ipuin bilduma.Liburua polemika mitatz haren lekuko da. 
Nolanahi ere den, utopiei buruzko hausnarketan emandako azken urratsean, hots, 2012ko Paradisua eta katuak izeneko poema-disko liburuan, utopiaren bilaketari amets modernoen aura ezagun hori dario, hots, etorkizunerako asmoetan, funtzionalitatea edo bitartekoen biabilitateaz harantzago, nor markatu baten subjektibitatea aitortzen da muinmuinean. Espiritu kosmopolita eta indiferenteaz guztiz aurkakoa den "euskal" hiriaz ari da mintzatzen. Atxagaren idazlanez ere, Paradisuaren edota Utopiaren gaiaren errekurrentzia honen harira, gogora ekar genezake Jorge Luis Borges idazle argentinarraren esana, alegia, idazleak, zenbait argumentu errekurrentek xaxaturik idazten duela denbora epe luzeetan zehar, "soy decididamente monótono" ondorioztatuz ${ }^{4}$. Baina, ez da halakorik, jakina, ez Borges ez Atxaga ez baitira aspergarri gertatzen gai berari modu batera eta bestera eragin arren. Atxagaren kasuan, gainera, jadanik gaiaren inguruko hausnarketak egin duen ibilbide luzean zehar bilakera baten lekuko bihurtu gara. Azken ekarpenak asteasuarrak "La utopía" [Utopiari buruz] izeneko hitzaldian ${ }^{5}$ burutu zuen hausnarketa dugu, utopien gaiak egilearengan hartzen duen zabaltasunaren lekuko gisa.

Hasieratik hasi behar da ordea, eta gaurkotik iraganeko poemetara joz, 1978an bere ibilibide literario arrakastatsuari hasiera eman zion Etiopia liburu hartan ere, izenburura ekarri zuen egileak pentsamendu ildo hori izendatzen duen hitza bera: Utopia. Halabaina, modu paradoxikoan egiten zuen aipua, zere, Desparadisua zen poetak mintzagai zuena, bai Ziutateaz (1976) eta bai Etiopia (1978) bezalako lanetan. Amesgaiztoetako Ziutate distopiko batean jausi denak edota Paradisutik egotzia izan den Etiopiako errebeldeak aurkitzen duen basamortu mitikoa eta amets gaiztoa ditu mintzagai.

Etiopia izenburuaren eta Utopia hitzen arteko ageriko homonimiagatik, interpretazio ildo ezaguna izan da euskal kritikarentzat poetak liburu horretan desiratuaz guztiz bestelako errealitatearekin, desparaiso mitikoarekin egiten duela topo. Horregatik, berria ez izan arren, emankor deritozogu gaur ere distopia/utopia ardatzari eusteari Ziutateaz (1976) eta Etiopia (1978) idazlanetan islatutako unibertso poetikoez mintzatzerakoan, gaur egungo bere poetikaren gai ardatzetako bat izaten jarraitzen baitu topos literario aberats horrek. 1976 eta 1978ko lehen narrazio eta poema liburuetatik azken honetarainoko hausnarketa-haria izateaz gain, bere eleberri nagusi biren ardatzean ere hor dirau utopiari buruzko pentsamenduak. Horra, batetik, Gizona bere bakardadean (1993) eleberrian ikus daitekeenez, utopia komunistaren frakasoaren zioak, pertsonaia "kontzientziatu" baten traizioan gauzatuak ${ }^{6}$. Gisa berean ezin ahantzi Soinujolearen semea (2003) eleberrian ere sakoneko gaietako bat da dela paradisuaren ideia, Iruaingo Arkadia galdutik Ameriketako Eden berrira eginiko ibilbidearen trantsitoa baitu liburuko mintzagai nagusi ${ }^{7}$. Hona, Dominique Aussenac kazetari frantsesari egileak argiturikoa, itzulpenaren frantsesezko argitalpena zela eta:

4.- "El informe Brodie"ren hitzaurrean (Obras completas, 1970, II tomo, pp 400)

5.- Hitzaldia Foro Claudio Rodriguez-en irakurri zuen, Zamoran, 2012 an. Egilearen baimenaz jasoko dira artikuluan zehar hitzaldi hartako zenbait atal (2011ko urriaren 4ko bertsioa). Geroztik, El paraíso y los gatos (Pamiela, 2013) liburaren eranskin gisa argitaratu da

6.- Bai eleberrian eta bai 2012ko "Sobre la utopia" hitzaldian aipatzen du Atxagak historiaurreko gizakiek ere bazituztela koketeriak: duela 40.000 urteko arbaso europarrek, Nassa Reticulata izeneko moluskoa biltzeagatik, apaintzeko soilik balio zien oskolarengatik, ibilbide izugarri luzeak egiten baitzituzten.

7.- Le main du signe, 2007ko apirilean). Ikus www.atxaga. org esteka (2013-04-15ean irakurria). 
"El tema de fondo es el paraíso. Mientras escribía la novela escribí varios poemas con ese tema. Uno de ellos se titula «La vida según Adán», y trata de saber lo que le ocurrió a Adán la primera vez que enfermó después de salir del paraíso. ()Estados Unidos tiene, efectivamente, una dimensión simbólica, la que tuvo un día para los pioneros, o incluso para los que huyeron de Europa a causa de la pobreza o a causa de la persecución política de que eran objeto. Es decir, que no se trata del país real que ahora se cita en los periódicos con motivo de la guerra de Irak o los protocolos de Kyoto, sino el país que estuvo en la mente de aquellos que, al llegar allí de Europa, creyeron estar cerca del paraíso. Es una de las cosas que más me impresionó cuando anduve por Estados Unidos: la cantidad de topónimos que allí hacen referencia al paraíso. Cuántos lugares se llaman por ejemplo «edén»".

Dakigunez, utopia batean biltzen dira zoriontasun bilaketaren dimentsio pertsonalak, erlijiosoak, sozialak eta politikoak ${ }^{8}$, izan ere, paradisuaren desioa gizakiaren baitan sakon errotuta dagoen guraria da, infernu hurbilari aurka egiteko, besterik ez bada ere sarritan. Bere baitan errotzen du inbertsio amets bat da, errealitatearen klabe jakin batzuetan oinarritua eta giza multzoen premien sinplifikazio erradikalegiak eginez. Hortik omen letorke haien frakasua, egilearen iritziz. ${ }^{9}$

Paradisuko edo Utopiako gai honen ildo interpretatibo emankorra gure artikuluaren aztergai gisa ${ }^{10}$ aurkeztu eta probatu ondoren, aztergai gisa hautatu dugun esparrura hurbilduko gara hurrengo lerroetan, Etiopiako poemetan egileak islatu zuen desparadisuaren zutabeak aztertzeko helburuz eta Ziutatea beste begirada batez geureganatzeko asmoz.

Horretarako, metodologia semiotikoak iradokitako urratsak jarraituko dira azterlan honetan, literatura den komunikazio sozialaren berri emateko azterbiderik egokiena delakoan. Semiotika literarioaren postulatuei jarraiki, literatur obra komunikazioa helburu duen zeinu sistematza da; hain zuzen ere, faktore hori baita Semiotikak literatur kritikaren esparrura ekarri duen berrikuntza nagusia, testuaren eta testuinguru pragmatikoaren arteko interakzioa.. Iuri Lotman-ek Estructura del texto artístico lanean baieztatzen zuen gisan, "el arte es uno de los medios de comunicación"11 eta, hain juxtu, ikuspegi hori da Estrukturalismoaren ondoren Semiotikak testu literarioaren ikerketarako ekarritako berrikuntza nagusietakoa. Literaturalana egitura gisa sumatzea oinarrizko printzipioa zen Formalismoarentzat (azken etapan) eta

8.-2011ko Donostiako Miramar Jauregiko Euskal Herriko Unibiertsitatearen Udako Ikastaroetan "Utopias y otros sueños" izenburudun topaketak zuzendu zituen, hiru alor bereiziz, utopia urbanoak, utopia erlijiosoak eta utopia politikoak.

9.-Elegí esta dimensión utópica porque, como he dicho antes, me interesa el interior de las personas. En ese interior, siempre hay un anhelo de utopía, de paraíso. Un anhelo que, naturalmente, es el reverso de su vida real, llena de sufrimiento o de mediocridad." (Aussenac, La main du signe).

10.-Bistakoa denez, Paradisua, Eden, Arkadia sinonimo literariotzat hartzen dira hemen, hots, erlijioek fededun zintzoentzat destinatua den Zerua, kristau fedean, jatorrizko bekatuaren aitzinetik gizakien bizileku zoriontsua zena. Utopia aldiz, gizarte eredu perfektuaren proiekzio literario eta filosofikoa da, Thomas Mororen liburuaren izenburutik ateratako izendapenaz bataiatua eta geroztik beste hainabt formulazio ezagutu dituen. Lan honetan zehar ordea, aipatu diren termino horiek guztiek esanahi berdin berdina izango dute, Atxagaren testuetan sinonimotzat hartzen direnez, nahiz eta, horien erabilera ez den guztiz arbitrarioa, eta azken terminoa, utopia erabiltzen duen bere esanahi zehatzean.

11.-Op. Cit., 17. 
Estrukturalismoarentzat, baina zeinuari komunikazio-alderdia eranstea falta zen, eta horixe egin zuen Semiotikak. Horregatik, ikerketa semiotikoak ikuspegi zabal batetik hurbiltzen da literatur obrara. ${ }^{12}$

Semiotikaren planteamendu orokor honetatik abiatzen gara, beraz, gure ikerketan. Testu artistikoaren zeinuak, hizkuntza poetikoak, hizkuntza naturaletik bereizten duen berezitasun batzuk ditu; halaber, arte gisa komunikazioa du helburu eta komunikazio horretan faktore desberdinek hartzen dute parte. Faktore horiek hiru dira nagusiki, zeinuak berak, subjektuak eta testuingurua; eta komunikazioan parte hartzen duten hiru elementuon arteko erlazioak aztertzea da semiotikaren helburu oinarrizkoa. Hortaz, gure ikerketak bi hurbilpen nagusi burutuko ditu. Batetik, obrarako hurbilpen pragmatikoa gauzatuko dugu, zeinetan obrak zeinu sistema ireki gisa bere testuinguruarekin dituen erlazio anitzak aztertuko dugun, baina biografikoan, kulturalean eta sozio-opolitikoan, baina literarioan luzatuko gara bereziki, horrek obraren irakurketari ekarpen esanguratsua egin liezaiokeela baiteriotzogu.

Agerikoa da literatur obraren testuinguruaren konplexutasuna: beronen eta obraren arteko erlazioak bilatu eta aztertzea da pragmatikaren helburua. Baina hurbilpen pragmatikoa ikerketa semiotikoaren osagai funtsezkoa da. Ondotik datoz, maila sintaktikoaren eta semantikoari dagozkion azterketak, izan ere testuaren interpretazioa faktore intratestual eta estratestualek baldintzatua dago eta, beraz, literaturaren ikerketa oso batek obraren balio intratestualak ere hartu behar baititu. Semiotika literarioaren iritziz, literariotasuna garai eta kulturen araberako izateak ez du esan nahi ez dagoenik objektiboki hitz egiterik poesiaegiturez, hots, bere egitura-eraketa duen eta irakurleagan efektu jakin batzuk eragiten dituen diskurtso mota berezi batez.

Literatura-testu baten interpretazio-aniztasuna arteari berari datxezkion kausei zor zaie, arteak kodetze ezin konplexuagoa duelako; ez zaie zor irakurlearen apetari edo harrerabaldintzei, soilik. Izan ere, Lotman-edioen moduan, "literariotasuna" balio aldakorra da gizarteari eta kulturari loturik egon arren, hizkuntza poetikoa "bigarren mailako komunikazio lenguaia modelizatzailea" da, eta arteari berari dagokio, eta horregatik esan daiteke testuak baduela oinarrizko edo funtsezko egitura bat. Ildo teoriko honi jarraiki, beraz, gure ikerketan testuaren azterketa pragmatikoaz gain, hau da testuaren esanahia baldintzatzen duten alderdi soziokulturalez gain, maila testualean gauzatzen den ikerketa burutuko da zeinuek elkarrekin eihotzen duten egitura aztertuz, maila sinbolikoaren azterketa eta interpretazio saio bat burutzeko. Maila ezberdikeko azterketen kohesio horretatik sor baitaiteke obraren balio intratestualak eta estratestualak argitzeko bidea. Azken batean, ikerbide honek aukera ematen digu, batetik, obraren azterketa testuala gauzatzeko, zeinuaren formak bere erreferentearekin ezartzen dituen erlazio anitzak deskribatu eta interpretatzeko ahalegina egiteko helburuz.

12.- Karlos Otegi Karlos Otegik berak Lectura semiótica lanaren sarreran zioen moduan: "Entendemos la semiótica no en un sentido limitado, como un sistema de signos enteramente autosuficiente en sí mismo, sino en un sentido amplio, como sistema abierto de códigos de signos considerados en sus dimensiones intratextuales y extratextuales: una teoría semiótica completa. Incluye una sintaxis o relación y combinación de los signos entre ellos; una pragmática, es decir, las relaciones de los signos con sus usos, sus efectos y con los sujetos que los utilizan, y la actualización de la lengua en un discurso por una enunciación realizada en situaciones contextuales concretas; y una semántica o relación de los signos con su significación, con los objetos de la realidad." 


\section{ATALA: AZTERKETAREN MAILA PRAGMATIKOA}

\section{1. Sarrera}

Bernardo Atxagaren obra poetikoa, Etiopia, 1978an Bilbon argitaratua, garai hartan euskarazko liburuen edizioa inguratzen zuen isiltasun hesiaren erakusgarri garbia da eta baita, aldi berean, Euskal Herriko kultur giroetan eragin handia zuen atxikimendu ideologiko militantearen araua gainditzeko ahaleginaren lekuko bizia. Horregatik, maila testualean abangoardiazko lanen parametro estetikoen arabera deskribatu aitzinetik, egoki da idazlan haren formulazioa inguratzen zuen kontestu pragmatikoari ongi erreparatzea, testua markatu zuelako lorratzak ugariak baitira.

Demokraziaren etorrerako trantsizioaren urteetan (1975-1985) euskal literatur sistema doi hasia zen bere produkzio bideak sendotu eta indartzen; argitaletxeak eta banaketa-enpresak sortu ziren, eta, denbora berean literatura horren hartzaile kopuruak ere handitu egin ziren eskolatze elebidunaren eta helduen alfabetatzearen bidez. Ondorioak euskal liburugintzaren esparruan zehaztera joz gero, ikus liteke literatura-liburuen garapenaren kopuruek eginiko ibilbidea guztiz adierazgarria izan zela. (Torrealdai, 1997, 193).

Halabaina, euskal literaturaren garapena demokraziarekin batera heldutako hizkuntza plangintzaren eraginak fagoratzen hasia bazen ere, oroitu behar da testuinguru globalean, espektakuluaren gizartea nagusitzen hasi zela eta kultura libreskoak lehiakide gogorrak zituela jadanik. Guy Debordek ${ }^{13}$ iragarritako komunikabideen lehen mailako protagonismoaren aroa heltzen ari zen eta literaturaren erreferentziazko baloreak irudiaren kulturara aldatzen hasiak ziren abiada handiz. Horregatik, kultur sorkarien azokan eragin handieneko hedabide ahaltsuek erronka egiten zieten haien babesik gabeko idazleei, bereziki euskaraz idazten zuten sortzaileei, urteetako zailtasunen osteko aro itxaropentsua iristearekin batean. Maria Jose Olaziregik "Luces y sombras de la crítica vasca"14 artikuluan dioenez, gero eta sortzaile eta irakurle trebatu gehiago izan arren, euskal literaturak bere produkzioa ezagutzera emateko bitartekotzako espazio birtualean izan ditu betidanik hutsune larrienak. Bernardo Atxagak euskal literaturak "erresonantzia-kaxa" motela duela deitoratuz deskribatu izan du egoera hor eta irakurlearenganako zubia eraikitzen duten osagaiak falta zituela gehienik, hots, literatur agenteak, sari errespetatuak, idatzizko eta ikus-entzunezko komunikabideetako sustapena, prentsa adituko elkarrizketak, erreseinak, iruzkin-kritikak, liburudendetako erakusleihoetako promozioak, itzulpenak, etab. ${ }^{15}$

Jakina denez, Etiopia liburuak bi argitaraldi ia berdinak izan zituen urte gutxiren buruan, lehena 1978an eta bigarrena 1983an. Geroztik, gaztelaniara itzulia izan da zatiz Poemas E Híbridos (Visor, 1990) izenburuarekin, eta Nueva Etiopian (El europeo, 1996). Azkenik, poemetako batzuen bertsio kantatuak biltzen dituen CDarekin batera eman dira argitara

13.- La Société du spectacle (Buchet-Chastel, 1967 ; Champ libre, 1971 ; Gallimard, 1992).

14.- (Oihenart, 19 zb., 2002, 123-144)

15.- Egoera oso ahulean zegoen trantsizioaren urteetan, eta neurri batean hortxe dirau gure sistemaren ahuldadeak, horretara bideraturiko bitartekoak erruz ugaritu diren arren. Euskal industria kulturalaren gabeziak salatzen ditu gaur egun ere Bernardo Atxagak (Ikus Elkar adizkariari emaniko elkarrizketa, 2009, 15 zb., 4-5) 
hango zenbait testu. Antologia eta selekzio ugari dira lehen ale hartatik hartutako poemak jasotzen dituztenak, eta ez dira gutxitan berrargitaratu hango zenbait testu, beste berriago batzuekin batera, euskaraz nahiz gaztelaniaz, frantsesez, ingelesez, alemanez, finladieraz edo italieraz. Edizio itzuli horietako bat soilik aipatzearren, gogora bedi Poemas \& Híbridos obraren italierazko itzulpenak egin zuela, hain zuzen, Cesare Pavese sariaren irabazle 2003an ${ }^{16}$. Egileari buruzko bibliografia zabalak ezagutzera emandako zerrenda gehiago ez luzatzeko, ondoriozta dezagun nazioartean bateko eta besteko itzulpen partzialek eta selekzioek bermatzen dutela sendoki haren produkzio lirikoaren kalitatea eta garrantzia ${ }^{17}$.

Euskal poesiaren testuinguruan Etiopiari seinalatzen zaion tokiaz hitzeginez, gogora dezagun XX. mendeko olerkigintzan aro berri baten, neoabangoardiaren hastapeneko obra izatea aitortzen zaiola aho batez ${ }^{18}$, laurogeietan fruitu aipagarriak ekarriko dituen neobanguardismoa eta esperimentalismoaren lehengo formulazio zabal eta aho batez aitortua; halere, euskal sistemari dagokionez, aipa dezagun, bukatzeko, olerkigintza genero hegemonikoa izateari uzten ari zen une-uneko obra dela; izan ere, J. M. Torrealdarien datuen arabera, 1985etik hona beherakako datu nabarmenak besterik ez baititu eskuratu olerkigintzak, narratibaren nagusitasunaren mesedetan (1997:323).

Literatur obra bat aurkezten hastean, ohikoa izaten da garaiko korronte edo "eskolaren" batekin erlazionatzea, honela, irakurleek proposatzen zaien obran topa dezaketen literatur diskurtso moduari buruzko erreferentzia lasterra izango baitute. Bereziki da gomendatzekoa, gainera, erreferentzia hori eskaintzea liburu honen kasuan liburuaren itzulpen osoa egiteke egonik eta euskal edizioak ere agortuak egonik aspaldidanik. Atxagaren poesiaren kasuan, euskal poesiaren kritiko eta historialariek neobanguardiaren erreferentziari heldu izan diogu, eta, neobanguardiari atxikitze hori hain da onartua autoreari buruzko lan kritikoetan, non artikulu honetan bereziki europar neobanguardiaren barruan sartzen diren sorkuntzaildoetako batekin lotzen duten zehaztapen batzuk egitea soilik hartuko den helburutzat.

Asmo horri heldu aitzin, ordea, pragmatika mailan testuinguruari eta mugimendu literarioei ezinbestez erreferentzia eginez, ezinezko zaio kritikariari poesiak, ia esateko, ezinbestean, aztergai duen autorearen eta haren bizi esperientziaren aztarna, poeman agertzen

16.- Ikus Olaziregi, M.J. Six Basque Poets, Ar Publications, Yokshire (U.K.), 2000, pág. 31.

17.- Hona hemen horietako zenbait: Vuelta (México), Jabbuch del Lyrik (Alemania), Die horen (Alemania), Lichtungen (Austria), Lyrikklubbs Bibliotek (Suecia), Tabacaria (Portugal), Modern Poetry in translation (Reino Unido), Poetry London (Reino Unido), Labyrint (Republica checa), Guggenheim Magazine (USA), Metamorphosis (USA), The Threepenny Review (USA), Fence Magazine (USA), Hayden's Ferry Review (USA). Internet (Other Voices, Transcript. Hainbat poesia katalogotan argitaratu dute: Poetry on the road (Amenaza, 2002), Cuir Annual (Irlanda, 2003), Frontera Permeable. Atxaga por Landa (Euskadi, 2203), Festival de Poesía Cidade de Betanzos (Galicia, 2006). Poesia antologietan jaso dituzte haren testuak, hala nola, Javier Gomez-Montero, Territorien der Lyric in Spanien (Edition Tranvía, Verlar Walter Frey, Berlin, Alemania, 2001); Kevin Prufer eta Wayne Miller-ek New European Poets (Graywolf, USA, 2008); Tom Lombardo, The poetry of Recovery. After shocks (Santa Lucia Books, Atlanta, USA, 2008) eta Rosso Primo (Mavida, Italia, 2008).

18.- Ikus bibliografian adostasun horren lekukotza honako liburuetan: Jon Kortazar, Literatura vasca. Siglo XX (Prames, Zaragoza, 2000), Luma eta lurra (Labayru, Bilbao, 1997); Iñaki Aldekoa, Euskal literaturaren historia, (Erein, Donostia, 2008) edota Lourdes Otaegi, XX. mendeko euskal poesia (www.basqueliterature. com, 2011) eta Mari Jose Olaziregi (zuz) Basque Literature, University of Reno,Nevada, USA, 2013. 
den mundu pertsonal eta kolektiboaren isla gisa ez hartzea. Izan ere, Serge Doubrovsky, genero autobiografikoen teorizatzaile handiak esan bezala, asmo interpretatzailea buruan harturik hurbiltzen garenean, idazlan guztien aztertzaileok obraren kritikarik onena egin nahi izaten baitugu, eta kritika hori ez dugu lortzen xehetasunik txikieneraino iristean, klabe nagusiak zein diren esaten asmatze dugunean baizik.

Horretara, beraz, eta gogoan harturik zer une historikotan duen sorrera aztergai dugun obrak, apika ez da soberan izango gogora ekartzea zer-nolako egoeran idatzi zen. Esan gabe doa, frankismoaren amaierako testuinguruaz ari garela eta gerora trantsizioa deitu zaion garaiko lehen urteez, bai eta Euskal Herriak zituen ezaugarri bereziez ere, alegia, hizkuntz arazoak, gizarte, kultura eta politika arazoak biziagotu zituen testuinguru gatazkatsuaz.

Etiopia, 1978an argitaratu zen Atxagaren obra poetikoa, Pott argitaletxeak argitaratutako obra bakarra izan zen. Argitaletxea ezaguna zen izen berarekin 1977az geroztiz zabaltzen eta banatzen zen aldizkariagatik. Joera banguardistako euskarazko beste literatur aldizkari batzuk ere sortuak ziren aitzinetik, eta bereziki dira aipatzekoak Donostian 1975 eta 1976a bitartean argitaratu zen oso iraupen laburreko Ustela aldizkariaren hiru aleak. Aldizkari horretan, antzerki abanguardistako pieza laburrak argitaratu zituen Atxagak, eta bere lehen testu poetikoak ere bai ${ }^{19}$. Bai Ustelak bai Pottek bazuten biek elementu bat irakurle gazte eta unibertsitarioen belaunaldiari oso erakargarri gertatu zitzaiona: undergrounda zen, nazioarteko fenomeno kulturalaren oihartzuna zekarkioten. Ziur naiz izango dela beste hitzik ere, baina ez dut oraingoz zorioneko underground kalifikatiboa baino hoberik topatzen modu egungoagoan definitzeko. Underground "anti-sistema" edo kultura ofizialaren aurkakoaren zentzuan zihoan mugimendua zen.

Baina zein kultura ofiziala? Benetako kultura ofizialaren, hots, frankismoaren aurka edota euskal kultur munduaren kasuan, lehenengo hauteskundeen bidez erakundeetara iristear zen nazionalismoa demokratiko "ofizialaren" kultura? Bien aurka, jakina ${ }^{20}$.

Joseba Sarrionaindiak Bost idazle liburuan aipatu zituen kontrakulturarekin bat egiten zutela Pott-en, kultura ofizialaren eta esparru politiko eta sozialean nagusi ziren joeren kontrako posizionamendua hartzen zutela, kontsigna ideologikoetatik urrun eta literatur arloaren autonomia erreibindikatuz:

"Bestalde, sasoi hartan liburu gehienak debekuaren mugan zeuden oraindik.

19.- Ordurako argitaratuak zituen Puntua eta borobila (1972)nahi Ziutateaz eleberria (1976). Etiopia ulertzeko balio handikoa da Ziutateaz eleberria, bi urte aintzinagotik idatza denez, bien arteko loturak ugariak baitira. Bietan suma daiteke literatura fantastikoaren zaletasuna, bereziki Marcel Schwob eta Jorge Luis Borgesen ildokoa. Bestalde, generoen hibridaziorako joera suma genezake bietan. Azkenik, Ziutateaz eleberrian dauden testu poetikoek enuntziazio lirikoari dagokionez, Etiopiako monologo dramatikoarekin harreman hestuan ikus dezakegu. Ez da ustegabea Koldo Izagirrek, Ustela aldizkari literarioan partaide izan zenak, Ziutateaz-eko lau poema hautatu izana Bernardo Atxagaren poemen antologia egitean (XX. Mendeko poesia kaierak. Bernardo Atxaga, Susa, Zarautz, 2000).

20.- Hona zenbait datu testuinguru sozio-politikoari buruz: 1977-79 urteetan Euskal Kontseilua, Ramón Rubial sozialista lehendakari izandako erakunde preautonomikoa eratu zen. 1979ko hauteskundeetan irabazi zituzten hauteskundeak indar abertzaleek. Autonomia Estatutua 1979ko urriaren 25ean onartu zen. Krisi ekonomiko eta sozial latzak tentsio handia erantsi zion giro gatazkatsuan ETAren aktibitate armatuaren aldirik gogorrenatzat aipatzen da. 
Folklorea ez zitzaidan gustatzen, baina liburuen giroko euskal kulturak beste xarma bat zuen, klandestinitate eta modernitate aire bat, mundu ezkutu bat zegoen hor. Lur editorialeko liburuak gustatzen zitzaizkidan gehien. Euskal literatura 72 gogoratzen dut, "Malgizonen abenturismoa", "Borobila eta puntua" eta abar. Kontrakultura harekin identifikatu nintzen" (280-281)

Jose Mari Lasagabasterrek "underground literario" gisa deskribatu zuen hura (1984) Pott aldizkari prekarioaren bidez eman zen ezagutzera, oso era artisauan egiten zen guztia. Trantsizioko urte haiek irakite ideologikoz gainezka bizi izan ziren eta "ezinbesteko" formula salbatzaileak balira bezala elkarri inposatzen ziren proiektu politiko-kulturalez. Horregatik, bada, Atxagak parte hartu zuen bi aldizkari horiek, Ustela nahiz Pottek, ezagurrietako bat zuten jasotako ideien aurreko jarrera kritikoa, garai hartan kartsuki aldarrikatzen ziren egia absolutuen ezespen argi eta zuhurra, baina bazuten, halaber, jarrera ludiko eta ironikoa ere errealitate sozio-kulturalari bere aspektu asko eta askotan aurre egiteko bide dadaista hautatu $z^{2} e^{21}$. Sintesi moduan esan genezake, bi literatur aldizkari horien bidez iristen zela gugana literatur neobanguardia.

Ezin da doktrina estetiko guztiz koherenterik aurkitu Ustelaren (1974-75) edo Potten (1978-79) postulatuen inguruan biltzen zen taldearentzat, baina, argitasun apur bat emate aldera, har ditzakegu erreferentziatzat bi aldizkarie ere beren lehen aleetako orrietan argitaratu zituzten tankera neobanguardistako "manifestuak". Panpina ustelakoa proiektuari bere hastapenetan eutsi zioten bi idazleen, Bernardo Atxaga eta Koldo Izagirrerek izenpetu zuten manifestu bat, "Ez dezagula konposturarik gal, halare" izenburukoa. Han aldarrikatzen zuten "literatura herriaren ahotsa" dela, eta "gizartearen eraldaketaren eragilea dela", alabaina, helburua iristeko, literaturak plazara irten behar duela, bihotz eta hats berritu behar duela, hala ez bada, poesia panpina ustel bihurtzen dela"22. Literaturaren funtzio soziala aldarrikatzen zuten, noski, eta horregatik zuten helburutzat "euskal literaturaren urak indarrez harrotzea". Espiritu hori bera gorde du bere baitan Etiopiako testuak ere, Bertolt Brecht-en poesiaren oihartzunaren durundia. Ezin utzi bada azpimarratu gabe Euskal Herrian 1070ko hamarkadan poeta alemaniarren mezuaren oihartzun handia Atxagaz gain, Koldo Izagirre edo Joxe Austin Arrieta bezalako idazleetan. Poetika brechtianoaren eraginez, gurean artea historia eta gizartearen ulertzeko modu erabateko eta ekintzailea sustraitu zuen, hautu humanitario eta moralen lehentasunari atxikitako jarduera ezarri zuen, eta horrekin batera, lirika sentimentalistaren arbuioa, subjektibitate mengelaren hastioa.

\subsection{Pott, beat eta kontrakultura}

Pott aldizkaria Etiopia liburuaren eta Atxagaren ahots poetikoaren sorreraren testuinguru hurbila da, poemarioaren iturburuan dauden supuestu humano, sozial eta estetikoetako batzuk zehazten dituen paperezko mundua. Lehenik beharrezko zaigu geure

21.- Hizpide dudan garaiaren erakusgarri modura, ekar dezagun gogora Ustela aldizkariaren lehen alea Pampiña Ustela (1975), agintariek bahitu zutela "Elizaren eta Estatuaren kontrako irainak" zekarkiela-etalkus Ustela eta Pott aldizkarien bertsio digitalak: http://andima.armiarma.com/stel/info.htm

22.- Panpiña Ustela, 1975. Puede consultarse en Internet: http://andima.armiarma.com/stel/stelolinf.htm). 
buruari galdetzea nola interpretatu behar den Pott hitz onomatopeikoa. Badakigu bi adierazi badituela: alde batetik, akidura, neke ezin handiagoa, lehen egitea eta etsipena esan nahi duela, eta, bigarren adieran, porrot egitea, huts egitea. Hainbat testutan ikusi izan dut bigarren adiera hau besterik ez dela jasotzen aldizkariaren izenaren itzulpen gisa, baina, beharbada, egokiago litzateke, eta, adierazgarriagoa ere bai, lehen adierari atxikitzea, jarraian azalduko diren arrazoiengatik.

Jo dezagun lehenik Potten lehen alearen azal-orriaren paratestuak aztertzera: J. M. Susperregiren argazki batek lehen orrialde oso hartzen zuen: lau hipopotamo eguzkitan etzanda. Ez dirudi irudiak "porrota" irudikatzen duenik, bai, ordea, nekearen ideia, eskuarki esan ohi denez "leher eginda" erortzea zerraldo ${ }^{23}$. Ez du batere dramatismorik sortzen; aitzitik, komikoa ere gertatzen da. Irudia, gainera, koherentea da lehen ale horretan inprimatu zen manifestu mamitsuarekin, Ustelaren lehen aleak zekarrenak bezala ${ }^{24}$, jarrera jolasti, argitasunez beterikoa erakusten zuela: gogo artegatsu, bizi eta ekilearen lekuko. Beraz, baliteke taldearen izenak porrotik ez iradokitzea, are gutxiago europar poeta modernoek erakutsi zuten automarginaziorik edo malditismorik. Beharbada, Pottekoak ez ziren halako oihartzunaren bila ibili, eta bai, aitzitik, beren diskurtsoan helarazten zituzten ahalegin handiaren ondoriozko etsimendua eta desengainua.

Bestalde, berriz, gogora behar da lehen ale hark artikulu bat zekarrela "Poema liburu batetarako hitzaurregai bat", "taldeko apatridak" sinatua, betsela esanda, Atxagak berak izenpetua ${ }^{25}$. Berriro adierazi zuen idazleak literatura engaiatuaren ideia sartrearra bazter uzten zuela, eta bergisan aldarrikatu zuen ez zuela nazionalismo kulturalarekin bat egingo, bortizki defendatzen zuelarik euskal literatura kausa sozio-politikoaren zerbitzuko tresna bezala baliatzetik aldendu beharra ${ }^{26}$. Horren ordez, euskal literatura mundu zabaleko literaturarekin kontaktuan jartzea zuen helburu, inguru kreatibo berri batean txertatzea, guztia kutsatuko zuela zirudien halako "paranoia erreboluzionario"27 moduko bat sortzen zuten literaturaz ateko gatazka zalapartatsuen eraginetik libre ${ }^{28}$.

Bestalde, Pott hitzak, nekatu edo frustratu lehen adiera horretan, beat ingeles hitzaren esanahiarekin bat egiten du eta izenaren bidez Estatu Batuetatik hasi eta mundu osoan hedatu zen korronte kontrakulturalarekin: "beat generation"29. Hertsiki esateko, "beat" izendapena

23.- Ikus http://andima.armiarma.com/pott/aurki.htm

24.- Ikus http://andima.armiarma.com/stel/stel0linf.htm

25.- Aski da ikustea Etiopiako lehen testua Kain, lehen apatridari eskainia dela oroituz gero.

26.- Ikus Ur Apalategi (1999) "Un aspect de l'oeuvre de Bernardo Atxaga: la verité sort de la bouche des enfants", Atxaga Baionan, Hiria-Egan, p. 76).

27.- Ramon Saizarbitoria, Ene Jesus: Ez dira hauek literaturaz pentsatzen ibiltzeko denborak, entzuten da bazterretan." (Kriselu, Donostia, 1976) pp.129-130.

28.- Ildo berean mintzatu zen hainbat urte beranduako Joseba Sarrionandia, Bost idazle, Hasier Etxeberriarekin egin elkarrizketan Ikus Hasier Etxeberria (2002), Bost idazle. Alberdania, p. 132.

29.- Jakina denez, beat generation deitura Jack Kerouac eta John Clellon Holmes-en eskutik sortu zen 1948an. Jack Kerouac-ek erabili zuen New Yorkeko talde naten deitura orokortuz Ikus Go eleberriaren hitzaurrea (1952) (bigarren argitalpena Thunder Mouth, New York, 1997). Hona hemen bere hitzak: "Now I want to write to you about The Beat generation or simply the Beat ones - your book. You did the honest thing, the big thing, the good thing". 1952ko New York Times Magazine aldizkarian John Clellon Holmes berak argitaratu zuen "This is the Beat Generation" artikulua. 
poeta eta intelektuak inkonformistak batzuez aritzean erabiltzen zen 1950etan, hala nola, Jack Kerouac, Allan Ginsberg-en diskurtsoan. Herbert Hunckeren mintzaiera moduan izan omen zuen sorburu beat hitzak, "egurtu, frustratu" adiera literala hartzen omen zuen, eta hala dago jasota hirurogeietan argitaratu zen haren egunkari pertsonalean ${ }^{30}$. Ginsberg-ek eta Kerouac-ek belaunaldi oso baten ezaugarri komun bihurtu zuten kontzeptuaren sortzaile errekonozitu zuten Huncke; alabaina, beraiek izan ziren hurrengo hamarkadetan mugimendu kontrakultural amerikarraren aintzindariak.

Zerikusi handia izan zuen horretan Allen Ginsbergen jeinu-sormenak. "The howl" [Oihua] (San Frantzisko, 1956), poema idatzi zuen, belaunaldi harentzat guztiarentzat aski ezaguna den mugimenduaren hastapeneko testua edo manifestua. "The howl" poemaz ari garelarik, esanguratsu da. New Yorken poemaren lehen argitalpenaren berrogeita hamar hurrenaren karietara antolatutako oroitzapen ekitaldietan Atxagak emandako hitzaldiak Homage to Allen Ginsberg (2006) du izenburua ${ }^{31}$, eta Brick kanadiar literatur aldizkarian argitaratua da. Hitzaldi horretan, besteak beste, gogora dakar Atxagak "Howl" poema Espainian Marcos Ricardo Barnatánek argitarazi zuela:

"1970ean argitaratu zen azkenean poema, Antología de la "Beat Generation" izenburuko liburu batean. Garaiak aldatuak ziren zerbait: sukaldariak isilagoak egin ziren, atunek ez zioten amuari heltzen jagoitik, oilarren bizimodu arrunta egiten zuten, gazteak dantzara joaten ziren baita udaberrian ere, eta dantzan -hori izan zen gauzarik garrantzitsuena- ordura arte lehenago inoiz entzun gabeko kantak entzuten zituzten: Twist and Show, Qué noche la de aquel dia, The house of the rising sun, Satisfaction, Like a woman, Walking in the wild side, Sitting on the etc, California dreaming, Susy Q... Allen Ginsbergen liburua baino lehen jaldi ziren, eta liburua irtetea bera egin zuten posible. Plater hegalaria lurra hartu ahal izan zuen azkenean"32 (20).

"The howl" poemak gerra ondoko gizarte mendebaltarrarekiko ilusio-galtze kontziente eta antiutopikoaren manifestu unibertsalaren tankera hartu zuen; liberamendu espiritualaren aldeko kantu bihurtu zen, eta gerora liberamendu sexual eta feministako beste mugimendu batzuetatik lerratu eta eskubide zibilen aldeko aktibismoarekin bat egin zuen.

Ezaugarririk nabarmenenetako bat adierazpen librearen mugen bila jotako erronka da, eta aldi horretako idazle ezagunenen testuei darie kutsu hori, bai beren gaietan (drogak, sexualitatea, portaera inzibiko gaitzesgarriak, indarkeria, etab.), bai beren hizkeran ere, non inkoherentzia, lotura gabezia, estasizko enuntziazioa eta, hala berean, hutsaltasuna eta azalkeria elkartzen diren.

Beste alde batetik, gogorarazi beharra dago, kontrakultura gerraondoko bizitza politikoan, bai USAn bai Europan, nagusi zen teknokraziaren aurkako mugimendua izan zela. Theodore Roszak entseiularia, The Making of a Counter Culture: Reflections on the Technocratic Society and Its Youthful Opposition (1968) idatzi zuena, izan zen kontrakulturaren bultzatzaile handienetakoa. Mugimenduak aski garapen intelektual handia iritsia zuen Herbert Marcuse moduko filosofoen partaidetzaz, eta, laster armamendu-lehia eta guda nuklearren problematika

30.- Huncke's Journal (Poets Press, Nueva York, 1965). Editore, Diane DiPrima. Hitzaurrea, Allen Ginsberg.

31.- Hitzaldia osorik irakur daiteke honako estekan: http://www.atxaga.org/testuak-textos/howl.

32.- Marcos Ricardo Barnatán, Antología de la “Beat Generation”, Barcelona, Plaza y Janés, 1970. 
nahiz kontzientzia ekologikoaren lehen zantzuez ohartu ziren gizarte multzo zabalak, bereziki klase unibertsitarioen zati handi batek.

Mugimendu indartsu haren isla modura esan dezagun gaztelaniara egindako Roszacken liburuaren itzulpena, El nacimiento de la contracultura (1970), benetako gertakaria izan zela garai hartako Espainiako panorama politiko eta kulturalean. Kontrakultura, hein handi batean, bigarren mundu gerraz geroztiko gizarte iparramerikarrean gertatu zen desengainu politikoaren seme izan zen. Gazteriaren desenkantua zen, ikusirik politikan benetako ardatz bakarra boterea eskuratzea zela nola edo hala, eta baieztapen horrek berdin balio zuela ezkerrarentzat ere. Pariseko 1968ko maiatz erreboluzionarioko haustura eta zalaparta ere horren adierazpena izan ziren, baina kontrakulturaren baitan iraun egiten zuten analisi marxista eta erreibindikoetako osagai askok.

Beat hitza, John Clellon Holmes deskribatu zuen bezala ${ }^{33}$, jazz musikarako erabiltzen den "erritmoari eutsi" espresioarekin ere lotzen zen, jazzaren ezaugarri erritmiko zenbait baita beat eraginaren pean sortutako poesiaren funts estetikoetako bat. Aski litzateke gogora ekartzea "The howl" izenburua duen Allen Ginsberg poemak lehen formulazio batean oinarritutako anafora paralelistikoa darabilela elementu erritimiko ardatz modura: "I saw the best minds of my generation destroyed by madness".

Poema letania luze baten moduan eratua da, "bere belaunaldiko bururik onenei" eskaini oroitzapenez tartekatua, eta egitura sintaktiko parataktikoa baliatuz osatua. Erraz topa daitezke autore batzuen eta besteen beat obretan erritmoaren garrantziaren isla garbiak, hots, jazz erritmoaren erakusgarri diren errepikapenak, salmodia moduko zerrendatzeak, enuntziaturik osatzen ez duten sintagma zerrenda luzeak... Atxagaren Etiopiako testuetako batzuetan ere badaude era paraktikoan antolatutako koherentzia tematikorik gabeko sintagma homofonikoak, erritmoa sortzea funtzio nagusia dutenak. Horiekin batera (oh year, oh dear, oh baby) pop kantaren elementuak berak ere, Atxagak Ginsbergen ohoretan egindako hitzaldian adierazi zuen bezala, erakusten dute hirurogeita hamarretan itzulitako beat testuak baino lehenago etorri zirela kantak, pop kantuak. Balio beza erakusgarri modura, Etiopiako testu batean "zorionak" anaforak garrantzi berezia hartzen duena honako testu-zati honek:

\footnotetext{
"ta egunero irakurtzen dugu etxe barneko pozaren

hainbat oinarriren izena: Zorionak

jogurt fantastikoekin aurreratuko dugun diruagatik

zorionak zimurrik gabeko arropa horregatik,

zorionak gure esku dauzkagun mila eltzeko misterios

horiengandik, zorionak, zorion beroenak

zorionak for me, zorionak for you, zorionak denontzat.

eta esan zuen Ezra zaharrak aspaldi, klixeak beti klixeak

edo txikleak zapore guztietan, orange, citron

dragon hau baino hoberik ez zagon
}

33.- "un estado mental en el que el ser humano se ha despojado de todo lo innecesario, quedando receptivo ante la realidad circundante, pero a la vez impaciente por los obstáculos triviales" in Marcos Ricardo Barnatán, Antologia de la Beat generation, op. cit., p. 17. 
edo hark esan zuen bezala, bera da politena, asko maite dut o-nou O-nou erantzun zigun Malonek

zerbait egin behar zela eta muturra sartuz

Baionako barraraino

eta nik ere berresan ditzaket zenbait hitz:

etxetik irteterakoan

bide berri edo sekretuen bila ipurdia galtzen zuen gizonaren kasoa

oso gai ona film batetarako

edo hutsala fita doratuko zigarroaren fantasia

Nueva Yorken, eta toki guztietan Nueva York, o-nou

o-nou, zer moduz, comantalevu, eta abar, eta abar".(22)

Poema honetan ikus daitekeen moduan, Pott Bandak eta bereziki Bernardo Atxagaren Etiopia poema liburuak loturak ditu beat mugimenduarekin eta kontrakulturarekin. Horren egiaztapena dira izenburuak hitz-jokoaren bidez (Utopia/Etiopia) utopien amaieraz egiten duen hausnarketa. Hor dugu obran inplizituki dauden kolektibitateari eta haren orientazioari buruzko gogoetak eta bere jarrera pertsonala adierazirik. Miguel Casado idazle eta kritikoak Atxagaren Poemas \& Hibridos testuaz diharduela, beste zenbait testutara hedatzen du eragin beat hori:

"Esta misma trama de lo personal y lo colectivo [de Henry Bengoa inventarium"] se prolonga en poemas como "Crónica parcial de los 70" o "37 preguntas a mi único contacto al otro lado de la frontera" y en todos los demás mitos -como el del ciclista Tom Simpson o el de John Lennon- que circulan por la memoria de muchos, "hechos históricos" en los que muchos participaron, pero también anécdotas mínimas o imágenes simbólicas. Sobre un sustrato beat se yuxtaponen materiales usados y densos, con nombres elementales, como lo pudieron ser los de Gilgamesh o los homéricos"34.

Miguel Casadoren arabera, beat osagaia enuntziazio eta jarrera hartze, aldi berean, dramatiko eta arineko sustratu moduko bat da. Agian, ezer gehitzekotan ere, kritikoaren formulazioari gehi lekizkioke autoreak berak 1996ko Nueva Etiopia ${ }^{35}$ (24) edizioaren hitzaurrean, nerabezaroko kantak gogora ekarrita, esan bezala, The Beatlesak eta haien I'm looking through you (1965) eta Bring it on home to me, Sam Cookeen kantua (1961) zituela gogoan. Sekulako ekaitza sortzen zuten kantak zirela horiek, izan ere, musikak iradokitzen zuen heldu ezinezko misterioa atzemateko desioa pizten baitzuen beragan: mugaz harunzko mundu imaginarioaren deia. Lur ezezagunak begiz jotzeko irrikak kutsatzen ditu, halaber, Allen Ginsbergen omenetan egin hitzaldiaren ildo batzuk, errealitate urrun eta "izugarri" hura

34.- Miguel Casado, "Un lugar al que llamo aquí" Diario 16, "Libros", Madrid, 16-08-1990. Berrargitalpena Apuntes del exterior, Santander, La ortiga, 1999, pp. 95-96.

35.- Nueva Etiopia, canciones, conversaciones y poemas, El Europeo, Detursa, 1996. Atxagaren poema abestuen selekzioa da, Gari, Itoiz, Mikel Laboa, Jabier Muguruza, Ruper Ordorika, Tapia eta Leturiak abestuak. "Presentación" izenburua duen hitzaurreko aipamenak dira artikuluan erabilitakoak (pp. 11-14). 
aipatzen dutenak:

"Todo eso y mucho más era posible en el país sometido a la dictadura del General Franco. Lo que no era posible era la publicación de un poema como "Howl". Pero no únicamente por la censura, como en el caso de los poemas de Blas de Otero; sino por la imposibilidad de que alguien pudiera ponerse en el lugar de Allen Ginsberg o en el de los protagonistas de su poema. ¿Quiénes eran esos grandes espíritus que se arrastraban de madrugada por las calles de los negros en búsqueda de la droga urgente? ¿Qué era la marihuana? ¿Y la mescalina? Ni idea. "Howl" hablaba de otro planeta. De llegar a publicarse, habría sido, en la España de principios de los sesenta, un OVNI". ("Howl") ${ }^{36}$

Pott Bandaren irakurketa Beat kontrakulturan sustraitzea eta harekin lotzeak alderdi interesgarriak zabaltzen ditu Etiopiaren irakurketarako. Erabat koherentea da hori liburuan behin eta berriro hirurogei eta hirurogeita hamarretako kulturaren oihartzunak agertzearekin. Hor dira aipatuak, Caryl Chessmanen epaiketa eta gaseaketa ${ }^{37}$, Sacco eta Vanzettirenak bezain zalantzazkoaren aipamenak, eta heriotza zigorraren kontrako borrokaren ikur bihurturiko presoaren harrizko aurpegia aztertzen duen kazetariarena bezalako narrazio testuak:

"Bere gaseaketaren bezperan Caryl Chessmanen zeldan sartu nintzenean, oraindik ez genekien ziur nola beste gaurik izanen ez zen. Oraindik gobernariak erabakiko zuenaren talaian geunden. Hainbeste urtez betetzeke egondako sententziak esperantzak ematen zizkigun alde batetik, baina bestetik nik behintzat ezin nuen kitatu burutik Sacco eta Vanzettiren kasua, hain paraleloa zenbait puntutan; orain ere jendea barkamenaren alde ari zen kaletan. Baina bestalde maiatza zen, maiatza bere natura eraberrituaren krudeltasunarekin, preso guztiak beldurtzen zituen San Quintineko maiatza." 38 .

Aipa liteke, halaber, Etiopiaren sarrerako narrazio testu bat, "Edonon aurki genezake dramatikotasuna" izenburuko kontakizun laburra, New Yorkeko zinema-areto batean Pazifikoko leherketa nuklearren ondorioei eta faunan eragindakoei buruzko erreportaje baten emanaldia ingurukoa. Ildo beretik doaz poema batzuetako eta besteetako napalmari edo Vietnamgo gerrako gerra kimikoari buruzko aipamenak ere.

Etiopian hirurogeita hamarretako gizartean zegoen kultura zinematografikoa, musika eta soul, jazz eta pop, etab., musiken inguruan etengabe azaltzen den beatak, hutsik gabe

36.- "Howl" hitzaldia in "Homage to Allen Ginsberg".New York, 2006. Irakur daiteke esteka honetan: http:// www.atxaga.org/testuak-textos/howl

37.- Caryl Chessmani eskainiriko poema bat dago Ziutateaz (1976) eleberrian. Novistek ere bat egin zuten beren testuetan heriotze zigorraren aurkako borrokaren sinbolo bihurturiko auzia.

38.- Testuak Chessmanen biografia batetik hartua dirudi, baina identifikatzen ez denez, apokrifoa izan daiteke. Hainbat kazetarik elkarrizketatu zuen 2455 zenbakia zuen bere gela hartan, heriotzearen korridorean. Exekuzioaren bezperan, Chessmanek kazetari lagun bati idatziriko ezagutzen da, San Francisco Examineren argitaratua: "Cuando usted lea esto habré cambiado una pesadilla de doce años por el olvido. Y usted habrá sido testigo del acto final y ritual. Abrigo la esperanza de morir con dignidad, sin miedo animal y sin valentonadas. Tengo respeto por mí mismo. Me siento extremadamente tranquilo." 
erakusten du poesia garaikidearen arrastoa, eta erakusten du, era berean, ordukoz gainditutzat ematen zuen poesiaren ideia solemne eta hizkera goratukoa haustekoa zen lirikaren aldera lerratzen zela autorea. Atxagaren poesiaren sustratu hori finkaturik, Etiopiaren garaikide ziren poeta banguardisten literatur munduarekiko parekotasunak finkatzen ahaleginduko gara, jarraian.

\subsection{Bilbao, hiria}

Obraren sorrerako inguruaren ardatz sozio-politiko, kultural eta literarioak aipatu ondoren, Euskal Herriaren beraren ardatz geografiko eta kultural propioez ere mintzatzea dagokigu. Izan ere, liburua Bilbaon idatzi zen, Euskal Herriko hiri metropoli handienean. Atxaga idazlearen sorrera Bilbon suertatzen da; izan ere, Piolet poetaz eginiko Etiopiako lehen narrazio parodikoan ironikoki dioen moduan: "huritartzearen ondorio artistikoak" aipagarriak suerta baitaitezke.

Ironiak gorabehera, rurala/hiria dikotomiak badu nolabaiteko garrantzia, hiria Etiopiaren genesian elementu klabea den aldetik. Bilbao da liberaziorako aukera sentitutako anonimotasunean birsortu den espirituari aukera eman zion hiria. Asfalto gainean egindako bizitza autonomoa dakarkio Bilboko kaleak. Gero, Gabriel Aresti eta Blas de Otero poetak irakurtzeak bat eginaraziko dio hiriko esperientziarekin: ibiltariak, kalatxoriak, autobus gidariak, kale-garbitzaileak eta zaborketariak, gaueko jaun eta jabeak... Hitz batean, literatura modernoaren ezaugarria den hiri literarioaren bizierarekin egin zuen topo: Beaudelaire edo Rilkeren hiria zen Paris, eta Jon Miranderena. Aldiz, Bilbo zen hiria idazle euskaldunentzat: liluratzen eta beldurtzen duen jendetza, anonimotasuna, bakardadea, nortasun ezabatuak ezagutarazten dizkien hiria.

Jakina denez, Atxagaren produkzioaren lehen partea luzaroan egon da Bilbo hiriari lotua. Bilbao behin eta berriro agertzen da irudikatua Arriaga antzokiaren eraikinaren ondoko zubiaren enbleman; bere obra batzuen liburu-azaletako lehenengoetan, Obabakoak obraren 1988ko argitalpenean bereziki. Antzerki banguardistako lehen obrez geroztik (Puntua eta borobila, 1972), Etiopia arteko bere produkzio guztia Bilbaoko paisaiari atxikia dago bereziki Etiopia. Atxagaren hitzetan esanik, Etiopia "Bilbaoko koadernoa" da: guztiz paisaia berriak eragin dion aldaketaren emaitza. Horregatik bada, Etiopiaren idazketa guztiz "metropolitanoa" izan zela baieztatzea.

Gogora dezagun, dena dela, Guggenheim Museoaren titanioa Bilbaoren irudi modernoaren sinbolo bihurtu baino lehenago eta egin duen berriztapen eredugarriagatik hainbat sari jaso baino lehenago, hiriaren jantziak lainoa eta ibai uherra zirela: grisa; biztanlerik nabarmenenak, berriz, kalatxoriak, eta eskaleak, eta langileak, trafikoa eta ibaia... Hori da Bilbaoren liburuaren muinaren lehengaia. Bereziki dira ezagunak Etiopiaren gune nagusiaren bigarren zirkuluan kokatutako poemak, hala nola, "Orduan arratsero", "Herdoilaren tristeziarekin batera" eta "Kalatxoriak" poema ezagunak.

Bere begiradak, afektuaren kariaz, edertasun malenkoniazko bat hedatzen du hiriaren gainean, Gabriel Arestiren (Bilbao 1933-1975). Ezaguna da Arestik sartu zuela asfaltoa eta porlana euskal poesiako eszenatoki lehen aldiz, modu problematikoan bada ere. Arestiren batera eta haren ondoan beste bilbaotar poeta handia dugu Blas de Otero (1916-1979); biak dira Atxagak hiriaz duen ikuspegiaren oinarri diren literatur erreferentzien sortzaileak. Poeta haietan, ordea, berrogeita hamar eta hirurogeietako poetak diren aldetik, hiria, batik bat, "el 
teatro del conflicto social interclasista" da, klasearteko gatazkaren antzestokia, eta, Atxagaren idazlanean, horrez gain, euskal kulturak bere egin beharreko espazio bizigarria ere bilakatuko $\mathrm{da}^{39}$.

Atxagaren poesiak espazio berritu bat sortzen du; errealismo sozial edo historikoak ez bezalako ikuspegi batetik begiratutako dio ohiko bizimoduaren eszenatoki horri. Izan ere, poemek era bateko eta besteko erreferentzia kosmopolita eta garaikide beatei leku egitearekin batera, jende arruntaren eguneroko hiri bizitzaren poesia sortu zuen:

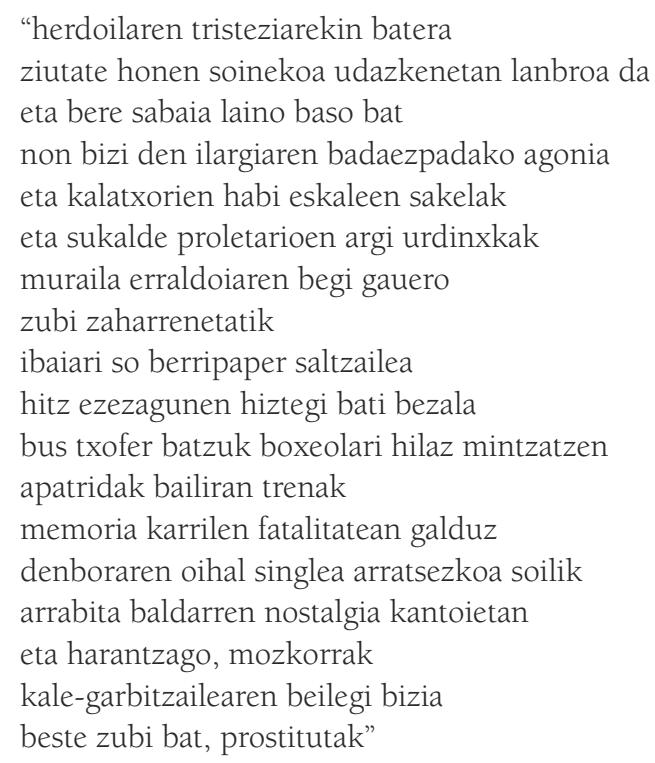

Aztergai hartu dugun Etiopia obraren sorreran dauden aurresuposizio psikologiko, kultural, sozial eta politikoen aurkezpena egiterakoan, poeta gaztea hiri handian azaldu dugu, eta koordenatu orokor gisa hartu dugu trantsizio politikoa eta kontrakulturaren testuingurua.Alabaina, bada oharteman beharreko beste koordenatu soziohistoriko bat ere: Atxagak literatura eta hizkuntza minorizatu batean idazteko hautua egina zuela, herriaren bizitza ofizialaren bazter aski zailean, demokraziarako trantsizio prozesuan dabilen eta, artean, oso katea ideologiko, politiko, sozial eta hizkuntzazko astunak herrestan daramatzanean. Alde horretatik, adierazgarriak dira autoreak Eukal Herriaren errealitate konkretuaz ari dela esandakoak. Izan ere, "egurtuen" bazterketa sozialak hizkuntzaz baztertuei ere afektatzen baitie. Zokoratuta zegoen euskaldun komunitatearen errealitatea ere barnean hartzen zuen:

39.- Aresti eta Atxaga arteko hartuemana laburra, baina emankorra izan zen. Arestik lagundu eta gidatu zuen idazle gaztea. Berez, Pott argitaletxearen lehen egitasmoa T. S. Eliot-en Four Quintetsen itzulpena argitaratzea izan zen, baina zailtasun administratiboek eragotzi zien. Aipamena J. J. Lanz irakaslearena da, "La ciudad de memoria: Bilbao en la obra de Blas de Otero", in Jon Kortazar \& Juan José Lanz (eds.), Unamuno, Otero, Aresti, Bilbao, 2003, p. 85. 
"En mis escritos de aquella época definí, un poco en broma, a todo ese movimiento espontáneo y vital como la rebelión de los pastores, pues hubo un traslado de nuestra lengua y de nuestro mundo a las capitales vascas, que se hizo físicamente durante los años 70. Es una época en la que hay una especie de invasión a las ciudades de los que éramos hijos de los carpinteros o los campesinos que, por primera vez, podían pagarnos unos estudios universitarios. Siempre tuve muy claro que teníamos que conquistar Bilbao. Creo que en cierto modo lo conseguimos, ya que llevamos nuestra lengua del mundo rural a las ciudades y, al mismo tiempo, ésta se prendió de inmediato a la modernidad, lo que evitó que a pesar de ese punto de partida todo esto derivara en una especie de romanticismo o costumbrismo que, desde mi punto de vista, son completamente reaccionarios." ${ }^{40}$

Etiopiako poemen lerroek bere genealogiaren zigilua dute inprimaturik eta modernitatearen esparrua euskaraz eskribitzeko erronkari erantzuteko apostu garbia. Horren sinbolo da "Trikuarena" poema (1988), zeinetan trikuak, euskararen sinbolo bilakaturiko animaliatxoak, bere lurraldean zabaldu duten errepidea zeharkatu behar duenean, bere arantzazko babes zaharraz beste armarik gabe abiatzean auto batek lehertuko duen. Irakurleek berehala ikusi zuten trikuarengan bazterturiko hizkuntzan idazten duen idazlearen parabola, inguruan dabilzkion mehatxu guztiz ezezagunei aurre egin behar dien trikua bezain hizkuntza arkaikoaz abiatzen baita idazlea mundua "esatera", baina hiztegi oso laburrez. "Trikuarena" Etiopia baino geroagoko poema bada ere, ez da ahantzi behar "Pott bandaren braga"(1978) izeneko alearen portadan makinaz idazten ari den triku baten irudia ageri zela, Pott banda izeneko testu bat idazten ziharduena, hain zuzen ere. Irudiak esana zuen geroko Trikuarena poemak adieraziko zuena.

Gure euskal kultura arkaikoak globalizazioaren aurrean, zibilizazio hiritarrera egokitzeko erronka gorpuztu zen, urte batzuk geroago, ezaugarri neobanguardistak nabarmen baretuak zirenean. Animalia bitxia, trikua, bere ingurunean bizi izateko ezin hobeki prestatuta eta ikasita dago. Bere mundua esplikatzeko behar duen hiztegi osoa menderatzen du (jan, ehizean egin, defendatu...) baina erronka handiak ditu orain aurrean, eta hitz asko ikasi behar ditu bizi izateko eta irauteko.

Irakurleek proposaturiko interpretazio modu hori onartu omen zuen egileak, Neuchâteleko Unibertistateak bere idazlanen inguruan antolaturiko Gran Seminairen 2009an aitortu zuenez" . Horregatik, trikuaren aipamena berriro agertuko da "Escribo en una lengua extraña" poeman Nueva Etiopia, (1996) liburuaren sarreran argitaratuan, euskal irakurleek emandako konnotazioarekin. Trikuaren metaforarekin ixten da poema, argi-argi euskal literatura sinbolizatzen duelarik eta, haren historiaren errepaso labur bat egin ostean, amaituz: "El sueño fue largo, la biblioteca breve; / Pero en el siglo veinte, el erizo despertó".

40.- Elkarrizketa. La Jornada, México, 2-02- 2005. URL http://www.euskalkultura.com/noticias/bernardo-atxaga-escritor-vasco-el-euskera-fue-vital-para-una-generacion-de-artistas-y-una-herramienta-de-resistencia-ala-dictadura-de-franco-en-el-diario-mexicano-la-jornada?language_sync=1 Última consulta el 27 de mayo de 2010.

41.- Ikus Andres-Suarez, Irene\&Rivas, Antonio, Bernardo Atxaga. Grand seminaire de Neuchâtel. Coloquio Internacional Bernardo Atxaga. 23-25 de marzo de 2009, Arco, madrid, 2011. 
Euskal literaturaren bizkortzea da trikuaren ernetze hori, literatura berriak protagonizatua. Horregatik, Atxagaren testuetan gure hizkuntzaren eta literaturaren sinbolo bihurtu da trikua, Maria Jose Olaziregi irakasleak "Et...le hérisson se réveilla: passé et présent de la littérature basque" ${ }^{42}$ bere saiakeran dioen bezala:

«Le réveil du hérisson, ce mystérieux animal qui se roule en boule et hérisse ses piquants à l'approche du danger, sert parfaitement à symboliser le développement de la littérature en langue basque. Comme Bernardo Atxaga le suggère dans son poème, il s'agit d'un hérisson qui, après une trop longue léthargie, a heureusement réussi à s'éveiller au XXe siècle. »

\subsection{Neobanguardia eta desenkantua}

1978an Atxagaren liburuak izan zuen harrera kritikoa nolakoa izan zen laburtze aldera esan daiteke isiltasuna, nahasmena eta, aldi berean, jakin-mina eta lilura sortu zituen. Atxagaren obraren efektua beste komunitate eta herri batzuetako irakurleen artean obra neobanguardistek sortzen zutenaren antzekoa zen. Estatu espainiarrean, ordea, ezaugarri bereziak izan zituen neobanguardismoak, izan ere, europar abanguardien eta beat generationen eragina jasotako literatura iritsi zen arte frankismoaren garaiko isolamendu kulturala eta aldi hartako guztiko kultur bizitza apalak markaturiko produkzioa soilik baitzegoen.

Josép María Castelleten Nueve novísimos españoles (1970) antologia ezagunak bildu zituen autoreen ezaugarri neobanguardistak aldi hartako euskal idazleetan ere atzematen dira; izan ere, literatura europarrean dituzte sustraiak. J. Ma Castellet kritikoak bete-betean asmatu zuen Penintsulan sartzea egin zueneko lehen zantzuak igarri zituenean, funtsezko aldaketak antzemanik poeta sozialak deituen belaunaldi poetikoarekiko. Castelletek berak egina zen 1960an einte años de poesía española (1939-1959) izenburuko antologian eta haiekiko aldeak nabarmenduz, belaunaldi berria iragarri zuen: novisimo izendatu zituenak. Gauza jakina antologia hark ezagutarazi zuen novísimos hitza eta 1968az geroztik sortutako belaunaldi osoaren izen bihurtu zuena, besteak beste, Manuel Vázquez Montalbán, Leopoldo Panero, Antonio Martínez Sarrión eta José María Alvarezek osatu zutela. Halaber, beste poeta batzuek ere, hala nola, Félix de Azúa, Pere Gimferrer, Vicente Molina Foix, Guillermo Carnero eta Ana María Moixek ere ezaugarri berak zituztela idoro zuen. Hartara, antologiaren egileak ezaugarri komun batzuk nabarmendu zituen horien guztien poesian: kultura zaharraren aurrean erakusten zuten lotsagabekeria eta fribolitatea eta poesian mass medietako eta popeko erreferentzia hiritar eta kulturalen sartze ugaria.

Hirurogeita hamarretako amaierako poeta novistek lagundu egin nahi zuten diktaduraren krisia areagotzen. J. Ma Castelletek berak aipatu zituen literatur eragile gisa erregimen frankista eta antologia hura horren adierazle zela: "Quisimos decir literariamente que el franquismo se había acabado e incluso que se había acabado aquello de la poesía como arma de combate" (El país, 10-3-2001).

42.- María Jose Olaziregi, «Et... le hérisson se réveilla : Passé et présent de la littérature basque », Lapurdum, 6 | 2001, [En ligne], mis en ligne le 01 juin 2009. URL : http://lapurdum.revues.org/index1208.html. Consulté le 27 mai 2010. 
Idazle neobanguardistek frankismoa ofizialak defendatzen zituen estetika eta etikatik urrundutako poetika erakusten dute, baina bai eta aurreko poesia sozialetik urrundutakoa ere. Novísimoek isolatutako estatuko mugetatik harantzago begiratzen zuten, kosmopolitak izan nahi zuten eta esperimentalistak; estatu frankistaren bakartzeak kultur jarduera ezin urriagoa ekarri baitzuen eta bizitza editorialaren gaineko zentsurak areagotu egiten estankamendua. Hirurogeietan, azken aldera, ingurumari politiko, ekonomiko eta soziala aski aldatua zen, eta hasiak ziren atzerriko testuak ezagutzen, itzulpen hispanoamerikarren bidez batik bat. Espainian argitaratutako "Howl" poemaren lehen itzulpenaz ari delarik Atxagak dioen bezala:

"El editor y el traductor -Marcos Ricardo Barnatán- actuaron con astucia para que aquel aterrizaje fuera suave. Así, en la contraportada del libro colocaron estos versos, quizás los más amables del poema:

El peso del mundo es amor...

no hay sosiego sin amor,

no se duerme sin sueños de amor

sea frío o demencial,

obsesionado con ángeles o máquinas,

el deseo final es el amor...

Los versos también venían en la primera página del libro, acompañados de una cita de Henry Miller a favor de la risa y en contra de la guerra; además, aquel Howl español de 1970 era, en realidad, un fragmento de "Howl". La versión no llegaba a los párrafos donde Allen Ginsberg se refiere a los que repartían "panfletos supercomunistas en Union Square" o a los que follaban hasta consumirse en el éxtasis... una cosa era que los atunes no picaran o que los gallos hicieran vida normal; otra que el Cocinero Mayor y sus censores se chuparan el dedo ${ }^{43}$.

Poeta neobanguardisten arlo tematikoan konpromiso sozialeko poetekin gertatzen den hausturarekin batera etorri zen forma berriagoak hobestea, eta Artearen kontzepzioan aldaketa erabatekoa izan zen, nahiz eta, beste alde batetik, dadaismoaren, espresionismoaren eta surrealismoaren postulatu abangoardistetako batzuei berriro heltzea ekarri zuen. Abanguardiazaletasun horrek sortze lana eta esperimentazioa lotzera daramatza, eta bereziki nabarmenduko da hizkeraren berrikuntzan: Hizkera razionalistak huts egin duela ematen du aditzera, ez dela gauza errealitatea islatzeko; hortaz, hitz poetikoak bere erreferente propioak asmatu behar ditu, errealitatetik haratago. Idazle neobanguardistek unibertso pertsonalak sortzeko joera izango dute surrealismoaren bidetik, zenbaitetan, oso unibertso hertsiak dira, komunikazio zailduz, eta mezua, berriz, lehen poesia sozialean erabateko lehentasuna zuena, bigarren mailara eramanez. Ezra Poundek zioen bezala, ez omen zen jagoitik beharrezkoa

43.- Bernardo Atxaga "HOWL", Homage to Allen Ginsberg, (New York, 2006). Ikus esteka honetan http://www. atxaga.org/testuak-textos/howl. 
irakurleak testua osoki ulertzea, aski zen testuarekin gozatzea eta haren indarra atzematea, edukiaren esanahia doi-doi antzemango bazuen ere. Horregatik, gehienbat testuak interpretatzea ia ezinezko bihurtzen zuen iluntasuna erakusten bazuen ere, konpentsazioan, bestelako edertasun erakargarria eskaintzen zuten testu neobanguardistek, irudien munduaren aberastasunagatik, gaien egunekotasunagatik, erreferentzi segida harrigarriarengatik, collage teknika surrealisten aplikazioagatik, etabar. Bestalde, mundu garaikideko elementuek, hala nola zinemako mitoen gurtza kolektiboak, edota komikietako pertsonaia edo jazz nahiz popari eginiko erreferenteek sentiarazi zieten gazte belaunaldiei indar handiko inarrosaldia sentiarazi zien, unibertso horretakoak zirela berak ere.

Aurreratu dugun moduan, beraz, batzen zituen ezaugarri komun batzuk atzeman zituen idazle gazteongan Castelletek bere antologiaren sarreran. Belaunaldi horretako poeten ezaugarriak ziren, haren aburuz: adina, gerra zibilaz geroztik sortuak izatea, maiatz frantseseko (1968) erreboltak konpartitu izana eta Beat Generationen gogaide izatea, eta haien sloganen oihartzuna egitea euren idazlanetan. Bestalde, horietako gehienek gerren arteko abanguardia europarrekin lotzen ahalegintzen ziren, eta hizkuntza ikertzeko zaletasun berria zekarten; horretarako, kultur tradizio europarretan bilatu zuten inspirazioa irrika handiz. Castelleten hitzaurrearen arabera, interes ideologiko eta jarrera etiko komunak ere bazituzten; eta horren lagungarri izan zuten Marshall McLuhanek berriki "Gutemberg Galaxia" izendatu fenomenoaren eraginaren ondorioz idazleak izatea.

Ezaguna da neobanguardismoak Europan, Alemanian izan zuela sorrera 47 Taldea eta Hans Magnus Enzensberger aintzindari izanik; Frantzian, berriz, idazle neobanguardistek Tel quel aldizkariaren bidez ezagutarazi zuten beren burua 1960az geroztik. Geroxeago, Italian 63 Taldea sortu zen, Novisimi izeneko antologian bilduak ${ }^{44}$, eta azkenaren izenetik hartu zuen Josep María Castelletek 70etako idazle taldearen deitura. Teorikoen iritziz, Neobanguardia europarraren estetikak 1918-1940 arteko abanguardietara itzultzean asmo ideologikoa izan zuen eragile nagusi, hots, sarritan aitortu ohi zaion helburu formal hutsa baino harantzagoko asmo iraultzailea zekarrela. Castelleten antologiarako Vázquez Montalbánek idatzitako sarrerako "Poética" $n^{45}$ adierazi zuen bere estiloaren azalpena ematean, "ergela balitz moduan idaztea" zela bere hautua. Idazteko estilo horren zioa egoera soziopolitikoarekin lotzen zuen. Poesiak funtzio sozial hutsala duela pentsatuta ere, Espainiako literatur produkzioa itotzen zuen zentsura egoerak pentsarazten zion, inoiz izatekotan funtzio sozialik, orduantxe zuela: "cuando cambien las cosas, entonces cambiaré de creencias estéticas" (59 or.) [egoera aldatzen denean, nik ere ideia estetikoak aldatu egingo ditut].

Halere, novisimoen poetika baino, agian gure egoeraren parekoago zen Galizako Rompente izeneko literatur sorkuntzako talde neobanguardista, poesia galego garaikideko proiektu poetikorik anbiziotsuena. 1976an Vigo hirian poesia galegoak berrikuntza poetikoko aldi bati eman zion hasiera jadanik aipatu diren eragin politiko eta ideologiko berrien eskutik.

44.- Honako poeten testuak ziren: A. Giuliani, E. Pagliarani, A. Porta, N. Balestrini y E. Sanguineti.

45.- "Poética", pp. 57-60. "Ahora escribo como si fuera idiota, única actitud lúcida que puede consentirse un intelectual sometido a una organización de la cultura precariamente neocapitalista. La cultura y la lucidez llevan a la subnormalidad. Aprovecho esta oportunidad para pedir una beca estatal por hipersensible" (pag. 59). 
Rompente taldeak, etengabeko abanguardia hartzen zuen ikur eta komunikazio zuzena eduki nahi izan zuen irakurleekin. Abanguardiaren izenean generoen mugak eta literatur arauak urratu eta gainditzea zuten helburu, beren komunitatearen gizarte berritzea sustatuz.

Talde neobanguardistek konpromiso etikoaz eta ikerketa estetikoaz egin zuten konbinazio partikularrak, literaturaren funtzio ideologikoa luzatu eta iraunarazi zuen, baina, aldi berean, abanguardismoaren eta artearen gizarte interakzioaren ikuspegitik formulatzen zuen kontzepzio poetikoa berritzailea izan zen.

Gurean Pott taldeak hartu zuen joeraren ondorioz, obra experimentalok marginalitatean hertsirik geratzen ziren, proposamenak bereziki zirelako ausartak, eta hiper-kodetuak gertatzen zirelako. Bazterreko egoera gainditzeko, ordea, performance ugariez baliatu ziren eta musikaz lagunduta beren poemak abesti bihurtzea izan zen baliabide nagusietako bat. Kantaldi-ererezitaldiekin batean, kultur-etxeetan, institutu eta lizeoetan nahiz pubetan egiten zituzten agerraldi ugariek liburuaz harantzagoko komunikazioko harreman bat sortzea ahalbidetu zuen. Ruper Ordorika abeslariak Atxagaren Etiopiako testuez osaturiko Hautsi da anphora albuma da horren lekuko. Bai eta Henry Bengoa inventarium (1987) espektakulu literarioa ere, non parte hartzen zuten Bernardo Atxaga eta Ruper Ordorikaz gain, Joxemari Iturralde, Alberto de la Casa eta Nando de la Casa musikariak. 'Henry Bengoa, inventarium' 1986 eta 1988 artean errepresentatu zen eta berritzailea izan zen euskal kultur arloan: testuen irakurketa eta musika txandakatzen zituzten eszena gainean hari narratibo bati jarraituz. Berriki Hendaian (2012/12/31), taularatu den literatura-ikuskizun honen berrogeitik gora emanaldiek erakusten dute garaiko euskal esparru kulturalean izandako arrakasta.

John Picchione (2004) ${ }^{46}$ italiar literaturan adituaren esanetan, XX mendearen bigarren erdian Europan izandako eztabaida kulturalik garrantzitsuenetako bat piztu eta bultzatu zuen neobanguardia mugimendu honek. Literaturaren funtzio sozialari buruzko eztabaida berritu baitzuen, eta, partikularzki, literaturak nola bete dezakeen funtzio iraultzailea estetikaz baliatuz, hala nola, testuan kaosa sarrarazita. Picchioneren iritziz, eztabaida horiek modernitatearen eta posmodernitatearen batzearekin dute zerikusi zuzena, kapitalismo berantiarraren testuinguruan literatura kontzepzio globalaren inguruan teorizatzeko azken ahalegina baita ${ }^{47}$ Hipotesi hauxe planteatzen du: idazle novistek poesia disonante, anarkiko bat entseiatzeko asmo garbiaz idatzi zutela, bai europar gerraondoko errealismoaren kontra egiteko, eta bai lirismo zaharkitu, maiztu eta krepuskularraren bukaera zertifikatzeko. Zehazten du, gainera, 1960 eta ondoko urteetako neobanguardia mugimenduak Fenomenologia eta Frankfurteko Eskolako filosofoak izan zituztela gogoan, eta Ezker Berria sortzen lagundu zuten pentsalarien eragina jaso zutela gehienbat. Neobanguardia europarrak, hortaz, desberdintasun garbia dakar abanguardia mugimendu historikoak elikatu zituen anarkia erreboluzionarioarekiko. Izan ere, novistek eszeptizismoa hedatu egin baitzuten utopia sozalistetara eta utopia horien kontraesanak salatzen baitzituzten.

Gogorabedifenomenologiak giza kontzientziaren mugazetaizaera historiaz oharrarazten duela, eta giza kontzientziaren eta hizkuntzaren arteko erlazio erabakiorrari errepararazten

46.- The New Avant-Garde in Italy, Toronto. University of Toronto Press, 2004.

47.- Alfredo Giuliani (ed.), Novissimi. Poesie per gli anni ‘60, Milán, Editorial Rusconi y Paolazzi, 1961. 
diola. Horregatik ez da harritzekoa neobanguardiarentzat funtsezko izatea poesiak egin behar duen hizkuntzaren erabilera kritikoa. Bestalde, praxis politikoa ere eztaidagai bilakatzen zaie, ideologizaziorik gabeko esparru literarioa sortu nahi baitute eztabaida teorikoa egiteko. Atxagaren kasuan aurreko paragrafoetan aurreratu ditugun aspektuak dira horiek eta bera ere ildo neobanguardistaren baitan kokatzen laguntzen digu Picchioneren analisiak.

Literaturak gizarte industrial aurreratuan hartu beharreko lekua da poetika neobanguardista. Ekonomia neokapitalistaren arabera, kontsumitzeko ondasunak gero eta gehiago ekoitzi eta gizartearen zati handiak ondasun horietaz gozatzeko aukera duen gizarte berrian kokatu behar du poeta berriak eta hartaz mintzatu: guztientzako enplegua, etxeko elektrotresnen, ibilgailuen eta aisiaren balizko paradisuan bere ahotsa entzunarazi. Kontsumoaren demokratizazioan oinarritutako ongizatearen hedapen orokorrak utopia teknologikoa kontsagratzen badu, hura salatzea dagokio idazleari. Mundu zaharra abiada bizian ari da galtzen eta aldaketa erabakigarria da: humanismoa iraganeko hondakin anakronikoa da, eta hedonismo kontsumista eta norbanakoen irudi pertsonal eta soziala nagusitzen eta gailentzen. Gizartean gertatu aldaketa horri erantzuteko, neobanguardia poetikoa modelo neokapitalistari irudimenez erasoko dion hizkeraz mintzatu nahian dabil.

Kontrakultura iparramerikarretik eta Neobanguardia europarretik sortutako literaturako ideiak eta haien joerak eta poetikak biltzen dira Etiopian. Ezaugarririk nabariena norbanakoaren zatikatzeak giza kontzientziaren batasun utopikoari uko egitea dakarrela da. Horren isla atzeman daiteke Etiopian, poemategiaren atal nagusiko lehen testuan. Kontzientzia berri horren adirazpena da:

"hi hintzena

bi arraia zaharren gurutzaketa

galdu da, galdu haiz

hautsi da ANPHORA

eta mila ispilutan multiplikatua

ez haiz azken irudi ezabatua baino

ilunaz zipriztinduz bekokia

eta hausterrez

laberintoaren harri txintxarretan

zauritzen hire oin birginak"

Labirintoaren irudiak ematen du aditzera errealitatea deszifraezina dela. Berorren zatikatze konponezinaren kontzientzia hartzen da, behin betikoz etenez historiaren zentzu positibistaren oinarrizko koordenatuekin, espazio eta denbora ardatzetan tinkatuekin. Pichioneren aipamenez ezagutzen dugun Sanguinettiren esanaren arabera, "errealitatea bere dimentsio fenomenologikoan erregistratu besterik ezin dugu egin, objektu, gauza bezala, bere kaosean, bere egoera alderraian edo zero graduan agertuko du poesiak".

Neobanguardian unibertsoa hizkuntz egitatetzat hartzen da batik bat, eta, horregatik, poetikak "ni" erromantikoaren formulazioak gutxitzeko joera erakusten du, ni hori ez da jagoitik heroikoa, ez erreibindikatiboa, ez profetikoa izango, eta, aldiz, poesian bizitasuna, jarduna, dinamikotasuna eta ludismoa indartzen direla ikusten da: kasoaren mugimendutik dator mezua, eta ez haren ordenamendutik. Atxagak Leopoldo María Panero poeta novistaren 
libururako idatzi hitzaurreko oharretan zehazturik egiazta genezake:

"Me imagino a mí mismo allí, en el Borno, ante la roca de L. M. Panero: siento enseguida un zumbido casi eléctrico, el sonido de un enjambre. Y, pensándolo bien: ¿no eran las abejas las que, al decir de los antiguos, servían de mensajeras, las que informaban de todos los sucesos importantes? Piedra oscura llena de palabras, llena de electricidad, de vida." (Ibíd., 11.)

Adierazgarri da Leopoldo María Paneroren (Madrid, 1948) poetikaren sustrai sozialen berri eman zuen "El desencanto" (1974) izenburuko dokumentala, Jaime Chávarrik Panero familiari egindako elkarrizketan agertzen dira idazlearen errebelamendua eragiten duten frankismoko bizitza politiko-sozial eta kulturalak. Hitz batean, espresio literarioa orokorrean bere lexiko eta egitura morfosintaktikoetan eguneratu egiten da. Sintaxiak berak sistematizazio eza eta pentsamenduaren bihurria erakutsiko du aurrerantzean: ez da lotura linguistikoa lantzen; aitzitik, pilatu egiten dira materialak, collage moduan metatzen eta bata besteari itsasten. Edo, parodia, pastiche, etab.etan nahasi bihurtzen dira esaldiak. Poesiaren egiturak eta poesiaren hizkerak kaosa eragin nahi dute, zeren, Sanguinetti hitzez adierazteko "el retorno al desorden es el camino real del retorno a lo trágico"48.

Esandakoaren harian irakur diaiteke Etiopiaren funtsezko testuetako bat, "Berandu dabiltza" (1977), Poemas \& Híbridos (1988) bai Nueva Etiopían (1996) "Crónica parcial de los setenta" izenburu esanguratsuaz argitaratua ${ }^{49}$

eguneroko bizitza ikatza bezalako labezomorroak ixurtzen hasi zenean etengabe, otis redding badiako portuan eseri zen aireplano, jausiei kantatzeko blues band eta panpina amerikanoak lehertzen zitzaizkien vietnamgo umeei eskuetan boom bang, gure amak sabela erre zuen napalmez gauetako tirrinaren amenazoa ezin burutuz sagarraren loreek su hartu zuten eta miranderi odola hasi zitzaion sudurretatik baldosa zuriko komuna publikoetan pornografia irakurtzen ari zenean love darling eta alkimistek txosten bat eman zuten argitara plusvaliaren alde azalduz erabat erre staurantetik bi marikoi bota zituzten arra zoi komertzialak zirela medio eguzkiaren jaki bihurtuko ziren malkoak galdu zituen leopardoak desertu zibilean a bebe bikilak ahaztu egin zuen marathoneko kondaira non dago etiopia galdetuz

Alde batetik, hitz-joko eta gag moduko osagaiz garaiko poesian hizkeraren esperimentazioak zuen indarraren lekuko dugu poema hau eta "anabasa" kalkulatuak iritxi nahi zuen dramatismoaren lekuko eres uma genezake lerrootan. Bestalde, 70etako literatur munduari erreferentziak hainbat dira eta kontsumo gizartearen aurreko jarrera erreboltariaren lekukotza ere nabarmena da. Poema honek liburuan dagoen poesiaren ezaugarri nagusietako batzuk errepresentatzen ditu, eta aipatu ditugunez gain, bere bereizgarri formalak, dira guztiz aipagarri. Esate baterako, puntuaziorik eta letra larririk ez erabiltzea, edota, material, irudi, soinu eta errealitatearen oso arlo desberdinetatik datozen gertakariak erreka erritmiko batek

48.- Kaosera itzuliz, egiazko tragikotasunaren indarra berreskuratuko da]. (E. Sanguineti, Triperuno, Milano, Feltrinelli Editore, 1964. pp. 70 y 88).

49.- 1996ko bertsioan "Ya es tarde" itzuli da. 
bezala eramateak, beat erritmoz blai, energia kaos batek indar eutsiezinez eramanak.

Osagarri neobanguardista karakteristikoenetako bat beste testu zati batzuetan agertzen diren kultura popularraren eta pop kulturaren erreferentziak dira, hala nola, "Barcelona es bona/... si la bolsa sona" bezalako esaera merkeak, kontsumoko objektuen aipamenak (wokswagen, Olivetti), erreferentzia zinematografikoen eta komikien ekarpenak (detektibeak, urtxintxa ebasleak), edo garaiko kezka sozio-politikoak (erreboluzioa, Burtsa, gainbalioa, interes ekonomikoak...), eta horiekin batera literatura aipamenak (adjektibo kalifikatzailea, lehen pertsonak idatzitako poemak, etab.).

Elementu hetereogeneo horiek guztiek hirurogeita hamarretako bizimodu garaikidea erreibindikatzen duen esanahi batik bat sozio-kulturaleko diskurtsoa ehuntzen dute. Ondorioz, poesiaren edertasun eternal estatiko eta estetizatuaren aurka ari da, hurbileko munduaz, konpartitzen dugun gizarte esparruaz eta bizitzaz oso gertutik hitz eginez eta ikuspegi kritikoz. Kontsumoko ondasunen merkataritza sartzen da material arrotz gisa, mintzagai gisa, baina haren presentzia nabarmeneraziz. Nazioarteko jargoi teknikoak sartzen dira, mundu berri horri dagokion erantzuna agertaraziz. Aldiz, desagertu egiten dira gauza zaharkitu eta atzerakoiarekin identifikatzen direnak; nazio bakoizteko literatur tradizioak biribildutako hizkera usadiozkoaren ezaugarriak diluituko dira garai honetan.

"Eguneroko bizitza" eguneroko errealitate kaskarraren adierazpen ironikoa da, eta kontsumo gizartearen aje espiritualaren sinbolo da labezomorro izurritea, ezerk ere geraraz ez dezakeen desegite prozesu bat, dena aldatu nahi dutenek aprobetxatu beharreko izurritea. Helburu erreboluzionario hori autoreak berak adierazi zuen elkarrizketa baten kariaz urte batzuk geroago, hirurogeietako borborraldi artistiko eta kulturala eta erregimen faxistaren zentsura zorrotzaren arteko erlazioa zehaztu zuelarik:

"En aquellos años se creó un movimiento muy intenso, que atribuyo al franquismo, pues hay que tomar en cuenta que el arte moderno perdura en situaciones de dictadura. Dictadores como Hitler o Franco siempre fueron en términos estéticos muy reaccionarios y naturalistas; por eso en aquellos años se debía estar contra Franco y contra estos valores artísticos. Ellos eran reaccionarios y estaban adocenados en el siglo XIX, mientras nosotros siempre aplaudimos todo lo que se saliera de ese tipo de cánones." 50

Zakarkeria dramatiko bat du poesia honek ustegabe zapuztuaren espresiotik datorrena: bizi uste zuen mundua ez dela gehiago lehengoa deskubritu duenaren haserretik, masifikatu eta merkatilizatu egin dutela deritzon munduaren jauste sentsaziotik, desenkantutik, hitz batean. Aldiz, laurogeietako poetak baloreen galera horretara eginda daude jadanik, eta progresua, originaltasuna nahiz etorkizuneko utopien porrota onarturik ari dira, eta postmodernismo ezauagrriak ezarriko dira aurrerantzean. 1978ko Atxagaren Etiopia obrak bikoiztasuna erakusten du biekiko, trantsizio unean kokatzen da: eztanda moduan adierazten den kezka erauntsi bat jasotzen du.

Ezaugarri postmodernoko idazlearen berezitasunak jada agertzen hasiak dira Etiopían

50.- La Jornada aldizkarian argitaraturiko elkarrizketa. México, 2-02- 2005) Euskonews-ek berrargitaratua http://www.euskalkultura.com/noticias/bernardo-atxaga-escritor-vasco-el-euskera-fue-vital-para-una-generacion-de-artistas-y-una-herramienta-de-resistencia-a-la-dictadura-de-franco-en-el-diario-mexicano-lajornada?language_sync=1 
modu gatazkatsuan. Subjektu posmodernoa irrazionalitate afektiboaren menpe bizi da mundu teknifikatuan, historiaren bilakaerari buruzko diskurtsuak sinesteari utzi dio baina ezin du Gianni Vattimok dioen moduan, "inora ez doanaren egoera eta izaera" onartzen ikasi. Etorkizunari buruzko utopiak ezin ditu sinetsi, baina ez daki bizitzen etorkizun hobea desiratu gabe edo hura eraikitzeko ilusiorik gabe. Gizaki posmoderno mota hori bere buruarekin eta bere garaiko emariarekin gatazkan dabil, eta ez da bakana gure poesian ${ }^{51}$.

\subsection{Etiopiako diskurtsu literarioaren kulturalismoa eta pop espiritua}

Mugimendu neobangoardistek berriro dada espiritua, sinbolismo baudelairianoa nahiz eliotarra eta surrealismoaren askatasun aldarrikapena egiten dituzte. Halako moduz berpiztu zen espiritu abangoardazalea, ezen, abangoardiako izarregiko keinu kulturalistak diren epe horretako ezaugarri espektakularrenak, bakarrak ez badira ere.

Neobanguardisten poemetan aipamen eta zehar-aipamen andanak suma litezke, hala egileenak, nola testuenak. Hizkuntza bat baino gehiagotan eginiko aipuez gain, pintore, zine zuzendari eta aktoreen erreferentziak sarrarazten ziren, glosa eta aipamenak egiten ziren testu literarioez, bai eta kultuko idazle minoritarioenak ere. Ordura arte ezagutu gabeko idazle izartegi zabala eskaintzen zioten irakurleari.

Kulturalismoak hitz poetikoa gurtzen du eta poetaren mundu propioa, bere munduaren ikuspegi intimoa kodetzen du idazleen testuetan zehar, sarritan irakurlearentzat irakurgai kriptikoa bilakatzeraino. Poetaren barne mundu urratua oso zeharka ematen da aditzera, erreferentzia eta haustura logikoen bidez, Freudek "huts egindako egintza" zeritzenak imitatuz. Horrela, azkenean, poetaren identitatea galdu, hautsi egiten da, hizketari ezaugarri fragmentatuak emanez, gaiaren batasun logikoa sakabanatuz eta esanahia dramatikoratz lerratuz ${ }^{52}$.

Ezaugarri kulturalistak, Europan neobanguardiako literatura orotan agetzen direnak, Etiopian ere presente egon ziren, idazle zerrenda luzea biltzen baitu aldez aurreko epigrafeetan aipaturik, zuzeneko aipuetan, etab. Aipatzen diren idazleen artean nabarmendu ditzakegu, besteak beste, A. Cravan, G. de Nerval, F. Pessoa, R.M. Rilke, S. Beckett, A. Rimbaud, Giuseppe Ungaretti, Giacomo Leopardi, euskal idazleak ere tartekatzen direla, hala nola, Esteban Urkiaga Lauaxeta, Xabier Lizardi, Jon Mirande edo Piarres Topet Etxahun, pintoreak: Francis Picabia edo musikoak, Otis Reading o Lou Reed..., besteak beste.

Erakustaldi kulturalista horrek ez zuen helburu, izen handiko kultura balio eternotzat goraipatu edo konsagratzea, guztiz bestela, kultura hori nabarmenki "bistaratu" eta "arrotz" ikusarazi nahi zuten; izan ere, neobanguardisten obrak kokatzen ziren kultur inguru bakartu eta beren garaiko nazioarteko kulturarekiko loturarik gabekoa nabarmenarazi nahi zuten.

51.- Dionisio Cañasen "El sujeto poético posmoderno" in María José Rodrigo Mora, Ínsula,1989, 512-513, pp. 52-53.

52.- Hona hemen poeta novisimoen zenbait baieztapen adierazgarri: Luis Alberto de Cuenca, “(...) glosar es hoy la única actividad creativa -en lo literario- que me parece honesta y divertida. La tan buscada originalidad es una fábula sin el menor sentido, torpe y vulgar" (Scholia, Barcelona, 1978, pag. 7). eta Pere Ginferrer: "No nos apetecía escribir nada que no tuviera unos orígenes culturales, librescos. La vivencia (esa horrible palabra) sólo venía después, a impedir que el plagio fuese perfecto." (Poesía, núms. 5-6, 19791980, pp. 245-251). 
Kulturak bereizi eta desberdin baloratu ohi dituen materialak nahasten zituzten kultura elitista eta "sublime" aren goi mailako aldareak beste sortzaileen parera ekarriz: idazlerik finenak, atzerritarrak eta bertakoak ekartzen zituzten, herri kulturaren mitoak eta beat mugimendua, jazz, blues eta pop erako musika hiritarraren sortzaileekin elkartuz: Lizardi Rimbaudekin, Etxahun Mirande edo Lou Reedekin.

Aurreiritzirik gabeko estetika garaikidea errebindikatzen du Atxagak Etiopian. Atxagaren poemetan modernitate hiritar eta garaikideko pertsonaien aipua egiten da, "Berandu dabiltza" poeman ikusi ahal izan dugun bezala. Haren iruditerian bizi dira zinema eta komikeko pertsonaiak, mass medietako kultura, irratia, makina txanponjaleak, filmak, Humphery Bogart, Bonnie and Clide, King Kong, detektibe filmak, "elemental Mr. Watson" eta filma beltzetako neska fatalak "urre-koloreko ahoko zigarretak" fumatzen eta atzealdean marra duten kristalezko galtzerdiak jantziz. Horregatik esan izan da pop literarioa iragartzen duela liburuak euskal literaturan, masa komunikabideen eta zinemaren kulturaren eraginaren aitorle delako.

Alde batetik, kultur erreferentzia ezin zabalagoa errekonozituz konplizea den irakurle eskatzen du, baina bestetik, hizkera metaforikoaren hermetismoak eta monologo poetikoa garatzen testuinguruaren elipsiaren erabilpenak planteatzen dizkioten erronkei erantzuko prest dagoena ${ }^{53}$.

Bestalde, eguneroko hizkeraren desmitifikazioan dihardu idazleak, nahita erabiliz leku komunak, esaldi eginak edo utzikeriaz kontzienteaz idatziz ${ }^{54}$. Egiazta dezakegu desmitifikazio hori "Francis Picabia" edo "Berandu dabiltza" izenburuko poemetan. Gutxiago aztertu den beste poema bat aipatzearren, "Orduan arratsero" izan daiteke egoki adibide gisa: mila aldiz errepikatutako esaldiaren poderioz topiko bihurtuak desautomatizatuta geratzen dira beren ingurua deliberatuki "oharkabean" higatuta. Beren balio eternoa berreskuratzen dute eta hitzek berriro beren egia esaten dute. Lerro bakar batzuk aipatze aldera, amodioaren aurkitzea iragartzen duen poematik har genitzake, "Arratsero urreztatzen zen ibaia" incipit duena. Amaitzeke uzten duen adierazpenaz bukatzen da, aipamen literario bat sartzen duela:

\author{
"udazken hartan izen ugariko emakumea bihurtu hintzenan \\ Casiopea eta Pollux edo Isis and Pandora eta Bereniceren \\ ilea, elemental Mr. Watson \\ astelehen edo astearte batean, gogoa higan nuela, \\ nire sexuan aurkitzen dun Bagdag \\ nire zerebroan hazten ditun Kanadako basoak \\ idatzi ninan gauez \\ baina hi basorik arbatsuena. \\ orain hire maitale traketsa naun \\ maitatzen haunat negu bezperetan etcetera etcetera"
}

\footnotetext{
53.- Ikus Javier Letrán, La poesía posmoderna de Luis Alberto Cuenca, (Madrid, Renacimiento, 2005) eta Juan José Lanz Introducción al estudio de la generación poética española de 1968. Elementos para la elaboración de un marco crítico en el período 1962 1972, Bilbao, Universidad del País Vasco, 2000, bereziki Scholiari buruzko orrialdeak, 395-396.

54.- José Ma Castellet, Nueve novísimos españoles, Barcelona, Barral, 1970, p. 44.
} 
Poemas \& Híbridos liburuari egin iruzkinean Miguel Casadok honela eman zuen aditzera bide Etiopiako hizkeraren erabilera hain bereziaren gakoa:

"Para que la lengua pueda mostrar al tiempo ese haz y ese envés no ha de reproducirse ella misma como tópico; la tarea de limpieza en el lenguaje corre a cargo aquí de las referencias a la vanguardia -Dadá, creacionismo- y a lo infantil: limpiar la voz y los ojos, hacer un silencio -de la literatura y de la cultura, de la retórica- desde la que sea posible hablar y ser oído." ${ }^{55}$

Horra beraz, abangoardia dadaistaren ekarpen gisa kulturaren erretorikatik arintzea eta isiltasun gunea sortzea, hitzek berriro beren adiera eta purutasuna berreskura dezaten. Atxagaren poemak ironia eta haustura logikoa baliatzen du horretarako: bere maitasun adierazpena egin ahal izan dezan eraginkortasunez, lehen adierazpen hiperbolikoak modu kritikoan oroitzen ditu, baina ondoren aitortzen egiarekiko leialtasun osoa: "maite haunat neguaren atarian, etc.", bere zentzu osoan berrindartuta, behialako deklarazio haren zehar aipamen "nekatua" indarberritu eta berme osoaz adieraziz. Bestalde, azken "deklarazio" horretan bezala, diskurtso zehatzaren erlatibizazio etengabeko batekin egiten du topo irakurleak. Hainbat osagai morfosintaktikok sarrarazten dute desoreka hori: zalantza adierazten duten adberbioak (apika, behar bada, agian,...), denboraren zehaztasunik eza (arte oro, zenbait arrats) edo aditz hipotetikoak, eten hastangarriak, prosako parentesia eta sintaxia abarretan luzatuz baieztapenak, batean bai eta hurrengoan kontrakoa esanez, arestian esanikoa arindu nahian edo indarra eta balioa mugatu nahian, eguneroko hizketa desautomatizatuz, bere asertibitatea galdera ikurraz markatuz.

\subsection{Antzerki abangoardistaren jarauntsia}

Idazlearen ibilbideari bagagozkio, abanguardiako antzerkiaren eraginak sakon errotuak dira 70ko bere idazlan guztietan. Ez dezagun ahantz Atxagak "Puntua eta Borobila" (1972) argitaratuz eman zuela ezagutzera bere burua autore dramatiko gisa, eta enuntziazio modu dramatikorako interesa oso agerikoa dela 1976ko Ziutateaz bere nobelan ere. Abanguardiako antzerkia izan zen bere laneko literatur tailerra, eta partikularzki, hastapeneko idazlan atxagatar gehienetan igar genezakeen Bertolt Bretch-en poetika zindoaren eraginaren ostean, Alemaniako antzerki espresionista ere oroitzea komeni da. Brecht presentzia handiko egilea da trantsizioaz geroztiko euskal lirikan eta Atxagak ere artearen lehentasun etikoen planteamenduek ez dute huts egiten haren adierazpen guztietan. Nolanahi ere, Atxagaren lirikak hizkera teatraletik hartuak dituen oihartzunak gehiago lotu beharko genituzke expresionismoarekin, izan ere, Ziutateaz (1976) eleberrian txertaturiko osagai dramatikoetan gardentasunez ikus daitekeen bezala, gizakiaren buruan gordeak diren alderdi bortxazko eta groteskoen ikerketan baitihardu lokamuts giroko eszenetan islatzen duelarik. Distortsioa eta gehiegikeria, irudi bortitz etaa fragmentatuez baliatzen ziren Georg kaiser edo Erns Toller dramaturgoen lanetan mamitu zen expresionismoa. Baina are ziurtasun gehiagoz lot genezake Hirurogeitako hizkera dramatikoa Antonin Artauden obrarekin.

55.- Miguel Casado, "Un lugar al que llamo aquí" Diario 16, Apartado de "Libros", Madrid, 16-08-1990. Berrargitaratua: Apuntes del exterior, Santander, La ortiga, 1999, pág. 96. 
Artauden antzerkiaren teoriatik datoz Atxagak hirurogeitamarretan zituen ideia literario batzuk eta bereziki Krudeltasunaren Antzerkia da bere abanguardiako poetikaren erreferentzietan bat. Artaudek zioenez, antzespenak zitekeenik eta eraginik handiena egin behar zuen ikus-entzuleengan, eta horregatik erabiltzen zituen argi, soinu eta exekuziomodu txundigarri eta asaldagarriak. Izurriteari buruzko produkzio batean, adibidez, hain soinu errealak erabili zituen, ikus-entzuleen arteko batzuei oka eragin zien ikuskizunaren erdian. Le Théâtre et son Double (1938), bi manifestuz osatutako beren liburuan formulatu zuen «Krudeltasunaren Antzerkia». Haren iritziz, sadismoa eta oinazea sortzea ez ziren krudeltasunaren ezaugarriak, aitzitik, errealitate faltsua suntsitzeko erabaki fisiko biolento batez ari zen jokatzen bere lanetan. Horregatik, Artaudek "krudeltasuna" diziplina modu bat bihurtzen du, "formak arbuiatu eta behar zuen kaosera bultzatzeko" (Jamieson, 2007:22) Artaudek jaso zituen eragin estetiko eta ideologikoen artean dadaismoa dugu. Haren proposamen osoa bizitzaren eta artearen ikuspegi antiburges horiek ukitua da. Gizartearen eritasuna diagnostikatu zuen, eta ezaugarri erritualeko antzespen esperientzia batetik abiaturik sendatu beharra: artea eta bizitza idenfikatu egiten dira konbentzio tradizionalen hausturaren bidez. Artauden antzerkiari buruzko ideietan, arrazoiaren baldintzapen gezurtirik gabe, inkontzientea eta egia soila, egia inkontzientea argitara dadin ahalbidetzen duten automatismoak aktibatzen ditu krudeltasunaren antzerkiak ${ }^{56}$.

Etiopiako elkarrizketa dramatikoen gisakoek ere, osorik edo zatiz, "istorio" bat dakarte gogora ahots desberdinen bidez. Etiopian elkarrizketa dramatiko horien adibide bat Fas fatum poema da, zeinetan batzuen eta besteen oharrek, pertsonaien ildoek bat egiten duten:

\author{
fas fatum ene lagunek fadoa \\ zein tristea den diote \\ moito obrigado \\ entzuten da bazter batetik \\ 53 urteko gizonak lan ezan \\ badu gidatzeko dokumenta \\ edozein lan hartuko luke \\ premia larrian \\ behar bada \\ dagoenerako bota du burua dio \\ ( maite haunat) \\ bota ditu koilara, ezpata \\ faloa esan nahiko duzu
}

56.- "The Theatre of Cruelty means a theater difficult and cruel for myself first of all. And, on the level of performance, it is not the cruelty we can exercise upon each other by hacking at each other's bodies, carving up our personal anatomies, or, like Assyrian emperors, sending parcels of human ears, noses, or neatly detached nostrils through the mail, but the much more terrible and necessary cruelty which things can exercise against us. We are not free. And the sky can still fall on our heads. And the theater has been created to teach us that first of all" (Lee Jamieson, Antonin Artaud: From Theory to Practice, Greenwich Exchange, 2007, 23. orr.) 
( nik ere maite haut)
utzi du betiko leihoa
eta bildu zaio odola urarekin
arrazoina daukan
1 menturazaleen sasoia amaitu den
3 lurrak orain ere
infinituak ditun haur-oin tipientzat
2 eta atzo bezala esnezko ibaiak
obsesiboki begetalen azpietatik
4 baina non dira heroiak
5 imajina ezina dun beste Lope Agirre bat
6 gau zomorroen gisa akabatzen gaitun
7 gure azken orduak:
8 lore zimelduen inpalagoa
9 asfixia
9 zikina aurkitzen dinagu krobitxeta
9 konjeladore made in Germany horretan

Marra ilun, krudel eta nihilistako gogoeta bat da langabetuari buruzkoa, zirraratu nahi duen gogoeta, kontrapuntu gisa jokatzen dutelarik, tabernako lagunen elkarrizketa axolagabeak eta maitaleen adierazpenek. Ordea, iraultzaren ezinezkotasuna, asfixia eta inpotentzia gailentzen dira poema honetan. Etsipen gogor batek zeharkatzen du lore zimelek eta gorpuak estaltzeko krobitxeta zikinak iradokia, lore zimelduen usai gozo-ustelak iradokitzen dute gorpua, modu traketsean hildakoaren abentura zoritxarrekoa adierazten du eufemismoak: "bildu zaio odola urarekin".

Baina "Fas fatum"eko bakarrizketa gurutzatu eta dramatikoen ordez, beste poema batzuetan gerta daiteke krudeltasun hori itxura batean arinki tratatzea ere. "Lauaxeta gogoan eta begien omenez" poeman autoreak gogoeta eginarazi nahi du Lauxeta poetak behiala defendatutako ideario abertzalearen inguruan, arinkeria krudelaz errugabeei, haurrei eta Lantainaren alabari, egindako mutilazio fisikoak aipatuz. Helburua irakurlea asaldatzea, iharrostea $\mathrm{da}^{57}$.

Lauaxeta gogoan eta begien omenez

bi haur hil - ditugu - gaur

( hil hil hurra )

eta itsasoak eta panterak persekutatzen

bete ditugu geure azken mendeak

(urte oro, zenbait arrats )

57.- Lantaina da Urtsuaren etxea. Balada tradizional batean Lantainaren alabak bere aitarengatik egiten du negar, bigarren emazteak hil baitu. Bidegabekerien aurrean etsitzen ez dutenen ahotsa errepresentatzen du. 
Lauaxeta gogoan eta begien omenez

fortunaren karroza beltza erre ondoren

( Urtsuara abiatu gara)

Urtsuan titiak

ebaki dizkiogu Lantainako alabari

( bi heriotza fruitu bailiran)

eta Lauaxeta gogoan bi zuhaitz gazte

landatu ditugu haren ninietan

Krudeltasunaren antzerkiaren eraginak dadaismoarekin eta nihilismoarekin elkartzen ditu Atxagaren idazlan honetan Leopoldo Paneroren liburu baten hitzaurrean esan zuen moduan $^{58}$

“... como los poemas de este libro, expresarían desesperación, una visión tanática de la existencia, una dura tristeza; como si, además de estar condenado a vivir, estuviese también, nuevo Sísifo, condenado a llevar la roca pero que, a pesar de ello, sus marcas -sus rayas, sus estrías- indicarían una gran viveza, un dinamismo y una agilidad poco comunes; una extraordinaria salud (p. 11).

Lerro esanguratsuak dira goiko horiek, zeren Ezra Pounden poetikak eskatzen zuen bezalako irakurketa dadaista egiten baitu Atxagak, ez du testuaren esangura semantikoa bilatzen, aski baitu haren energia atzematea: dinamismoak mintzatzen du indartsuago testuaren beste ezein osagaik baino. Bestalde, garrantzitsua da egileak Panerorengan aurkitzen duen jarrera tanatikoaren aipamena, Etiopiako literaturan ere badagoenez, eta indarrez adierazia. Pultsio tanatikoak, Freudek ezagutzera eman bezala, subkonszientearen ekintza autodestruktibo multzo bat izendatzen du. Jokabide eta jarrera horiek norbere buruaren suntsipena dakarte, alkohola edo bestelako drogen kontsumoaren ondorioz, edo gehiegizko etsipen filosofikoaren eta autokritikaren ondorioz. Modu horretan, niaren adierazte mailarik baxuena bilatzen du. Desparadisu etiopiarreko testuen irakurleak ere sumatu du pulsio hori, izan ere, testuetako arlo lexiko-semantikoan berehala nagusitzen dira desesperazioarekin edo barne-erredurarekin lotzen diren ekintzak, hitzak eta irudiak. Are gehiago da hori nabarmena egilearen eskuizkribuen dossierrean ageri diren bazter oharren ildoa jarratuz gero. Esate baterako, "Abiatu zara, bazatoz Etxahun", zortzigarren zirkuluko poemaren oinean ikus genezake "bernardo atxaga, abuztu inmiserikordean.77".

Etiopiaren liburuaren lehen eskuizkribuaren dossierrean diren testuen eskuizkribuetako zenbait oharrek aditzera ematen dute poemategiaren atal batek behintzat honako titulu hauxe zeramala, "Erretzen (fumatzen?)". Lau testutan gutxienez ageri zen, zenbakiez lagundurik.

58.- Leopoldo María Panero, Danza de la muerte, Tarragona, Igitur, 2004. Prólogo de Bernardo Atxaga "Poeta maravilloso", pp. 9-11. 
Zalantza gutxi da paratestu modu horrek areagotuko zukeela testuaren ildo expresionista, euskarazko erretze eta fumatzearen arteko gag-a izenburura eramango luke: erretzen anbiguoa, polisemikoa da euskaraz, fumatzen berriz ez. Horregatik, esanahi jokoak irribarrea sortzea du helburu, irribarre krudela, izan ere oso ezberdina baita norbera erretzen egotea ala pipatzen, hots, zigarroa fumatzen egotea. Bestalde, garbizaletasunaren arbuio eta parodia ere izan daiteke izenburu hori: erretzen ari zara, ala zigarroa fumatzen ari zara?. Azkenik, esangura iraultzailea ere funtsezkoago izango zatekeen izenburu horren ildotik, izan ere, "Ez nau emaro iragan" poeman dioenaren arabera, egileak barrena "sutan", erretzen sumatzen zuen:

"Suaren derrota oroz elikatzen naun.

Besteak formolean eta ni gorrotoaren baitan

Eta nirekin mitxeleta guztiak mitxeletak, mitxeletak." (Etiopia, 1983, 72).

Ildo honexekin egiten du bat abesti-testuen egile moduan Atxagak eginiko 1977ko kantu baten testuak ere: "Gure herria" du izenburua eta Iñaki Eizmendi abeslariak Gureak ez diren kale ixileen bi milagarren samiña izeneko LPan grabatua zuen.

Gure herria andere zabala da

morez jantzitako andere zabala

bere zainetan odola

gasolinaz nahasten da

bere bularrak bi botila

bi botil berde dira

eta hoietako egunen batean

suak pizten direnean

bere bihotza molotov

molotov koktel bat bezala

hautsi eta

lehertuko da.

Eizmendiren LPa eta Atxagaren Etiopia Jose Manuel Susperregi argazkilariaren lanaz hornitu ziren azal eta barne: zuri beltzeko argazkiez. Taxuera batek elkartzen ditu bi lanok, lotura musikal horrek rock and roll musikaren esparrura garamatza, Iñaki Eizmendik 70eko hamarkadan zehar Ez dok hamairutik aldentzen ari ziren kantari berrien arteko zubian kokaturiko kantuak egin baitzituen, hiri giroko istorioak kontatzen zituen testuak abestuz. Eizmendiren testuen artean, erradikalagoa da Atxagaren "Gure herria" testua ere, agian harrigarriki gogorra eta ausarta ere bada mezu asaldatzailearen adierazpen gogorra. Izan ere, errealitate faltsua suntsitzeko erabaki fisiko biolento batez ari zen idazten Atxaga, poesiaren hizkerari bizitza apasionatua eta ernaia berriro itsasteko bidea hautatu du. Izan ere, Artauden abiapuntuko hipotesia baitzen arte guztiek bizitzaren oinarrian dauden basakeriak islatzen eta 
areagotzen dituztela, esperientziaren emozioa birsortzeko helburuz ${ }^{59}$.

\section{ATALA: AZTERKETAREN MAILA SINTAKTIKOA}

Lanaren bigarren atal honetan testuaren beraren gauzatze edo mamitze prozesuari dagozkion alderdiak aztertuko dira. Horretarako, lehenik enuntziazio modu lirikoaren aniztasuna eta monologo dramatikoaren ezaugarriak azpimarratuko dira, maila morfosintaktikoaren arloan nabaritzen den fragmentarismoarekin batean.

\subsection{Etiopiako ahots lirikoaren aniztasuna}

Poemaren alde enuntziatiboak garrantzi handia du testuaren modu lirikoa definitu behar dugunean eta aurretik aipaturiko dadaismoaren enuntziazio askatasunak esperimentaziorantz daramala egilea. Obran erabili diren era enuntziatibo desberdinek eta horien ezaugarriek hain dute traszendentzia handia, ikuspegi semiotikotik begiratuta, autokomunikazio lirikoak suposatzen duen kultur fenomenoa ederki agertarazten baitute. Genero lirikoan espezializatutako bibliografiak aldi orotako lirikaren berezitasun enuntziatiboak nabarmentzen dituenean, partikularki azpimarratzen du diskurtso lirikoaren izaera zirkunstantzialean erabakitzen den ahozkotasuna eta idazketaren arteko tentsioa. Izan ere, poesiak erreferente zehatzik gabeko hemen, orain, $z u$ batez baitihardu; horregatik eskatzen dio irakurleari jarrera enpatiko ernea, poemaren irakurketarako testuingurua sortzeko, testua kronotopo batek zehaztutako egoeratik jaregiteko eta irakurraldi bakoitzean berkokatzeko. Cabo Aseguinolaza eta Maria do Cebreiro Rábadek (2006) laburbiltzen duten bezala, lirika deritzogun generoan oinarrizko baldintza da egoera komunikatibo birtual batean, fikziozko egoera batean kokatzen direla enuntziazio-egilea nahiz enuntziatarioa edo diskurtso horren hartzailea, eta ondorioz, poetaz beste norbait den ni poetikoak esaten du poemak dioena eta irakurlea ez den enuntziatario bait zuzendurik doa ${ }^{60}$.

Igorlearen eta hartzailearen arteko komunikazioko "jarrera liriko" posibleez Wolfgang Kayserek proposatu diseinu tipologikoa hartzen bada gidaritzat, Etiopian diskurtso poetikoa bideratzen duten ahots ugaritasunarekin egiten dugu topo, fikzioetan ohikoa den polifonia ezaugarriez bestelakoa imaginatu oih da lirika genero monologiko gisa, baina liburu honetan diskurtso enuntziatzaile ezberdinak entzuten ditugu, hartzaile ezberdinak eta hartara poesia liburuaren fragmentarismo sentsazioa areagotu egiten da.

Lehen-lehenik, enuntziazio-moduei erreparatuz gero, hirugarren pertsonan eginiko enuntziazioa genuke nagusi, ni lirikoaz kanpoko errealitate bati buruz diharduen enuntziatzaile-narratzaile bat. Testuaren hartzaileari egiten zaio deia aipatu gabe, biak ere testuan jasotako gaietako emozioarekiko loturarik gabe daudela. Hastantze jarrera lirikoaren adibide dira "Esploradorearena", "Herdoilarena", "Izen eta data ezezagunez" edo "Kalatxoriena" modukoak:

59.- Lee Jamieson, Antonin Artaud: From Theory to Practice, Greenwich Exchange, 2007.

60.- CABO ASEGUINOLAZA, Fernando y RÁBADE VILLAR, Maria do Cebreiro, Manual de Teoría de la literatura, Castalia, Madrid, 2006, 285. 


\section{kalatxoriak \\ bere maitasunak errepasatzeko \\ hiriko kalatxoriak \\ arratsero biltzen dira estazio aurrean;}

Bigarren jarrera lirikoa apostrofearen gisakoa da, non hartzaile aldaketa ezustekoa gertatzen den, testuan nor den agertzen ez den "ni" bat mintzo da, bigarren pertsonaren erabileran islatzen den "zu" edo "hi" bati ari zaion. Enuntziazio jarrera modu hori hainbatean ageri da Etiopian, batik bat hartzaile fiktizioa konplizea denean, edota afektuaren objektu denean. Horien artean dira aipagarri "Orduan arratsero", "Fas fatum", edota "Jarri zara bidean, Etxahun", Ildo honetakoa da, era berean, "Lizardi", petit poetari eskainitako poema, elegia bitxia, edo maitasun poema zenbait ere bai, hala nola "Hutsalak my love".

"Ainhoa" neskatoari zuzendurikoa izan daiteke adierazgarriena, non enuntziazioa deiki maitekorrez, gomendio txeratsuez gozatzen den, inola ere lortu ezinik entzunizazio liriko horren bitartez poemak daukan eduki malenkoniatsua, izan ere, etorkizun ez hain gogoa iragazten baitu neskatxarentzat, inola ere ez begiratzeko esaten dion masusten zaporea bezain gozoa:

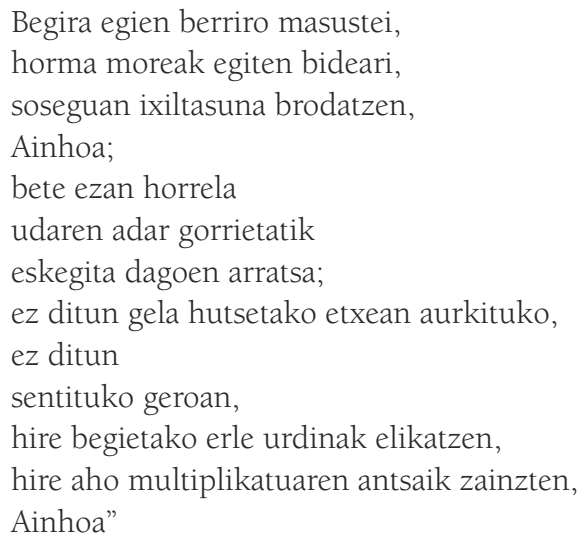

Hirugarrenik, kantu-hizkera ere badago testuan, lehen pertsonaren erabileran islatzen dena, funtzio espresiboa nagusi den testuetan. Etiopian lehen pertsona singularra beti elkarrizketakide bati, zu edo hi bati zuzenduriko poemetan espresatzen da, monologo dramatikoaren eran. "Ez naun emaro iragan" poema izan daiteke horren adibide, non Ama eta Arreba izendatzen dituen errautsa edo sugea bezalako "konfidente"ei eginiko adierazpen intimistak aurkizten diren, Ziutateaz (1976) liburuko poemen ondorengo nabariena dena Etiopian:

Zaldi bulartsuenaren taupadak ur tanta baino ez Ene bihotzerako aduana pasatzerakoan ilunetatik A rreba e rrautsa sinistaidan, desioa dun nigan. Suaren de rrota oroz elikatzen naun. 
Aldiz, lehen pertsona pluralean aurkezten denean, hala nola, "Eguneroko bizitza" izenburuko testuan, "gu" kolektiboan babesten da subjektu lirikoa, eta askoz kementsuago ageri da, taldearen indarra bilzten du eta gu horretan biltzen ditu ideologikoki kide dituenen arrazoia defendatzen duten testuak. Ez da harritzekoa, beraz, bere belaunaldikoen kronika egiteko hautatu zuen enuntziazio modu horrek manifesto baten izaera hartu izana, besteak "Berandu dabiltza"la esanez izenburuan,

"Baina alferrik zen berantzu dabiltza ez dute ezer lortuko honezkero palazioak lurrera doazenean pitzatu egiten dira gartzeletako hormak. Eta gu libro gabiltza kaleetan tirantezko galtza laranjaz jantzirik, libro, libro"

Hiru enuntziazio modu hauen bidez polifonia lirikoari bide ematen dio Etiopiari. Arcadio López-Casanovak (2007) Macrotexto poético y estructuras de sentido. Análisis de modelos líricos modernos tratatuan, poesia garaikideko beste aukera enuntziatibo batzuk ere definitzen ditu, Kaiyserrek zedarrituriko hiruez gain. Honako modu liriko horiek "bikoizte" edo desdoblamentuek dakartzaten nortasun-jokoen bidetik doaz. Casanovaren esanetan "hastantze bat sortu" nahian erabilitako prozedura da bikoizte hori. Ni-a zu edo hi-an bikoizten da, Etiopian oso presente dagoen ni-aren barneratze-prozesuaren adierazle gisa. Hala, hi dioenak ni esaten du: "hi hintzena/bi arraia zaharren gurutzaketa/galdu da, galdu haiz/hautsi da ANPHORA".

Gisa berean, gertatzen da bikoiztea lehen pertsonaren mozorroa den hirugarren pertsonaren bidez aditzera ematean ere: Esploradorearena deritzan testuan ikus daiteke: "Esploradore nekatu batek zer ikus lezake/ tristeziaren metro koadratu baten mugetan/ limoiondoz inguraturiko kaminoak ezpadira"

Poemategiko ahotsen polifonia, beraz, enuntziazio pertsonen alternantziarekin bidez lortu da, ni, hi, gu, zu, hura eta aipatu ditugun bigarren eta hirugarren pertsonen bikoizteekin. Baina polifonia hori ez da kaotikoa Etiopian, bereziki nabarmena baita polifonia horren atzean sumatzen den ahotsa kontzientzia bakar bati dagokiola, modu dramatikoan ahots diferenteen bidez espresatzen dena, drama baten entzuten diren ahotsen gisan. Hastantze prozedura bat burutzen baitu helburu dramatizazio honek, ahotsen elkarrizketa itxurak harturik.

\section{2. Monologo dramatizatua}

Etiopiako zirkuluetan zehar ni lirikoaren enuntziazioa bata bestearekin loturarik ez duten jarrera liriko desberdinen bitartez mintzo da, beraz, ahots bakar bat, aurreko atalean aztertu ditugun enuntziazio alternanteen bidez adierazten dena. Gisa horretan diskurtso hautsi eta etena sortzen du, fikziozko egoera baten zantzu lausoak iradokitzen dituen ikuspenpuntuez. Drama liriko batean bezala, poemak makroegitura batean biltzen dituen diskurtso desberdinei eusten diete jarrera liriko horiek.

Etiopiako testuak enuntziatzen dituzten ahotsek T. S. Eliotek bere poemarioetan "antzesten" dituen monologo dramatikoak gogorarazten dituzte: entzuleria isil eta diskurtsoa enuntziatzen den egoerarekiko enpatiko den bati esandako diskurtso dramatikoen moduan 
sortua $^{61}$ eta The Waste Land ${ }^{1}$ izeneko poemaren bidez garatua (1922). Egitura fragmentatua du Eliot-en testuak, inolako ohartarazpenik gabe entzuten diren ahotsak, lekuak eta denborak aldatuz poeman zehar. Enuntziazio modua elegiakoa da gehienbat, baina ustegabean hari elkartzen zaizkio jatorri eta literatura ezberdinetako ekarpenak. Izanez ere, interesgarria da oroitzea Elioten poema modernistaren lehen izenburua He do the Police in Different Voices ${ }^{62}$ izan zela: "Poliziarena egiten du ahots ezberdinez". Izenburua Charles Dickens'en Our Mutual Friend [Gu bion laguna] eleberritik hartutako aipamen batetik dator. Zehazki pertsonaia batek, Betty Higden alargunak, Sloppy bere semetzakoaz hala baitio, "You mightn't think it, but Sloppy is a beautiful reader of a newspaper. He do the Police in different voices."

Azkenean erabili ez zuen titulu horrek argi agertzen du Elioten liburuaren egituraren nondik norakoa, izan ere, hainbat kritikok adierazi duten moduan, ahots ezberdinak entzuten badira ere, leku nahiz garai ezberdinetakoak, azken batean kontzientzia bakar baten adierazpen poliedrikoa besterik baita, handik eta hemendik harturiko askotariko aipamenez hornitua, hala goi mailako egileenak nola kultura popularretik ekarritakoak ${ }^{63}$.

Atxagaren liburuko ahotsaren eta enuntzioazio modu ezberdinen moldaketa polifonikoaren eta barne-kontzientzia elegiakoaren parekotasunak pentsarazten digu Etiopia eta The Waste Landen arteko transtestualitatea dagoela, Gerard Genetten terminologiari atxikiz, zehaztasunez esanik, Genettek "transformation indirecte (ou imitation : engendrement d'un nouveau texte à partir de la constitution préalable d'un modèle générique" definituriko modalitatea genuke, enutziazio liriko askotariko eta dramatikoaren imitazioa. Izan ere, ez dirudi oso desbideratua pentsatzea Bilboko Pott taldean Arestik izandako itzalak eta haietan sustraituriko Elito-en obrarekiko zaletasunak zerikusia izatea, esate baterako, bai Atxaga eta bai Sarrionandiaren liburuek makrotestu egiturari heldu izana, biek ere ibilaldia edota bidaiaren metaforari eutsiz eta, agian, Arestik berak Maldan behera mitikoan saiatu zuen makroegituraren morfologia berari eutsiz eta enuntziazio anitzaren ildo berean.

\subsection{Fragmentarismo poetikoa}

Arestian erakutsi den moduan, etekina handia ateratzen dio egileak ahots erregistro ezberdinak, pertsonaiak edo maskarak sortzeko duen ahalmen fikzionalizatzaileari, haien bitartez igortzen du mezu asaldagarriari giro oniriko baten indarra eta inkoherentzia eratxekiz. Prozedura horiek baliatzeak, ordea, enuntziazioaren ikuspegitik edonolako homogeneotasun erreferentzialen haustura eta sakabanaketa dakar, Fernando Cabo eta Maria do Cebreirok (2006) jokabide "dekonstruktiboa" izendatzen zutenaren ildoan jo baitu egileak, ahots eta enuntziatzaile anitzek esku hartzen duten testuen arteko collage moduan integratzen baitira.

61.- An example of a dramatic monologue exists in My Last Duchess by Robert Browning, when a duke speaks to an emissary of his way, "Porphyria's Lover" also by Robert Browning, "The Captain of the 1964 Top of the Form Team" by Carol Ann Duffy, and "Lady Lazarus" by Sylvia Plath.

62.- Eliot, T. S. (1971) The Waste Land: A Facsimile and Transcript of the Original Drafts Including the Annotations of Ezra Pound Edited and with an Introduction by Valerie Eliot, Harcourt Brace \& Company.

63.- Pott taldeko kideek Elioten obrari izaniko miresmenaren zantzu ugarien artean, euren aldizkariaren lehen alearen kontrazaleko iragarkia dugu, Lau cuartetto poema liburua, Gabriel Arestik euskaratuta argitaratzeko asmoa. Bestalde, taldeko kideek The Waste land bera euskaratzeko asmoari ekin zioten, askoz berandu arte burutu ez zen asmoa. 
Poetaren jokamolde horrek ezaugarri modernistak ditu, aipatu dugun Eliot-en "eredua" aintzat hartzen bada; bestalde, XX. mendearen azkenetako poesiaren era enuntziatibo anitzek genero narratiboarekin identifikatu diren hainbat eratako formulazioei eman diete bide. Izan ere, testu lirikoaren enuntziazio posmodernoak ildo narratibo horri eman dio lehentasuna, eta ni poetikoari edo zu interlokutoreari zuzenduriko formulazio apostrofikoak oso gutxitu dira.

Teoria mailan, genero lirikoaren ezaugarri propiotzat jotzen da, axioma estrukturalistaren ondare gisa, testu poetikoaren izaera bakuna, haren organikotasuna eta bere elementuen barne egituraketa edo osaera hierarkikoa. Pozuelo Yvancosek (1988:199) "Estructura y pragmática del texto lírico"64 izenburuko kapituluan laburtzen duen bezala, "diskurtsu poetikoa barne kohesio berezia duen diskurtsu literarioa da (egitura formal bereziki sendoa duena) eta irauteko asmoz osatua"65.

Planteamendu horrek oinarrian testu oro egitura bat delako printzipio estrukturalistari jarraitzen dio. Batik bat genero lirikoari begira sortutako planteamendua izan zen eta Roman Jakobsonek bere Poesia de la Gramática y gramática de la poesia (orig. 1968) estudioan argitaratutakoari estrukturalistek eta postestrukturalista semiotikoek berrespena eman zioten: hots, baliokidetasun foniko, gramatikal eta semantikoa da, hortaz, "rasgo constitutivo de la secuencia poética" edo euskaraz adirazirik, "segida poetikoaren ezaugarri eta osagarria". Poemaren teoriaren aspektu hori S. Levinek garatu zuen, arrakastaz, Estructuras lingüísticas en poesía (1974) lanean ${ }^{66}$, parekatzeen edo couplingen azterketaren bidez, eta hala erakutsi zuen poesiaren hizkerak bere-bereak dituela egitura parekatzaileak eta haien bidez testuaren egituraren funtzio bateratzailea finkatzen dela. Beren aldetik, A. J. Greimasek ere, bere Semántica estructural (1971) ${ }^{67}$ lanean isotopia kontzeptua garatu zuen testua esanahi multzo hierarkizatu bezala agertzeko. Ez dago luzatu beharrik testu literarioaren "egituratasun"ean oinarriturik, kritika estrukturalista psikologikoak edota sozialak iritxi zuen etekin aberatsaren berri emateko eta literatur testuaren egitura izaera koherentea eta kohesionatuaren axiomak izan duen ondorio sakonak iradokitzeko.

Poemaren maila guztietako elementuen (foniko, lexiko, sintaktiko eta semantiko) koherentziak, homegenotasunak eta uztardurak testu unitario, autonomo, egituratu eta irauteko sortutako baten ideiaren alde egiten zuen. Printzipio horiek bereziki dira operatiboak dira, poesia modernoa aztertzerakoan garatzen dituen hainbat paradigmatan. Gaur egun, ordea, F. Cabo eta M. do Cebreiro Rábadek ${ }^{68}$ dioten bezala, ni lirikoaren enuntziazio modua poemario berean aurreko atalean esan dugun punturaino aniztu eta desberdindu denez, gure iritziz, hor egituraketa koherentea eta paralelismo, coupling eta isotopien bidez uztartuaren printzipioa, behartu eta kordokarazita uzten dute poesia molde honen haustura zantzuek,

64.- (POZUELO YVANCOS, José María, Teoria del lenguaje literario, Cátedra, Madrid, 1988, pag. 199 y ss.).

65.- "el discurso poético, es un discurso con especial cohesión interna (estructura formal muy fuerte) y con voluntad de permanencia"

66.- LEVIN, Samuel R. Estructuras lingüísticas en poesía (Catedra, Madrid, 1974.

67.- GREIMAS, Algirdas. J. Semántica estructural, Madrid, Gredos, 1971. (original de 1966).

68.- CABO ASEGUINOLAZA y M. C. RÁBADE, "La fragmentación del discurso poético" in Manual de teoría de la literatura, Madrid, Castalia, 2000, 307-313. 
hots, fragmentarismoa deritzanak. ${ }^{69}$

Gauza jakina da fragmentarismoa edo poesia diskurtsoaren hausturaren fenomenoa, kultura garaikideari soilik datxekiona ez bada ere, "modernitate/posmodernitate" ardatzari lotzen zaiola beste ezeri baino indar handiagoz. Fragmentarismoa, bere adierazpen askotarikoekin, poesia posmodernoaren behar poetikoa da. Aurrekari moduan, Ezra Poundek bere "Papyrus" poeman egindako keinua aipatu ohi da, hots, Safo poetaren pertsonaren maskaraz mozorrotuz testu-zati fiktizio bat sortu izana. Poema labur horretan Poundek antzinateko literaturen, modernoen eta ekialdekoen topaketa bat egina zukeen lau ikuspegitatik: antzitateko ahots poetikoa birsortu, Poundek berak Saforen "maskara" hartuta, Browningek sortu zuen bakarrizketa dramatikoa erabili zuen, Eliotek bezalaxe, testua asmaketa edo aipamen imaginarioa balitz bezala planteatu zuen, eta, azkenik, poema ustezko egoera hautsi batean aurkeztu zuen, fragmentu moduan ${ }^{70}$.

Diskurtso poetikoa zatien metatze edo bildumatze gisa eratzearen ondorioz, egungo teoriak poema zentzu unitate bere horretan nahikoa eta askitzat duen ideia baino harantzago doan irakurketa eta interpretazio eredu bat proposatzen du, eta poema "zatiak" osotasun baten, hots, "liburua"ren partetzat hartzen ditu; bilduma poetikoko unitate handigoei uzten die horrek poemaren protagonismoa, zeinetan poemen arteko erlazioak protagonismo berri bat hartzen duen eta ondorioz, esanahiz abalagoa hartzen.

Beren zati-izatea edo hautsi-izatea ezaugarritzat duten poema multzoen kasuan, irakurketa kritikoa ez zaio, hortaz, poema deritzegun unitateen deskribatzeari lotuko, aitzitik, "zatitzat" hartu beharko ditugu, osotasun hautsi baten aztarnak diren collage pusketatzat, zeinarekin in absentia erlazio bat ehuten duen. Adibide eta eredu garbia T. S. Elioten Waste Landen azken atala, collage eleanitz moduan eratzen diren atalez osatua.

Beste alde batetik, poesia hizkuntzaren fragmentarismoak baditu beste ondorio pragmatiko batzuk ere, zeren, dela forma espazialaren eta hizkera lirikoaren berezko interakzioari esker, dela poesia posmodernoaren ezaugarri den fragmentarismoari esker, irakurketa aktiboa egiteko pizgarri bilakatzen da ezaugarri hori, eta loturarik gabeko hitz sailen artean esanahizko loturak egin ditzaten iradokitzen zaie irakurleei. Izan ere, alderdi ludikoak eta irudimenari ekiteko gonbitak nabarmen hartu zuten indarra Etiopia bezalako obra batean.

Fragmentarietateak idazlanaren esanahi-autonomiari eragin zion aldakuntzaz gain,

69.- Badira horretaz, besteak beste, Tua Blesak garatu dituen azterketa batzuk: Logofagias. Los trazos del silencio, Zaragoza, Tropelias, 2005

70.- BLESA, Tuak Ezra Pound-en, Personae. Los poemas breves liburuaz esanak irakur daitezke ABC CULTURAL, (11-03-2000): «Al prologar los Selected Poems (1928) de Pound, T.S. Eliot se refería al poema Homage to Sextus Propertius con estas palabras: «No se trata de una traducción, sino de una paráfrasis, o más apropiadamente (para el lector formado) de una 'persona'. Tal término no era nuevo en la obra poundiana, sino que él mismo lo había utilizado años antes situándolo como título a uno de sus libros, Personae (1909). Esta voz latina, cuyo significado es 'máscara', ha venido sirviendo para nombrar uno de los hallazgos clave de la poesía moderna, el de la creación no ya de un discurso, sino de una voz que dice tal discurso, desplazando así a la del propio autor; logro que se debe a Robert Browning, de quien Pound fue un atento lector y admirador.» 
testuaren morfologiari berari ere aldakuntza nabariak egin zizkion. Horra, besteak beste, jolas tipografikoek iradokitzen duten ildoa. Atxagaren joera ludiko eta kreatibitatearen erakusgarri moduan balio lezake lehen lerroan "Keops, Khefren eta Mikerinos" dioen poemaren bokalekin jolasten duen kriptogramak. Bistarako nabarmenago egite aldera, joko kriptogramikoan bokalak beren hitzetik bereiz agertzen dira:

Oilarrak desordutan iratzartzen gaitu

A larguntsak nigar egiten dute maiatzean

Sagarren loretatik harantzago kukuak mutu dirauelako

Rainer Maria nola biziko gara

Urkamendia jasota jadanik etorkizunaren bihotzean bertan

Eta ekia sangaren begi elektrikoa bezain krudela goizero

Urratua egun hauen sabela

A rratoiak katedraletan ere

E rreta iraganari buruzko filmik hoberenak gesalez

E rmanó, fosforozkoak gure desesperantzaren ertzak

Disko bat dedikatu behar hidake i rratiz.

\section{ATALA: IRAKURKETAREN MAILA SINBOLIKO-INTERPRETATIBOA}

Liburuaren makrotestuaren eduki sinbolikoari helduko zaio azterketaren maila honetan. Etiopiaren egitura formala eta sinbolikoaren egiturari erreparatuko diogu jarraian, ondoren, paratestu nagusien azterketa xeheari heltzeko eta azkenik, irakurketa interpretatiboa finkatzeko helburuz, liburuko bi topografia nagusiek iradokitzen duten sinbologia aztertuko da, posmodernitateari buruzko hausnarketaren markoan izan lezakeen kokatzeari buruzko argudiaketa burutuz.

\section{1 makrotestua: paradisua/desparaisua}

liburuaren egitura antolaketak duen garrantzia iradoki da liburuaren enuntziazio modu ezberdinek eta fragmentarismoak goragoko egituraketa batean hartzen duten esangura eta eskatzen duten interpretazio ildoa iradokiz. Unea da beraz, liburuaren egiturak iradokitzen duen esanahiari heltzeko eta, hortaz, testuaren interpetazio lorratzak argitzeko.

Ezaguna denez, Atxagak, akats tipografikoengatik eta bere hiztegiaren arbitrariogatik desenkusako orrialde baten ondotik, bi hitzaurre narratibotan bere etika eta estetikaren defentsa eraiki zuen. Biak dira manifestu poetikoak:

$\square$ Lehena, "Kain.Abel" izenekoa, Kain apatrida biblikoari eskainia, lehen erreboltari mitikoari eginiko aitormena da eta jarrera hartze iraultzaile edo erreboltariaren aldarrikapena.

$\square$ Bigarren hitzaurrea, "Piolet poeta lirikoari buruz zenbait apunte" izenekoa, Piolet izeneko poeta apokrifoari eskainia da. Izenburuari darraion parentesian dioena: "(Hitzaurre gisa, eta omenez)", bere asmo lirikoei guztiz entzungor agertzen den gizarteari zuzenduriko erronka eta desafioa da: "Piolet izan den poetarik inportanteenetakoa dugu, eta eskola oso 
bat sortu du mundu guztian. Eta eskola horretakoa naiz ni ere, ene humiltasunean" (Etiopia, $1983,21)^{71}$.

Poemaren enuntziazio testuingurua diren bi hitzaurreotan ikus daitekeenez, guztiz defentsiboa den ozarkeriez kutsua nabari da, ez da hortaz, desegokia azken narrazioak poetaren asesinatzearekin amaitzea. Aurrez iradokitako susmoen kunplimendua, poetaren erabateko bakardadearen eta inguru etsaiaren azken froga.

Lehen hitzaurreak orri beteko luzera du eta 1983ko bigarren edizioan ezabatu egin zen, egileak lehenengoan pairatutako lan egoera zailen testuingururako idatzia baita. Bigarrena eta hirugarrena, aldiz, jarrera ideologiko, bital eta kredo poetiko pertsonalaren manifestutzat hartzen dira. Manifestu horietan, bere "aurrekari" ideiologiko eta estetikoak izendatzen ditu, Kain biblikoa, Jainkoaren legearen aurkako erreboltaria, eta, bigarrenik, pertsonaia imaginario bat: Piolet poeta, ni poetikoaren benetako alter ego parodikoa.

Ezaguna da Pioleten bizitza imaginarioaren atzean Marcel Schwob ${ }^{72}$-en Bizitza alegiazkoak liburutik harturiko eredu baten testuartekotasuna azpimarratu dela, bereziki "Cecco Angiolieri. poète haineux" narrazioa. Deserrotzearen pairamena eta poetaren egitekoaren autonomiaren aldarrikapena azpimarra daitezke Atxagaren eta Marcel Schwob idatziriko alegiazko bizitza horien antzekotasunean: agintearekiko ukoa lehenik (aitari, maisuari, agintari militarrei...) eta "konpromisoaren" kontrol soziopolitikoari eginiko ukoa, bigarrenik.

Bi hitzaurre eta hitz-atze batean bildurik dator, azkenik, Etiopiako muina, poema eta narrazio-testu laburrez osatua.

Etiopiaren makroegituraz adostasun nabaria sumatu genuen kritikoen artean lehen argitalpenari buruzko iruzkin kritikoetatik hasita Divina Commediarekiko paralelismoak zituela eta osoki batasuna ematen zion ardatz bati atxekitzen zitzaiola ${ }^{73}$. Ezaugarri posmodernoko poemarioetan sarritan protagonismoa bilduma poetikoko unitate handiagoetara aldatu izan da, makrotestura, eta horietan poemen arteko erlazioak esanahi integratu bat hartzen du: poemaren egiturak baino esangura geheiago du haien arteko hartuemanak. Cesare Segrek $(1985)^{74}$ azaldu duenez, makrotestua autonomia partziala duten testu multzoa da, testu zabalago baten zati bilakatzen diren testuen testu-bilduma. Horretarako, poetak osotasunaren arabera homogeneagotzen ditu testuak, desoreka eta disonantziak sor ditzaketen berezitasunak kenduz, edo azken bateratze edo harmonizatze bat eginez. Beste kasu batzuetan, makrotestuan kohesio eragileak indartzen dira, dela errubriken eta emandako batasuna sendotzen duten

71.- Etiopia ko lehen edizioa paginatu gabe dago. Artikuluan zehar, 1983ko bigarren argitalpeneko orrialdea adieraziko da.

72.- Marcel Schwob (1867-1905) idazle frantsesak eragin nabarmena izan zuen Bernardo Atxaga idazle gaztearen poetikan. Vies imaginaires (1896) [Bizitza alegiazkoak, Joan Garziaren itzulpena) Etiopiaren hitzaurre honen atzean aipatu den gisa berean, Roi au masque d'or (1892), aurrerago aipatuko da Etipiaren liburuaren egituraketan ipuin liburu horretako narrazio batek izandako funtzio garrantagatik. Bestalde, Le Livre de Monelle (1894) eta La Croisade des enfants (1896) ere aipagarri dira haren gaztelaniazko itzulpena (La cruzada de los niños 1949), Jorge Luis Borges-en hitzaurreaz argitaratu zelako, lehen Atxaga haren bide erakusle nagusi izan zena.

73.- Ikus Arana, L., OtaEgi, L., (1980), “Atxagaren 'Etiopia'z zenbait apunte”, Xaguzarra 1980-1, 123-130.

74.- SEGRE, Cesare, Principios de análisis del texto literario. Barcelona, Crítica, 1985. 
beste sailkatze-sistema batzuen bidez, hasierako eta amaierako testuen balorazioaren bidez, edo parabola kalkulatu bati erantzungo dion antolamendu baten bidez. Makrotestu izaera duten testuen antolaketan, bereziki hartzen da kontuan bildutako testuen arteko koordinazioa, bai testu osoarekiko eta testu jakinen arteko erlazioen eraketa, bai sortutako segidaren ordenaren barruan. Testuaren koherentzia orokorra progresioan hartzen da kontuan, ondotik datorrenak aurrekoa asimilatzen duela. Hortaz, testu bakoitzak bere autonomia eta barne kohesioari eusten dio, beti ez bada ere, eta gero, poema autonomia eta kohesio zabalagoan, makrotestuarenean, bilduta geratzen da irakurketa esanahi ildo zabalago batean kokatuz (Segre, 1985; 47-9).

Makrotestuaren teorikoen arabera (Cesare Segre, Arcadio Casanova) ${ }^{75}$, makrotestuaren diseinua, batetik, formante dispositibo batzuen bidez eratzen da. Aipa ditzagun, besteak beste, funtzio pragmatiko-informatiboa betetzen duten adierazle paratestualak (izenburua, lema, aipuak, hitzaurreak, aurkibidea, epilogoa, oharrak, etab.) kanpo antolamendua zehazten duten testu diseinuko elementuak dituztela. Bestetik, egitura formanteak, barne forma eratzen dutenak, pertsona, gaia, figurazio, etab., ardatz edo isotopiei dagozkie eta aurrekoak bezain egituratzaile dira. Poemario klasikoetan autonomia propioa izan eta gaien aldetik antolatzen ziren sailka, eta kanpo egitura moduan ulertzen zen aurkibide egitura batean moldatzen ziren poemak. Aldiz, makrotestuak zentzu integral esanguratsuagoei lotzen eta atxikitzen zaizkie, eta adierazle formalen arabera interpretatu behar dira: hots, paratestuen azterketa zehatza eskatzen dute.

Euskal literaturaren arloan, makrotestu poetiko gisa aipa genitzake ziurtasunez Gabriek Arestiren liburuak, eta bereziki aipagarria da, bestelako hainbat antzekotasunez gain, Maldan behera poema sinbolista eliotiarra, euskal kritika akademikoak sakontasunez aztertu eta eztabaidatu duen makrotestu poetiko guziz interesgarria ${ }^{76}$. Ez da, beraz, desbideratua izango Arestiren 1959ko poemaren estruktura eta narrazio mitikoaren eiteak Atxagaren Etiopiaren ezaugarriekin alderatzen duen azterketa, bakoitzaren egitura, ezaugarriak eta transtestualiattea zehazki deskribaturik.

Atxagaren lehen poesia liburuari makrotestuen azterketarako metodologia aplikatuz gero, hainbat osagai interesgarriren funtzioaz ohartzera gatoz. Hala, kohesio eragiletzat har genitzake zentzu osoz liburu barruko izenburuak, paradisua inguratzen duten bederatzi zirkuluak zenbatuz: "Lehen zirkulua", "Bigarrena", "Hirugarrena", "Laugarrena", "Bostgarrena", "Seigarrena", "Zazpigarrena", "Zortzigarrena” eta "Bederatzigarrena eta azkena". Bederatzi zirkulu erdigune berekok osatzen duten egitura batean eratutako poema-bilduma da Etiopia; eta arestian aipatu dugunez, berehala identifikatu ziren Dante Alighieriren Divina Commediako zerua antolatuta dagoen bederatzi esferekin. Barne bilbadura eratzen duten zentzu-egiturek, bestalde, esangura konnotatiboa dakarte, hots, obra bigarren maila bateko sortze-lan gisa ezartzen dute, Danteren lan handiaren transformazio konplexu gisa har liteke, beraz, Genetten

75.- LOPEZ-CASANOVA, Arcadio, Macrotexto poético y estructuras de sentido. Análisis de modelos líricos modernos, Valencia, Tirant Lo Blanch, 2007.Arcadio López-Casanovak mikrotestu poetiko batzuen azterketari egin ekarpenak bildu ditu, Juan Ramón Jiménez, Federico García Lorca, Miguel Hernández, Vicente Aleixandre eta Celso Emilio Ferreiroren testu osoen bost azterketa xehe eskaini ditu. Makrotestuaren ereduari buruzko proposamen kritiko berritzailearen abantaila metodologikoak ezaguztera eman nahirik.

76.- Ikus besteak beste I. Sarasola, 1976; A. Arkotxa, 1993, I. Aldekoa, 1998 
terminologia erabiliz ${ }^{77}(1982)$.

Beharrezkoa da halere azpimarratzea, sarritan esan den moduan, Atxagaren poetikan transtestualitateak berezko protagonismoa duela, eta besteak beste, Etiopia liburuan konnotazio transtestualen ustiaketa bereziki emankor gertatu zela. Atxagaran idazte estiloak egia bihurtu zuen aldi hartan Genettek Palimpsestes-en esanikoa: "Lobjet de la poétique est la transtextualité ou transcendance textuelle, tout ce qui met le texte en relation, manifeste ou secrète, avec d'autres textes". Hamar urte beranduagoko Obabakoak ipuin bildumaren baitan ere M. J. Olaziregik azpimarratu zuen gisan, W. Gass eta R. Scholes-ek "metaliteratura" deitu zutenaren ekarpenak bereziki bideratzen baitu egileak irakurlearen harrera, era bateko eta besteko iruzkin metanarratiboen bidez (1997:74-75) ${ }^{78}$.

Arestian diskurtsu poetikoaren enuntziazio eredu hipotestual gisa The Waste Land, Eliot-en poema izan daitekeela iradoki dugun gisa berean, Etiopiaren makrotestuan hipotestu egituratzaile funtsezkoena, edukiaren antolamendua erabaki duen erreferentea, Danteren Divina Commedia dagoela iradoki genezake, deliberatuki gauzatutako praktika hipertestualari erantzuten baitio poema multzoak zirkulu hitzez bataiatu eta antolatu izana. Interpretazioari begira, guztiz esanguratsua den ildoa eraiki zuen modu horretan, izan ere, Danteren ibilaldiak Paradisua eta arimaren salbazioa xerkatzen duen modu berean, Atxagararen ibilaldiak Utopia bilatzen du, paradisuaren beste izena. Izan ere, egileak adierazi duen moduan, paradisuaren desioa gizakiaren baitan sakon errotuta dagoen ametsa da, gizon orok infernu hurbilari aurka egiteko, bere baitan errotua duen inbertsio amets bat, gehienetan errealitatearen klabe jakin batzuetan oinarrituta eta giza premien sinplifikazio radikala besterik ez dena.

Bereziki da emankorra Etiopiaren kasuan paradisuaren inguruko hausnarketa egituratzailea baita neurri handi batean. Makrotestu poetikoaren funtsamendu teorikotik abiatuta, López Casanovak bere liburuaren sarrera-hitzetan dioen bezala, ez dira ugari literatur estudioen arloan makrotestuari buruzko ekarpenak, eta harrigarri ere bada mugapen bibliografiko hori, zeren testu tipologia horrek garrantzi handia baitu hartua lirika modernoko obra poetiko garrantzitsuenen artean. Horregatik, enfoke metodologiko batzuetatik eta besteetatik eginiko hurbiltze analitikoan gorpuzten du, zenbait egileren inguruan.

Bernardo Atxagaren obrara antzeko hurbilketa aplikatzeko ahalegin apal eta, halabeharrez, behar baino labur honetan, lehenik, ongi ezagunak diren datu batzuk dakartzagu poemarioari buruzko bibliografian. Etiopia poema, testu-zati, aipu eta testu narratiboz osatutako liburua da, izaera liriko desberdinekoak dira, baina bildu testuen arteko koordinazioa, osotasunarekiko eta hurrenez hurren gauzatu ordenaren barnean testu jakinen arteko erlazioak sortzen dituzte.

Etiopiaren muinaren egitura diren bederatzi zirkuluak aztertzen hasi aurretik, uste dut

77.- Gérard Genette, Palimpsestes. La Littérature au second degré, éditions du Seuil, 1982. L'hypertextualité est toute relation unissant un texte B (hypertexte) à un texte antérieur A (hypotexte) sur lequel il se greffe d'une manière qui n'est pas celle du commentaire. » L'hypertexte est un texte dérivé d'un autre texte préexistant au terme d'une opération de transformation. : transformation simple (transposer l'action du texte A dans une autre époque : Ulysse de Joyce) ou transformation indirecte (ou imitation : engendrement d'un nouveau texte à partir de la constitution préalable d’un modèle générique; ex. : L'Énéide).

78.- Olaziregi, M.J. (1997) Bernardo Atxagaren irakurlea, Erein, Donostia. 
egoki dela azaltzea 1978ko lehen edizioaren ordez, 1983koa erabiliko dugula hemen aipamen guztietarako, ondoren adieraziko diren zenbait arrazoirengatik. Lehena da lehen argitalpena orrialde zenbakirik gabe gabekoa zela eta poemetan zenbait akats tipografiko badirela, bigarrenean zuzendu direnak. 1983an berrargitaratu zuen Erein argitaletxeak, lehenengo edizioko azalaren irudi beraz, baina egilearen idazlanaren izenburua gehiago nabarmenduz. Aldaketa ortotipografikoen artean aipagarri da bereziki puntuazioa. Lehen bertsioan ez zeuden zeinuak erantsi zitzaion testuari, arauzko ortografiazko eguneratuz ${ }^{79}$. Bestalde, bi poema erantsi ziren 1983ko edizioan, zehazki bederatzigarren zirkuluan: "Camamila edanez" eta "Esploradorearena". Izanez ere, autorearen esanetan, Bilbaoko aldi hartakoak ziren eta makrotestuaren azken posizioan garrantzi eta esangura berezikoak kontsidera zitezkeen.

$1983 a z$ geroztik, Atxagaren poemen edizioek Etiopiako testu jakin batzuk hautatu eta beste batzuekin batean antolatzen dituzte, baina ez dute inoiz mikrotestua osorik erreproduzitu. Hala, Obabakoak obrarengatik 1988an Espainiako Kultura Ministerioaren Nobela Sari Nazionala jaso zuenean, Madrileko Visor argitaletxeak PoemasEHibridos (1991) argitaratu zion. Liburuko poemen selekzioa zen, eta multzoka antolatu zituen poemak nolabaiteko azpigenero lirikotan sailkatuz: Poema eta kantuetan bildurik. Etiopiaz geroztik idatzitako beste testu batzuk ere erantsi ziren, "hibridoak" bide direnak, eta Henry bengoa inventarium (1987) poema sorta egituratuaz osatu zen. Poemarioaren ordenamentua eta egitura aldatzeaz gain, bada beste aldakuntza garrantzitsu bat poemetako batzuei dagokienez: tituluak ere badituzte 1987 z geroztik. Aldaketa horiez gain, esate baterako, "Berandu dabiltza" testuko estrofa batzuk kendu egin dira. Bestalde, 1996an Nueva Etiopía argitaratu zenean (LCD. El Europea, Madrid) "Canciones, conversaciones y poemas" azpititulua eman zitzaion, liburuan jasotako testu genero desberdinen azalpen moduan. Formatu txikiko liburua da (CD kaxa baten tamaina berekoa). Autoreak berak hautaturiko musika eta kantuez osatu zen CDa, abeslari eta musika talde batzuek eta besteek eginiko poemen bertsio abestuak dituztenak. 1978ko lehen poemarioko testu batzuk baizik ez dira jaso azken edizio horretan, hiru zehazki: "Hi hintzena", "Lizardi" eta "Berandu dabiltza"eta horietaz gain bigarren edizioan argitaratu zen (1983) "Esploradorearena" ere tartean agertzen da. Testuaren partean hautatu kanten letrak jaso ziren (bi hizkuntzetan, euskaraz eta gaztelaniaz). Horretaz gain, Atxagaren testu batzuk gehiago agertzen dira, abeslarien eskariz eginak eta zenbait prosa zati txikiz osatzen da alea.

Aurreko paragrafoetan zehaztu diren datu klabeen argitan egin daiteke orain Etiopia liburuaren -egitura luze eta zabal deskribatu eta interpretatu da- irakurketa globalizatzaile bat, eta uste dugu egin dezakegula ekarpenen bat interpretaziorako oinarri berri bat abiapuntu harturik. Poesia da gure ikerkagaia eta Etiopiaaren zentzu globala, hain konplexua, ezin ulertuzkotzat ere jo izan da, banguardismo dadaista, hermetismo eta zentzu jakinik gabeko desordena kaotikotzat, edo metaliteratura joko lokabetzat. Aldiz, artikulu honen asmoan, makrotestuaren irakurketa proposamen bat egin dezakegula deritzot, aipatu muin poetikoari

79.- Egilearen poetikari dagokionez aipagarri da lehen edizioan Atxagak testu guztiak ia puntuazio zeinurik gabe argitaratu zituela, eta era bateko eta besteko joko grafikoak saiatu zituela, poemaren idazkeraren forma plastikoa nabarmenaraziz, hala nola akrostikoak, etab. 1983ko edizioan, aldiz, orrialdean egin espazioaren banaketa aldatu egin zen, eta poemak puntuazio markekin agertzen ziren, eta Ouliporen eraginpean garaturiko zenbait esperimentu poetiko diluitu egin zuren. 
arreta eginez, eta paratestutik testura joanez, erreferentzia kritikoak metatzea saihestuz.

Liburuaren bederatzi zirkuluko egituraz gain, atzeman daitezke liburuko makrotestuan errubriken erabilpena eta emandako batasuna indartzen duten beste sailkapen sistema batzuk. Bestalde, prologo, epigrafe eta epilogoa, hasierako eta amaierako paratestuen funtzioa azpimarratuko dugu eta, azkenik, makrotestuaren nukleoan kokatu den parabola mitiko baten zerbitzuan dagoen antolamendu jakina: bederatzi zirkuluak eta azken erreflexioa. Nukleo horretako poema edo testu-zatiek ez dute bakoitzak bere izenbururik Etiopian; bai, ordea, sail txikietan multzokatzen dituen egituratze bat, poemak eta testu-zatiak, epigrafe eta aipuen laguntzaz, hamar multzotan paratuak.

Gogora dezagun liburuaren sarreran hitzaurrea eta prosazko bi testu ditugula:

1.- Sarrerako testua lehen edizioaren zailtasunei buruzkoa da. Akatsen deskargu eta egin ahaleginaren adierazpen, baina baita, halaber, kritikoki har lezakeen iritzi komunarekiko guztizko ardurarik eza ere.

2.- Genesiseko Kaini buruzko testu biblikoa, haren leinuari atxikitzen zaionekoa "Kainen jatorrikoa izan zen Junal: hau izan zen arrabita eta maniura jotzen dutenen aita. Gu ere bere hegalpean babesten gara letra hauk izkribatzerakoan. Eta hauxe da, hain zuzen ere,gure fede artikulua bakarra udaberri berankor honetan".

3.- Piolet poetaren, suminkorraren, kontakizuna. Poeta imaginario bereziki tematsu baten biografia apokrifoa da, Marcel Schwoben Vidas imaginariaseko Cecco Angioleriren hurbilekoa, poetak "munduarekin" duen borrokaren sinbolizazio sarkastikoa. Haren miresle eta jarraitzaile ere badela adierazten du.

4.- Amaierako azken kontakizun bat idazle porrokatuarena, bere emazteak eta haren maitaleak, "esan beharrik ere gabeko" arrazoiengatik hil zutenarena.

Poetaren posizionamendu pragmatikoa aditzera ematen duten testu metaliterario nabarmenak dira lauak, poetaren patu errebelatu eta itzuriezinaren mintzabide dira. Amorraturik, sumindurik eta bere inguruak arbuiatua, Kain apatrida bat bezala, bere kulpak ordaintzeko desertuan herratua ibiltzera behartua ikusten du bere burua, baina ahots isilezin baten deiari ari zaio erantzuten, eta "patetikoa" da bere ahalegina, farregarria gizartearen begitan.

Testu "inguratzaile" horiek Etiopiako makrotestuaren muinean eratutako materia poetiko delikatua babesteko funtzioa dute. Sarrerako testuek eta idazle erailaren epilogoak bederatzi zirkuluko egituraren paratestuak dira. Egitura horretan "bildu" eta babestu dira poema luze eta laburrak eta aipatu dditugun prosazko testuak lehen hiru zirkuluetan: zinemaaretoan emakume beltz xahar baten ondoan ikusi zientzia erreportaje baten kontakizuna, eta, beste alde batetik, Caryl Chesman presoari eginiko azken bisitaren kontakizuna. Biek sentiberatasunari buruzko hausnarketa iradokitzen dute, andre xaharraren gupida dortoken patu tristeaz, eta bestetik Chessmanen zurruntasuna bere biktimekiko enpatia izpirik gabea:

"Bera baino zaharragoa nintzen arren, hitz hauk esan zizkidan antiajuak (sic) tximeletak bailiran begietatik kenduz, emaro, neurriz gain emaro esan nahi dut: a, ene biografo ttikia, oraindik gazteegia haiz zenbait gauza konprenitzearren. Begiratu nion peto, aurpegi hura harri hutsa zen".

Poemen muinera joz, aldiz, testuak eratu diren bederatzi zirkuluekin egiten dugu topo. 
152

Dante Aliguierik Goi Erdi Aroan Zerua antolatu zueneko bederatzi esfereen erreferentzia da, arestian aipatu dugun moduan. Dantek, Beatrizen bila, egin zuen bidaiara eramaten gaitu liburuak. Intertestualitatea garbia da, eta indartu egiten dute gainera, testu batzuetan eta besteetan banatutako zeruko esferei egin aipamenek, eta bereziki, hirian egin sarrerari dagokion zazpigarren zirkuluko poema zentralean bildutakoek. Horren izenburua "Harearena" da, eta euskaraz eta gaztelaniaz argitaratu zen lehen edizioan, modu adierazgarrian.

Harea lurrik anonimoena,

Hareaz eginak desparadisoaren zutabeak,.

Eta Lurra planetaren aidea ere

Hareazkoa,

Hareazkoak sateliteak,

Urano,

Venus ere

Harearena.;

Harea egotziz bihotzek

Harea erakarriz. Harea.

Baina ez harea bakarrik.

Harearekin batera malko esentziala

Eta odol bete ontzi bat.

Eta harearen artean zuek ere, gutun

Horituak, erloju

Hautsiak,

Hiztegi liliputiarra,

Espartako eskuta herdoildua;

Ba zatozte zuek ere.

Baina arratsero galduz doa guztia,

$\mathrm{Zu}$ edo argia bezala;

Gauero ez da harea baino geratzen

Ilargi krudelaren azpian. Harea.

Harea lurrik anonimoena,

Hareaz eginak desparadisoaren* zutabeak.

La arena la tierra más anónima,

Hechas de arena las columnas del desparaíso

Y el aire del planeta Tierra

De arena,

De arena los satélites

Urano

También Venus

De la arena

Expulsando arena los corazones

Atrayendo arena. Arena

Pero no sólo arena

Junto con la arena la lágrima esencial 
Y una vasija llena de sangre
Entre la arena también vosotros, rotos
Relojes cartas
Amarillentas diccionario
Liliputiense Oxidado
Escudo de Esparta
También venís vosotros.
Pero todo se va perdiendo cada noche
Como tu ó la luz
Cada noche no queda mas que arena
Bajo la luna cruel. A rena
La arena la tierra más anónima
Hechas de arena las columnas del desparaíso.

Poema hau zutabea da, liburu osoaren erdigunea edo ardatza. Bere egiturak eta baliabide estilistikoak nahiz iruditeriak Atxagaren lehen mentorea, Gabriel Aresti poeta bilbotarra datarkigute gogora, bereziki Harri eta herri (1964) poeman. Atxagaren harea Arestiren 1963ko harriaren parekoa da. Arestik Celso Emilio Ferreiroren Longa noite de pedra obratik hartua zuen erreferentzia sendotzen du Atxagaren testuak eta omenaldi, errespetu adierazpen kutsu nabaria hartzen zaio. Blas de Otero eta Arestireki duen afektu loturazko anaiartearen aitormena, Bilbao hiriko poetekiko errekonozimendu eta atxikimendu gisa uler daiteke $e^{80}$. Ondoko poema irakurrita, esaterako, begibistako da Harearena poemarekiko parekotasuna. 1978ko edizioaz geroztik euskaraz eta gaztelaniaz argitaratu zen Atxagaren poemak argiro adierazten ditu, Arestiren eskutik, harrera egin eta beren artean hartu zuten hiriko poetekiko omena islatzen duela.

"O teito é de pedra.

De pedra son os muros

I as tebras. ()

Os corazós dos homes

Que ao lonxe espreitan,

Feitos están

Tamén

De pedra.

I eu, morrendo,

Nesta longa noite

De pedra."

"Harrizkoa da teilatua.

80.- Juan San Martinek Xesus Alonso Monteroren iritziaz lagunduta baitetsi zuen Ferreiro eta Arestiren poemagintzaren arteko kidetasuna (Egan, 1987), . Jon Kortazarren "Introducció a la darrera poesía vasca (1960-1984)" sarrera iruzkinduz, Reduccións aldizkariak euskal poesiaren antologia argitaratu zuenean (1984, zb.22). 
Harrizkoak dira hormak

Eta harrizkoa ilunpea ere.

Harrizkoa da solairua

eta lehiko hesiak ere bai.

Ateak,

kateak,

airea,

leihoak,

begiratuak,

harrizkoak dira.

Gizonen begirada,

han urrutian atezuan,

hura ere

harriz egina da.

Eta ni hiltzen ari naiz

gau luze

harrizko honetan.

Danteren paradisuaren eta Etiopiako desparaisuaren arteko korrespondentzian, ordea, nekez egin daiteke harantzago intertestualitatearen irakurketan, ez baita topatzen parekotasunik bateko eta besteko zirkuluen edukien artean. Pentsa liteke Atxagak ez zuela Danteren kontakizunaren eta Etiopiakoaren arteko parekotasun estua eraikitzeko asmorik, aitzitik, ideia egituratzailetzat hartu zuela paradisuaren edo utopiaren bila egiteko bidaiaren intertestu mitiko moduan, gero egitura horren baitan beste bilaketa, beste bidaia baten urratsak deskribatzeko, hots, paradisu baten bilaketa iraultzailea, sufrimenduaren, pobreziaren eta bidegabekerien aurkakoa izango zen utopiaren edo paradisuaren bilaketa.

Etiopiak Danteren paradisuaren mitoa baliatu zuen, beraz, ukronian modernista anglosaxoiek egin zuten moduan, Joycek Ulissesen Odiseoren bidaia mitikoa, edo Eliotek The Waste Landen Grial Santuko errege arrantzalearen mitoa erabili zuen moduan, baina ez zuen haren edukiaren elementurik ekarri bere poemara. Komentario kritikoek ${ }^{81}$ (71) zirkuluetako egitura Danteren Divina Comediako Zeruaren egiturari, erdigune bateraino jaisten diren bederatzi zirkuluko egiturari egin erreferentzia kulturaltzat dute. Ez da harrigarri hori horrela izatea, izan ere Atxagak miresten dituen autoreek ere Dante toskanarraren obra etengabe aztertu zuten: bai Marcel Schwob bai T. S. Eliot eta J. L. Borges xeheki eta sakon. Esate baterako, gauza jakina da Eliotek idatzi zuela Divina Comediaren exegesi bat 1929a arte argitaratu ez zuena, eta ondoren idatzi zuela The Waste Land (1922) liburua, eta Lau Kuartetoak toskanarraren obrarekin "elkarrizketan" idatzi zuela, editoreak hala eskatuta, obraren unibertso sinboliko eta literarioa zabaltzeko erantsi zuen aipamen eta ohar ugariri bagagozkio bederen. Pott taldea ere

81.- Testuartekotasun horren lehen iradokitzailea izan zen Lide Arana eta Lourdes Otaegi- idatziriko kritika batean, 1981an argitaratua Susa aldizkariaren lehen alean (1980) eta Xaguxarra, 1, birrargitaratua "Bernardo Atxagaren Etiopiaz zenbait apunte", Xaguxarra (Revista de Literatura], 1., Hordago, Donostia, 1983, pág., 123-132 ISBN 84-85795-08-03. 
bat dator Elioten obren aldeko interes horretan; izan ere, argitaletxea aipatu obren euskarazko itzulpenak argitaratzeko sortu zen, helburu hori askoz geroago iritsi bazuten ere.

Gehi dezagun, bestalde, Etiopia inguratzen duen lurra desertuko hareak direla, Etiopiaren testua osatzeko funtzioa duten azgazkietan ederki islatzen den moduan. Hala da, desertua eta harea erreferentzia materiala dira, sinbolikotasunean eremuari, lugorriari egin erreferentzia, Thomas S. Eliotek, poeta anglosaxoiaren beste liburu garrantzitsuko lugorria, mortua bezain elkorra, denbora sustsitzailea eta eraikitzailea errepresentatzen duena, eramaten eta ekartzen duena, jasotzen eta eraisten duena. Hala berean da denboraren iragaitea neurtzen duen harea hareazko erloxuan. Hitz batean esanda, beraz, harea dela liburuko osagai sinboliko nagusia.

\subsection{Zenbait paratestu adierazgarriren azterketa}

Lehen iradoki dugun moduan, irakurketa interpretatiboa iradokitzen duen Danteren ibilaldiaren errelatuarekin lotura egiten duen zirkulu egituraz gain, beste lau ildo interpretatibo aurki genitzake liburuan paratestuen gunean kokatuak: lehena, izenburua bera da, eta beste biak bi zirkulu esanguratsuenen (lehenengoaren eta zazpigarrenaren) epigrafeetan nabarmentzen dira, makrotestuaren artikulazio gune esanguratsu moduan. Azkenik, argazkien errepresentazioak iradokitzen duen ildoari eutsiko diogu, irakurketa sinbolikoari azken interpretazioari ekiteko.

\subsubsection{Izenburua: Etiopía}

Etiopia hitzak Utopiarekin du erlazioa, eta hala irakurri izan dute lehen unean obrara hurbildu diren kritiko gehienek. Badakigu Atxagak bere liburuan intelektual, filosofo eta politikoek herritarrentzat asmatzen dituzten proiektu idealez hitz egin nahi zuela: Paradisuaz eta Utopiaz. Proeiktu amesgarri gisako horiek esaten digute munduko pobrezia, sufrimendua eta bidegabekeria inbertitu, irauli daitezkeela hiri utopiko bat antolatuta, ongizatea eta zoriontasuna ekarriko dizkiguten gizarte bizitzako antolakundeak eratuta. Hizkera erlijiosoan paradisuak deitu direnak edo utopia deituriko hiri idealak, ideologia salbatzaileek begiztatutako paradisu mundutar idealek osatzen dute poemarioaren erreferentzia mundua izenburutik bertatik, baina, zoritxarrez, utopia idealek porrot egiten dute hutsik egin gabe, eta ordainez kontsumo gizartea da iritsi zaiguna, era guztietako aisetasunez eta eskua luzatu ahala luxuz hornituko gaituela agintzen diguna.

UTOPIAtik ETIOPIArako bi bokalen aldaketa xumeak erakusten duen hiri idealaren bisionarioen aipamena, Errepublika Platonikoan edo Tomas Mororen Utopian amestutako hiri ideal eta perfektuaren trantsizioaren isla da: litekeenik eta giza andeakuntzarik handiena. Izenburuak dakarren hitz-jokoak sarkasmoa bat biltzen du bere baitan, hirurogeita hamarretan Etiopia hitzak gosetea esan nahi baitu. Etiopia "Afrikako adarra" Somalia, Djibuti, Eritrea eta Etiopiak osatzen duten eremu geografikoan dago. Europar potentzientzat interes handiko eskualdea da den kokagunea da petrolio-ontziak eta merkantzietarako ezinbesteko igarobidea delako. Liburua idatzi zen aldi hartara itzultzen bagara, ohartuko gara 1968 eta 1973 bitartean Afrika historiako lehorterik handiena nozitu zuela eta larriki murriztu zela herriaren zati handi batean elikagaien ekoizpena, eta milaka pertsonak galdu zutela bizia. Horrez gain, 1977ko maiatzetik 1978ko martxora bitartean gerra izan zuen Etiopiak Somaliarekin, nazioartean herrialdeak hartu zuen protagonismoa zorigaitzekoa areagotuz.

Lehen sei zirkuluen amaierako zirkuluan kokatzen da "Ez naun emaro iragan" izeneko 
poema, non utopiaren gaia, eta partikularzki, utopia sozialista eta komunistena, mintzagai nagusia den eta haiekiko etsimendua adierazten:"Eta nola aipatuko Ekiaren ziutatea edo Ikaria bera" (1983: 71). Zehaztasunez, Cabeten "Ikaria" irla ${ }^{82}$, edo Campanellaren "Eguzkiaren hiria" aipatzean, utopia komunistak eta teokratikoak ditu aipagai, haien frakasoa. Ildo horretako komunitarismo modu batzuk gauzatzen zirenean, hala Cabeten kasuan, esklabutza bihurtzen ziren bultzatu eta abiarazi zituzten ameslarientzat. Poema honetan esaten da era berean Fata Morganaren ilusio optikoa ipintzen du "68ko Maiatzeko" erreboluzioaren ilusioaren parean, azken utopia askatzaileak loratu zirenekoa: "Ez daramat ezer Fata Morgana ikusi nuena baizik".

Hurrenez hurreneko bi poematan aiapatzen dira: "Ez naun emaro iragan" izenburuko poeman.

"Eta nola aipatuko Ekiaren ziutatea edo Ikaria bera,

Zaldi bulartsuenaren taupadak ur tanta baino ez

Ene bihotzerako aduana pasatzerakoan ilunetatik

A rreba e rrautsa sinistaidan, desioa dun nigan.

Suaren de rrota oroz elikatzen naun.

Besteak formolean eta ni gorrotoaren baitan,

Eta nirekin mitxeleta guztiak mitxeletak, mitxeletak.

"Ez zaitez farregarria izan" poeman, aldiz, niaren desdoblamentua den zu horri luzatzen dio aurrerantzeko jokabide duinaren ilodoa, utopiak frakasatu egiten dute, beste bat da bidea:

"ez zaitez barregarria izan

ez dezazula nigar egin adoleszente hordiaren gisa

une deslai honetan kaliza eta marmolezko mahaia

zure hegal bakarrak bihurtu direnean

eguzkirako izan behar omen zuen bidaia

zubi nekatuen azpietan amaitu delako

kontura zaitez, ez dugu deus ere galtzen

izar urrunen inguruko ideia bat

edo dibulgaziotako liburuen alanbretan

kulunkatu diren planetak ez badira

kontura zaitez, ez dugu deus ere galtzen

izar urrunen inguruko ideia bat

82.- Etienne Cabet (1788-1856), filosoa, teoriko politikari utopikoa. Icariarako bidaia, utopia komunitari baten idazlea (1842). Europa osoan izan zuen eragina. Tommaso Campanella (1568-1639) filósofo y poeta italiano, autor del tratado utópico La ciudad del sol (compuesto durante su larga estancia en la cárcel), en el que describe un Estado teocrático universal basado en principios comunitarios de igualdad. 
edo dibulgaziotako liburuen alanbretan

kulunkatu diren planetak ez badira

badakit ez dugula himnorik kantatu ahal izan

eta gela huts hori dela gure altxor guztia

Baina begira nola datozen erleak

oro argi eta argizaria eztitan transmutatuz

orain klariona bailiran ezabatuko dira

oroimen gangrenatuak

gure baso ospela

badakit ez dugula himnorik kantatu ahal izan

eta gela huts hori dela gure altxor guztia

Baina begira nola datozen erleak

oro argi eta argizaria eztitan transmutatuz

orain klariona bailiran ezabatuko dira

oroimen gangrenatuak

gure baso ospela

gurekin ere izkribatuko dira

ixiltasunaren izenak

Izenburuan Etiopiaren aipamen geografikoak, eta hirurogeita hamarretako azken urteetako Utopiaren aipamenak garrantzia dutela ondorioztatzeko, oso esanahi handikoa deritzogu Lire en v.o. Espagnol aldizkari frantsesean, "Tierras imaginadas" 83 izenburuko bere antologian ezagutarazi zuen "Geografías imaginarias" (1972) poemari. Aurkezpeneko orrialdeetan Atxagak esplikatu zuenez, Utopia kronotopoaren zentzua, 1978ko liburu honetan hain presente dagoena, bere geroagoko narrazio testuetan, eta partikularzki Obabakoak obran, helduko dien R. L. Stevenson edo W. Faulkneren geografia imaginario haiek baino lehenagoko leku bat da:

"Se trató en un principio, de continentes sumergidos,

$\mathrm{O}$ de islas encantadas, o de islas de Ninguna Parte

Como aquella, paradigmática, que se llamó Utopía,

Y tambien de lugares imposibles, como Eldorado, Liliput,

O el mismo Cielo, el de los nueve círculos o esferas.

Y eran, en los libros y en las leyendas, geografias

Abstractas, llenas de Justicia, Paz, Salud, Riqueza;

83.- Lire en v.o. Espagnol, en su antología titulada "Tierras imaginarias"de enero de 1992, 7. Incluye dos textos de Bernardo Atxaga, de Gabriel García Marquez, Juan Benet, Juan Carlos Onetti, Cristina Fernandez Cubas y Jorge Luis Borges. 
Llenas, en fin, de todo lo que en este mundo,

En este valle de lágrimas, en esta Edad de Hierro,

La Humanidad en general y los escritores en particular,

Echaron en falta, desde los tiempos del primer poeta."

Poema honetan aipaturiko utopiek huts egin dute; beraz, zer egiteko du poetak jagoitik? Utopiak hilak dira, eta kristalezko jauregiak hautsi dira, ahalegin guztiek alferreko dirudite, nora egin ihes? Harearena da erantzuna, ondoko poema: hareazko errealitate gogorra, denboraren joate itzuriezina eta sufrimenduaren nahiz heriotzaren betiereko presentzia barnean hartzeko unea da. Hala dator, Etiopian liburuko zortzigarren zirkuluan erreboluzio patetikoa, "Berandu dabiltza" bezalako poemetan trazuak komikien marren estilora jotzen du edo Holiwoodeko zinemaren mitoen bitarteko errepresentaziora: emakume fatalen atributuak, Humphery Bogart, Bonnie and Clyde, King Kong...Hitz batean, utopiaren ezintasunaren ondoriozko desengainuaren kronika baten adierazpidea nagusitzen da zortzigarren zirkuluan, bederatzigarrenean, aldiz, jarrera hartze post-utopiko eta erresistentea, hiriaren konkista iradokitzen duena.

\subsubsection{Bigarren paratestua: Schwob eta Ophelion.}

Etiopia hitza, izenburuan aipatzeaz gain, liburu barnetik egituratzen duten paratestuetako bitan ere aipatzen da. Gogora dezagun sarrera gisa idatziriko prosazko lehen hiru testuen ondotik bederatzi zirkulutan egituratutako poesien gunea zabaltzen dela. Ondoren makrotestuaren irakurketa eta ulerpenerako funtsezkoa den bigarren paratestua agertzen da. Muinaren egitura determinatzen duen eta esanahia ematen dion zantzua eskaintzen digun aipu laburra:

"ene anaiak eta biok zeharkatuak genituen jadanik Etiopia inguratzen duten harea ezberdinezko bederatzi zirkuluak." ( Marcel Schwob )

Aipamena Etiopiaren lehen bi edizioetan agertzen da, autorea soilik aipatzen da, zein testutatik datorren adierazi gabe. Horregatik iraun du luzaroan bakardade kriptikoan, argitu gabea eta kontestualizatu gabea, literatura fantastiko idazle frantses asaldagarriari soilik atxikia, Pioleten kontakizunean haren Cecco Angioleriren narrazioaren antzekoa egiten zuela. Oso gauza adierazgarria da aipamen hori La Masque d'or ipuin liburuko "Las embalsamadoras" kontakizunetik datorrela argitzea, izan ere ipuinean bi anaia protagonistak Etiopiara bidean desertuan barrena ibilbide luzean egin dituzten atzera-aurrerak kontatzen baitira, halako batean hiri misteriotsu batera iristen diren arte. Ibilaldi mitikoa da, norabide eta eragile ezagunik gabekoa. Hiri bitxia eta kezkagarria aurkitzen dute, non harrera ona egiten zaien: maitasuna eta herioa topatuko dituzte, Eros eta Thanatos bata besteari estu lotuta. Gauza jakina da Marcel Sshwoben literaturan giro fantastiko-beldurgarriak direla, txundigarria 
nardagarriarekin elkartzen dira ametsetan bezala, baina beti ezaugarri errealista garbiko prosaz emana da, horrek sortzen baitu haien inpresioa iraunkorra.

Schwob-en kontakizuneko baltsamaitzaileen hiri fantasmal hori laster identifikatzen da Atxagak euskaldunentzat bereganatu nahi zukeen Bilbao hiri mamuarekin. Rainer Maria Rilkerentzat Los apuntes de Malte (1904) obrako Parisaren tankera hartzen du Bilbok eta bi poeten begiradak anaitu egiten dira: bizirik dirauten hilenganako gupida, ilunbetan, bizi beharrean diren ume eta emakume tristeenganako errukia konpartizten dute. Ez da harritzekoa, aurrerago ikusiko dugunez, Rilke bihurtzea bere galderak egingo dizkion mentorea, infernu dantear hori itzuriezinezko errealitatearen aurrean kokatzen denean, zazpigarren zirkuluan laguntzen dion Virgilio moduko bat: "Nola biziko gara, Rainer Maria?" (1983: 78).

Hirira eramango duen desertuaren sarreran egin aipameneko egoerak Etiopiara doazen bi esploradore anaien kontakizunaren aurrean jartzen gaitu, lehenengoz adieraziz Atxagaren hainbat narraziotan berrituko den anaia biren edo bi lagunen ibilbide paraleloen planteamendua. Horra, beraz, Jorge Luis Borgesen arabera, literatura fantastikoaren gai berezkoenetako bat: dobleen gaia, errealitate berari bi bidetik heltzeko parada eskaintzen duen egitura narratiboa ${ }^{85}$. Schwob-en bi anaiak iritsiko dira hirira eta gertakari sinestezinak jasaten dituzte, anaia hil egiten da egoera estrainioan, eta protagonista bila dabilkio, estuasun handiz. Horrela, zirkulu batzuetako eta besteetako testu-elementuak ibilbide horretan aurrerabidearen hurrenez hurreneko faseetan kokatzen dira. Poemarioko giroa Schwoben mundu mitikoaz kutsatzen da, errealismoaren eta amesgaiztoaren artean. Hiriaren elementu batzuek eta besteek dimentsio fantasmagorikoak, kezkagarriak, ziurtasun gabekoak,... hartzen dituzte.

Danteren obraren egiturarekiko transtestualitatea guztiz ezaguna den bezala, Etiopiaren ildo interpretatzaile berria ekar liezaioke Macel Schowben ipuin honen paratestuaren

85.- Doble edo bikien gaiaz, ikus Mari Jose Olaziregiren Bernardo Atxagaren irakurlea (1997, pp 104-110). Ildo berean aipa liteke Soinujolearen semea (2003) eleberriko bi protagonisten arteko anaitasun harremanaz Atxaga web orrian dobleak direla eta "Le main du signe" (Dominique Aussenac-en elkarrizketa.Abril 2007): "Uno de los elementos básicos de la novela es la cuestión del doble, y de ahí surge la dualidad de las versiones. David y Joseba son amigos, o más que amigos, son hermanos. En la primera redacción lo eran de verdad, y yo pensaba en ellos como en Castor y Polux. Esto viene explicado en la propia novela, cuando se habla de las incisiones hechas en lo corteza del árbol: David ha escrito sus memorias, ha dejado esa marca, esa incisión en el árbol; detrás viene Joseba que profundiza en esas marcas. Pero el tiempo borra las diferencias entre las incisiones nuevas y las viejas, y sólo queda una única inscripción. La novela está llena de dobles. Incluso los lugares son dobles. El pequeño valle de Iruain es un paraíso para David, cuando aún es adolescente. En su madurez, acabará el el rancho de Stoneham, en Three Rivers, California. Punto por punto, Stoneham es el doble de Iruain."() Vuelvo al tema del doble. EL tío "americano" de David es el doble de su padre. Es el hombre que él hubiese querido como padre. Por eso lo vemos en los dos únicos lugares que David se siente feliz: el pequeño valle de Iruain y el rancho californiano de Stoneham. Pero el rancho es un lugar más importante que el valle, porque es el lugar final, y ese lugar está a 7000 kilómetros de donde nació. El tema de fondo es el paraíso. Mientras escribía la novela escribí varios poemas con ese tema. Uno de ellos se titula "La vida según Adán", y trata de saber lo que le ocurrió a Adán la primera vez que enfermó después de salir del paraíso." 
esanahiaren azalpenak. ${ }^{86}$ Poemarioaren egituran bidaia mitikoaren oinarrizko mitemen aktualizazioan datza: deserrirako bidaia da, Marcel Schwob-en narrazioan kontatzen denaren paraleloa. Desertua gizatasunaren ukaziozko atmosferaz kutsatzen da, afekturik eza da bideko konstantea, baina hara irixtean maitasunarekin batean heriotzari egin behar zaio aurre, bizitza psikikoaren oinarrizko pultsio freudiaren adierazpen mitikoa da: bizitzaren pultsioa eta heriotzarena.Atxagak berak Leopoldo M. Paneroz mintzatzerakoan aipaturiko pultsio tanatikoa eta denboraren eragin deuseztailea oroz gainetik nagusitzen direla:

"Ene bihotzerako aduana pasatzerakoan ilunpean

Arreba errautsa sinistaidan, desioa dun nigan.

Suaren derrota oroz elikatzen naun.

Besteak formolean eta ni gorrotoaren baitan

Eta nirekin mitxeleta guztiak mitxeletak, mitxeletak. (Etiopia, 1983, 72)

Maitasun eta heriotzaren pultsioen lehiak modu mitikoan adierazia Baltsamatzaileen ipuinaren giroaz kutsatzen da, eta lokamutsen ezinen eta oihuen artean dabil gatazkan. Atxagaren poemak agian anaia biografikoak eta biek Bilbora joandakoan bizitako giroaz elikatzen da neurri batean, ez baita ahantzi behar "Beatriz Eibarrera doa" (2008) izeneko narrazioan adierazi zuen moduan, Jose Irazuren anaia poliziak atxilotu eta gartzeleratu zutela ekintza armatuetan parte hartzearen akusaziopean frankismoaren azken urteetan. Amaren heriotzaren gaiaz diharduen narrazio horretan ikusten denez, anaiaren atxiloketa eta gartzelaldia trauma sakona izan zenez familia osoarentzat, 1977ko amnistiaren ondorioz askatu zuten arte.

\title{
3.2.3. Hirugarren paratestua: Etiopia lehenengoz dibisatzean.
}

Zazpigarren zirkuluaren sarrerako hirugarren paratestu honek iragartzen du garrantzi handiko unea dela: bi anaien ibilaldian aldakuntza nagusia gertatuko den muga.

\author{
Egunak pasa dira \\ kanpamendu erratu bat gara \\ Egun argitsuagoak gure aurrean \\ Behar bada \\ Argi krudel baten pean nengoen \\ Gauzen begirada kupidagabearen pean
}

86.- Atxagak sustatu zuen Schwob-en liburuaren itzulpena. Pamielak argitarazi zuen 1987an, Pedro Diez de Ulzurrun-en egina: "Dudarik batere ez dut ezen Libian, Etiopiako azken eremuetan, non eta arras gizon zahar eta jakitunak bizi baitira, badirela aztikeriak Tesaliako azti-emaztekienak baino oraino misteriosoagoak. Egiaz izigarria da pentsatzea emaztekien enkantamenduek hilargia ispilu baten barruan herts dezaketela, edo hilbete garaian zilarrezko ontzi batetan sar urez blai egindako izarrekin batean, edo zartagina batetan preji itsas-medusa hori bat bailitzen tesaliako gaua beltza deno eta larrua aldatzen duten gizonkiek trunpatzeko libertatea duten bitartean; lotsagarria da hau guzia, baina beldur gutiago izanen nuke nik gauza horiei ezenez eta berriz ere aurkentzeari Libiako andere baltsamatzaileekin odol koloreko basamortuan. Iganak genituen anaia Ophelion eta biok Etiopia inguratzen duten harea desberdinetako bederatzi zirkuluak." 


\section{(pastiche: poema Pigmeo bat eta Genet)}

Aski maiz baliatzen den kontzeptu aristotelianoz esan dezagun "errekonozimendu" edo anagnorisis bat gertatzen dela, Etiopiako ateak begiztatzean eragingo duen jarrera aldaketa bat. Desertuan zehar egin ibilaldi akigarrian izandako galera eta sufrikarioa arindu egiten zaie esploradoreei Etiopia begiztatzean. Izan ere, zazpigarren zirkulutik bederatzigarrenera, Etiopia "beste Bilbaoren" poema da. Beste hiriaren esperientzia humanoa eta literarioa Arestiren hiriarekin topatzen da, literaturakideen, maitasunaren eta lagunen hirian. Idazle gisa Bilbon jaio baitzen Atxaga eta bere literatur ibilbidean izan duen eragin positiboari omen egite garbia da azken hiru zirkuluek osatzen duten multzoa. Eta kideen aurkiundearen ondotik (Aresti, Ferreiro, Otero, Rilke), hurrengo zirkuluan erreboluzio kulturalaren aipamena helduko da, ironikoa bai, baina erresistentea. Bederatzigarrenean euskal poetei, Etxahuni, besteak beste, desertua utzi eta hiria berenganatzera luzatzen dion deia helduko da. Azken zirkulu horretan ipini da lehen aldiz Bilbaoren izena, "the beautiful morning of Bilbao" $(1983,96)$ eta esploradorearen bidaiaren emaitza gozatsua bilakatuko da orain, eta begiak edertasunez gainezkatzen diren kolore argitsuz betetzen zaio, lehengo erdoila, euria, esnezko ibaiak, neonak eta eguzki elektrikoak ordezkatuz:

Ikus lezazke apika kristalezko irla batzuk, urre edo zilarrezko ziutate bat goizaldean;

(ikus lezazke) suge erraldoiak(,)eta tigreak (eta) ikus lezazke

bale urdinak ozeano epel batean murgiltzen;

ikus lezazke bi emakume soineko laranjatsuaz laranjatsuz

eguzkiak sututako horma baten ondoan eserita;

Ikus lezazke egun berreskura-ezin guzti horiek

txori imajinarioen multzokada saldoak lez pausatzen"

Ondorio labur gisa, paratestuen irakurketak makrotestuaren zentzuaren norabidea erakusten digu: hasi Etiopia eta Utopia hitzen jokoarekin, desertu mitikoetan zeharreko esploradoreen bidaiaren Schwob kontakizuna, eta desparadisua zeharkatuz, Arestiren hiria, literaturaren eta kupidaren esparrura iritxiko dira. Horrela lotzen ditu Atxagak Etiopiaren makrotestua egituratzen duten errelatu mitikoak. Gure ustetan, Etiopiaren hiru aipamenek Bilbao hiria seinalatzen dute, helburu eta xede, eta hiriaren jabekuntzarekin dute zerikusia, une hartan Atxaga desiratzeko modukotzat hartzen zuen erreboluzio bakarra. Euskaldun apalenek, "Ezinaren arreba" eta "Ezaren alaba" zirenek beren hiriburu desiratua konkistatzea hartzen da utopia berritzat:

"Utzi iraganaren abenidak

Ez haugu behar gorpuak zitroi urez ihurtzitzeko

Baizik eta desertuko ihizik eragitearren

Ziutaterantz" (Etiopia, 1983, 95)

Bilbaoko desparadisuan, azkenik, aurkitzen du esploradore-poetak bere ahotsa: Hainbat gauza ikus litzazke, "Esploradorena" izeneko poemaren anaforak dioskunez, eta esan ere hainbat gauza esan ditzake edo argudia ditzake "Kamamila edanez" poeman dioen bezala, edota "berresan" ere egin ditzake zenbait hitz maiztu eta etengabe errepikatuak badaude ere, 
zeren, "gauza guztiak esanak zeuden jadanik agian", mende honen hasierarako. Klitxeak errepikatu arren, idazleak badu zio bat, estimulu bat hitz egiteko kemena ematen diona: bere utopia hautatu du, hiriaren jabe egitea Ezaren eta Ezinaren kastakoontzat.

\subsubsection{Etiopiaren lehen edizioko argazkiak}

Testuaren eta paratestuaren behaketan nabarmentzen diren zeinu eta elementuek hastapenetik beretik bihurtzen dituzte bereziki esanguratsu liburuaren azaleko hitzak: Etiopia toki geografikoaren izenarekin lotua egotea eta liburuaren nukleoan, zirkulu bakoitza iragartzen duten izenburuen ondoan bederatzi argazki ikusteak "espazio" mitiko horren berezko esangura azpimarratzen du.

Desertuko eszenak dira argazkietan eta orri beteko irudiak. Paratestu modura, argazki horiek nagusitasuna hartzen dute, irakurlearen testuarekiko hartu emanean, tematika iradokitzen dute azalean eta barruan. Testuak irakurriz gero jakingo dugu zein basamortu den poetaren erreferentea, baina argazkiek berek ildo narratibo bat marraztu dute, "istorio" bat xedatzen dute. Fotografiek desertuaren gune ezberdinen irudiak erakusten dituzte, hastapeneko lur eremu soil eta hutsean ondar aleak nabari dira, formagabe, duna legunetan moldatuak. Gerora berriz, figurak osatuz doazelarik, zirkuluen edukien araberako adiera hartuko dute; hala, bigarrenean ur marka batek zehazkatu balu bezala ageri da hareatza, hirugarrenean, belar txikiak hazten diren gunea erakusten dute, laugarrenean areak forma konkortsuak osatzen ditu, eraldatua ageri da uraren era haizearen eraginez. Bostgarrenean, mugimenduan diruditen forma iheskorrak errepresentatzen ditu, seigarrenak forma eraiki baten arrastoa, ihaurriak irudikatzen ditu, ondarrean tinkaturiko arbazta batzuen formazioak agerian utziz. Zazpigarren fotografian, hondar harrotuen formazio harritsuek horma bat irudikatzen du, antzinateko hiri baten murrua datekena, zortzigarrenak, aldiz, lurretik gorantz eragindako artesia irudikatzen du. Azkenik, bederatzigarrenak, gain bat erakusten du, zeru zati zabala ikusten uzten duen irudi bakarra liburu osoan, desertua nolabait gainditua erakusten duena altura batetik. Irudien ildoari lotzen zaio poemaren muinaren egitura ere. Zirkuluetako argazkiek atzerriratzea dute abiapuntu, desertuko aldi krudel eta gatazkatsua irudikatzen dute, aldakor eta beti elkor dirauen pasarteetatik, eraikitze eta erortze bat iradokitzen dute, eta azkenik, gainditze bat, non zerua ageri den eta desertuaren azalak naretasuna transmititzen duen.

Paratestuen azterketa osatuko luke maila semantikoaren ildoan eginiko ibilaldi honek. Egitura tematikoarekiko lotura eta paratestuen artekoa bat datoz: "Harearena" poemaren zentraltasuna azpimarratu dugu eta irudiek ere istorio hori kontatzen dute: hondar-aleen etengabeko aldakuntza sumagaitza eta gizakiaren ezina, Etiopia begiztatzean aldatzen da. Izan ere, zazpigarren zirkulutik bederatzigarrenera, Etiopia "beste Bilbaoren" poema gisa ilustratu da argazkiez horma eta eraikinak igartzen ditu begiak, desertua gainetik begiratzera iritsi arte. Hiriaren esperientzia humanoa eta literarioa Arestiren hiriarekin topatzean helduko da. Egileak irakurleari eskainitako klabe literarioek mezu inplizito bat iradokitzen dute, hipertestualitatearen arloan adierazia genuen irakurketarekin bat egin duena. Horretaz gain, ezin uka poema bakoitzaren egituratzean bestelako transtestualitate konplexua aurki genezakeela, bereziki trastestualitate genettiarrak sailkatzen dituen aipamen eta zehar aipamenen ildotik hasi eta testuartekotasun mota ezberdinak baliatuz, hala nola, pastitxeak, eta aipamen metatestualak, esaterako. Ezineko litzateke hemen horien berri zehatza ematea, hain baita aberatsa atal hau, edonola ere liburuaren metaforizazio aberatsari buruzko ikerketa zehatzak garatu dituzte, besteak beste Aizpea Azkorbebeitiak (1996, 1997, 1999), Iñaki 
Aldekoak (1991, 1993a,1999b, 2009) eta Jon Kortazarrek (1994, 1997, 1998c, 2001e, 2005) eta Mari Jose Olaziregik (2007, 2009).

Paradisuarekin, utopiarekin edo "ziutate ideala"ren planoarekin zuzenki lotzen den metafora batez osa liteke atal hauxe, utopien galeraz diharduen "Orduan arratsero" poemaren pasarte

\author{
"eta herrestan doaz halaber, \\ ziutate ideialen planoak, \\ zintak teori iraultzaileak, \\ izerdiak horrenbeste min mota \\ Ofeliaren ile beilegi ahula"
}

Atxagak iradokitzen dituen pertsonaia literarioen edo historiako pertsonaia edota arte erreferentzia batzuk izendatze hutsez lortzen du oihartzun sakona, irudiez eta emozioez betetzen duena poemaren txoko ilun hau, etsimenduz beta. Zer ikustekorik du utopiaren frakasoak, teoria iraultzaileen gainbeherak, giza-ahaleginen porrotak Ofeliarekin, Hamleten andregai zoritxarrekoarekin? Rosetti prerrafaelistak margoturiko Ofelia uretan etzanaren irudia dakar, argiz betea, misterio eta kupidaz betea. Ofeliaren irudi osoa dakarkigu gogora haren izena aipatu hutsez eta haren suizidioak tindatzen du melankolia bereziaz, fluor berdearen argitasunez margotuz poemaren pasarte honen iluntasuna. Ofeliaren gorputza iradokitzen da ilearen aipamen metonimiko horren bidez eta ibaiaren indarrak beste guztiarekin batera eramana ageri du uretan, era bateko eta besteko ilusio galduen artean, maitasunezko nahigabe gaindiezinaren sinbolo doakabe gisa.

\title{
3.3. Desertua eta hiriaren topografiak
}

Etiopian topografia literarioak gailentzen zaizkie historikoei, eta guztien artean gailentzen dira desertua eta hiria. Etiopiako desertu hain literarioa (Rimbaudek errekorritu omen zuena), Marcel Schwob eta Rainer M. Rilkerena ere bada, eta Danterena, bere Infernoren erdian suzko bolak erortzen diren desertua baitago kokatua. Desertuaren ondoan, geografia utopikoak, hala nola, Gulliveren Bidaietako Liliput delikatua, eta Esparta, gerraren eta diktaduraren eremu latza aipatzen dira, azkenik hiriaren irudi berritu bata gertuko den arte.

Makrotestuaren nuklekoko poemetan nabarmendu dugun artikulazio gunearen alde batean eta bestean topografiak ezberdinak dira: lehenengoan desertu mitikoa, suntsitzailea da, etsigarria, labirintikoa. Bigarrenean aldiz, zazpigarren zirkuluan, "Etiopia lehenengoz dibisatzean", poemarioaren ildo tanatikoa aldatzen den gunean kokatzen dira paisaia berrituko duten irudiak, paratestuan iradokitzen denez, "Egun argitsuagoen" ikusmirak eskainiriko bisioak. Hor dira konformazio erraldoiak aipatzen, aski ordenatuak eta koherenteak elkarren artean: eguzki sistemako planetak, Ejiptoko piramideak eta ilargi jainkosarekin identifikaturiko Nefertiti erregina, hor da itsasoa, ibaiak eta urmaielak, guziak ere hareaz eginak, desparadisuaren materia beretik eginak: denboraz, alegia. Atzera geratu dira, seigarren atalean, utopien galeraz diharduen poema tanatikoak, paratestuak berak "Alferrik" batean bildurik utzen dituenak. Han geratu da "Ez naun emaro iragan", desertuaren paisaia mitiko amorratuaren azken adierazlea, "Lope de Agirre" bezalako pertsonaiak metonimikoki errepresentatuak: Espainiako erregearen kodizia mugarik gabea salatu zuenaren ahalegin frakasatua, Kain apatrida bera 
bezain oldarkoiaren errebelamenduaren sinbolo.

Horiez gain, ez dira gutxi liburuan topografia literarioei eginiko erreferentziak ere. Iraganeko euskal poeta handiei egin erreferentzia zehatzak: Lizardi eta haren baratza, Lauaxeta eta pantera, Mirande eta eskandalua, Etxahun eta desertuko ihiziak... Lehen biak, olerkari abertzaleak, poetari noragabetuak agertzen dira, beren garaiko literatur estetika eta joeren inguruan interesatzen ez (Rimbaud) eta mamuak jazartzen dihardutenak, ideal abertzaleek itsututa. Mirande ere agertzen da, komun publikoetako pornografiaren eskandaluaz erlazionaturik, Guztien artean, poeta erromesari, Etxahun erresuminduari deitzen dio poetak, erleak, argi eta eztia hartuta hirira etor dadin eta elkartu dakien bere mina literatura bihurtuz dihardutenei. Jean Casenave irakasleak $(2002)^{87}$ esan bezala, Etxahun poetaren pertzepzio literarioaren bilakaeraren urrats bat izan izan da Etiopia:

"Au cours des années 70 et 80, ayant définitivement perdu toute contingence humaine, il accède au cercle très restreint des écrivains basques transformés en mythe littéraire sous la plume de B. Atxaga ou de J. Sarrionaindia."

Casenaveren estudioan are da interesgarriagoa Arthur Rimbaud, liburuan ororen gain dabilen erreferente literarioa, apatrida modernoen aitagoia, poeta frantsesaren literatur mito bihurtzearekin egiten dituen parekotasunengatik.

Nolanahi ere, Lizardiren aurrez aurre baino ez da aipatzen Rimbaud "Lizardi, Rimbaud etorri duk hitzaz galdezka" poema ezagunean, harengandik behar genuena eta eman zuena aurkajarriz:

Lizardi, Rimbaud etorri duk hitaz galdezka, eta gu ere hire zain geundela

esan zioagu,

ez hintzela aspaldi azaldu

etxetik;

eta belatzean eseri gaituk denok

erlojuak janez,

baina mezularia bidali diagu/ Alosko dorrera/

eskailera luzeetan*

beleak uxatzen

ote hintzen ikus zezan.

gero kanpaiak entzun dizkiagu,

zakurrak zaunkaka;.

orduan sortu haiz bidetik,

Balantzaka,

eta hirekin aurrez aurre (jarri garenean

zerraldo erori haiz gure oinetan,

87.- Casenave, Jean, "Etxahun-Barkoxe (1786 -1862). Du poète populaire au mythe littéraire"Lapurdum, 2002 :VII) 
eta gorpu gogor hintzen

udazkenaren tronuan;

hertsi dizkiagu begiak,

adiorik ez,

eta goizaldean,

muxika hezur batean sarturik,

o petit poete

pirotekniarik gabe lurperatu haugu

baratzean.

Desentuko atalarekin batean, topografia literarioetan nagusia Bilbaoko hirian, Bilbaoren erraietan kokazten da, Aresti, Blas de Otero eta Atxagari esker literatur eszenategi bihurturiko hiriburua. Arestirentzat hiria gatazka da, errealitate gaitza eta basoaren nostalgia eragiten dion porlanezko mundu gogorra. Atxagaren Etiopiak, ordea, buruan hartua du hiri horren eraldaketa. Zein zentzutan? Divina Commediako Virgilioren funtzioa Etiopian beteko duen Rilkek haren Duinoko Elegiak komentatzean esplikatu zuen zentzuan:

"Estas poesías conducen a la demostración de que esta vida, así dependiendo de lo inseguro, es imposible. En las elegías la vida se hace otra vez posible. Es la afirmación de la vida y de la muerte... No hay ni un aquende ni un allende, sino la gran unidad [... ] La naturaleza, las cosas de nuestro trato cotidiano y de nuestro uso son, por cierto, provisionales y caducas, pero son, mientras estamos aquí en la tierra, nuestra propiedad y nuestra amistad. Ellas son consabidoras de nuestra alegría y de nuestra miseria y ya fueron las confidentes de nuestros antepasados... Las cosas tienen que ser comprendidas y transformadas por nosotros. ¿Transformarlas? Si, porque nuestra tarea es ésta: impregnarnos de esta tierra provisional y caduca tan profundamente, tan dolientemente, tan apasionadamente, que su esencia resurja otra vez en nosotros, invisible. Somos las abejas de lo invisible... El ángel de las elegías es aquella criatura en la cual ya aparece consumada esa tarea que nosotros venimos realizando de transformar lo visible en invisible...(). Nosotros somos... los transformadores de la tierra; toda nuestra existencia, (incluso) los vuelos y caídas de nuestros amores, todo nos capacita para esta tarea..." (16, p. 374 ss. $)^{88}$.

Aztertu dugun liburuaren esanahiaren egiturek proiekzio mitiko batera jotzen dute, Etiopiara bidean aurrera egin eta hirian sartzeko esploradoreak barneratzen diren desertuaren geografian zehar eginiko bidaiaren proiekzio mitikorantz. Eraikuntza mitiko horrek unibertso sinboliko konplexua eratzen du, non pertsonaia poematikoak (esploradoreak) bere burua aurkitze eta eraldatze prozesu bat bizitzen duen eta bere begirada hondamenetik bultzada sortzailera aldatzen den. Nihilismoa indar sortzailearen bidez gainditzeko ahalegin hori proiektu artistiko batean gauzatuko da, eta bat egingo du du hitzen bidez errealitate berri bat

88.- Rilkeren testuaren gaztelaniazko itzulpena Melancholia aldizkariaren 2006ko alean argitaratu moduan jaso da aipamen honetan: http://anatomyof.blogspot.com.es/2006 1201 archive.html [azken kontsulta 2013-10-08] 
166

eraikitzeko poeten lan eraldatzailearekin.

\author{
Baina begira nola datozen erleak \\ oro argi eta argizaria eztitan transmutatuz \\ orain klariona bailiran ezabatuko dira \\ oroimen gangrenatuak \\ gure baso ospela \\ gurekin ere izkribatuko dira \\ ixiltasunaren izenak.
}

\title{
3.4. Azken hitzak etiopiaren irakurketa postmodernoaz
}

Atxagaren liburuaz idatz idiren lan kritikoek poetika posmodernoaren ezaugarri izango direnen zantzuak aurkitu dituzte idazlan honetan: niaren zatikatzea eta multiplikatzea, genero nahasketa, transtestualitate eta metaliteraturaren omnipresentzia... Baina, oro har, poetika modernoaren ezaugarriak ere baditu, krisi nihilista sakona iragartzen duten elementuekin batera, eta errelatu handien krisia adieraziz.

Halere, gure irakurketaren arabera, Atxagaren nihilismo beltzari irtenbide sortzailea eman dio Etiopian, eta horren alde ekiteko jarrera erakusten du, azken bi zirkuluetan, kreatibitatearen aldeko apustua eginez eta hausnarketa metaliterarioari espazio zabala irekiz. Izan ere, idazleak eginiko desertuko trabesia horrek bere baitan baitu ahots propiaren bilaketa, ahots originalaren bila eginiko bilaketa mingarria. Hamar urte beranduagoko Obabakoak liburuan bezalaxe, Etiopian protagonistak argitasun bila dihardu errealitatearen izaerari buruzko zalantzan, azken hitz esentziala bilatuz, eta irudimenaren mugak, bildurraren erasoak eta zentzuna galtzeko kezka fantastikoek asaldatzen dutelarik. Paraleloki ordea hausnarketa metaliterarioek ere bestelako trabesia adierazten dute, erregistro poetiko bat sentimentalkeriatik ihes, klitxeetatik ihes, azken pasarteetan anagnorisia edo errekonozimendu momentua helduko den arte, "Exploradorearena" bezalako testuetan.

Postmodernitatea korronte, pentsamendu ildo edo agian aro soziokultural oso bat ote den zehazteke dago. Batetik, arlo soziohistorikoan kapitalismo berantiarrean erakusten dituen ezaugarriez definitzen da, praktika sozial ezaxolazkoak eta azalkeria agertzen dituena bere egitura ekonomiko eta mediatikoen bidez. Bereziki Jean Baudrillardek (La precession des simulacres, 1977) edo Frederic Jamesonek (The cultural logic of late Capitalism, 1991) iragarritako simulakroaren eta errealitatearen erauzketarekin identifikatzen da, gaur egun, eta ezaxola etikoa, materialismoa eta nihilismoa dira haren ezaugarriak.

Frederic Jamesonek (1985:170), adierazi zuen moduan, modernitateaten estetika organikoki lotua dago nortasun pribatu eta bakarbaten kontzepzioari, nortasun eta indibidualtasun bakar horretan mamituko baita mundu-ikuskera propioaeta estilo konfundiezin bat. (1985:170). Subjektu indibidualista hori ezinezkotzat jotzen da posmodernitatearen aroan, eta originaltasun erromantikoa ezinezkoa denez, transtestualitatearen era bateko eta besteko transformazio literarioak nagusitzen dira. Jamesonen iritziz, pastiche-a gailentzen da, izan ere egungo mundua, bere buruaren irudi den mundua bihurtu da, "hiperrealitate" bat. Iragana irudi multzo, simulakro bilakatu da. Horregatik, pastiche-aren zabalkundeak iraganaren interpretazioan simulakro bilakatzea dakar, inoiz originala izan ez den zerbaiten kopia bat eraikitzea.

Postmodernismoaren mundu-ikuskera monolitiko hori kuestionatzen da, gaur 
egun, gehiegizko determinismo soziologikoa ez ote duten aplikatzen iradokiz. Aldiz, Linda Hutcheonen ikuspegian oinarrituz modernitatearen ikuspegi esentzialista gainditzea izan bide da postmodernismoaren ekarria, modu honetan barne diferentziez osoturiko errealitateari, niari edota nazioari azaleratzen utziz. "Ontologia diferentziala" deritzan honen bi ardatz nagusiak errealitatearen zehatz ezintasuna eta ezagutza mota oro interpretazioa delako baieztapena dira, giza adimenaren eta arrazoimenaren mugak onartuz. Hutcheonen iritziz, literatura postmodernistan parodia da testuartekotasun modu nagusia.

Esan daiteke Postmodernismo filosofikoak epistemologia berritu digula, Errealitatearen zerizana esentziek zedarritu beharrean barne diferentziek proiektatzen duela baieztatuz. Hainbat elementuren berdefinizioa erakarri digu horrek: munduko izakien zerizana, giza ezagutzaren ahalbideak, printzipio etikoen jatorria eta jarduera politikoaren helburuak, hain zuzen ere. Posmodernitatean jakintzak bere esanahia absolutua galtzeak, ondorioz, literatur testuen karga erreflexiboa hustea ekarri du, arinago, bigunago eta alde askotatik irensten errazago bihurtu ditu.

Mintzagai dugun Etiopia ez daiteke utopia modernoekin batean sailkatu, haien kuestionamenduak eta gainbeherak eragindako krisian kokatzen baita, hain zuzen ere. Alabaina krisi horren ondorioz erakusten duen jarrera ez da jarrera ludiko eta lasai hutsa, ordea; aitzitik, galderak luzatzen dizkio bere buruari, errealitatea kritikatzen du etorkizun hobe baten aldeko ahalegin utopikoan, eta gizataldea du erreferentzia. Ez dio berehalakotasun tenporalari ematen lehentasuna, ez espektakuluari berari atxikia geratzen; aitzitik, jarrera aktiboa hartzen du, errealitate etsigarria eraldatzea helburu duena, kosta ahala kosta.

Hiria, posmodernitatearen topografia maiteena, errealitate transformagarriaren sinbolotzat hartu du liburuak, eta poetaren egitekoa errealitate hori eraldatzea dela aldarrikatu izana da jarrera kritiko horren adierazle.

Ez dago ukatzerik gizaki modernoaren nia eta indibiduotasunaren ahultze prozesua, metafisikaren azkena eta nihilismoaren garaipena batzuk besteekin konektaturiko fenomenoak direla eta liburuan badu islapenik. Alabaina, ez dago Etiopian "pentsamendu ahula"ren zantzurik, ez arintasun edo biguntasunik, amore emate edo etsipenik, Etxahuni hirira etortzeko eginiko deian ongi garbi geratzen denez: euskal literaturak, euskal gizarteak badu utopia bat gauzatu beharra, bere garaiko bizitzari heldu eta bereganatzea dagokio, eta bizitza hori bere hitz propio eta bere nortasun beti ukatu, beti baztertu, beti menderaezinaz esatea ${ }^{89}$.

Eta zu ere abiatu zara, Ba zatoz Etxahun ortutsik, Mantekila eta mermelada eskuetan duzula;

Eta gariz jantzia ikusiko zaitugu ,

Gariz jantzia eta uda zabaltzen:

Uda, arrabitarik gabeko itsuentzat, eta Jondone sagarrak;

Uda, komunetan hiru mendez lo egin dugunontzat, gereziak

89.- Atxaga, Bernardo "El imposible vencido" Irene Andrés-Suarez y Antoni Rivas (ed) Bernardo Atxaga, UNEArco, Madrid, 2011, 13-26. 
Eta argia goizero.

Apiril edo Maiatzero bentzutuentzat, gorostia, ihiak;

Ekia eta dinamita .

Ez dadila bitrioluz galdu egunaren begia.

Sufrimenduak zorrozturiko labainak ere ekar, Etxahun

guretzat

Eta guretzat izan daitezela aizkorak ere

Ezinaren arrebontzat;

Ezaren alaba garenoi etor hakigu, Etxahun

Teilatu ustel horietan arkituko gaituk

Disparatzen apika;

Geure oinazea papurtu,

Eta usoei eskaintzen.

Eta sar hadi orainaren labirintoetatik barrena,

Utzi iraganaren abenidak;

Ez haugu behar gorpuak zitroi urez ihurtzitzeko

Baizik eta desertuko ihizik eragitearren

Ziutaterantz.

\section{BIBLIOGRAFIA}

\section{Bernardo Atxagaren obra poetikoa euskaraz}

Etiopia, Bilbo, Pott, 1978. Fotografías de J.M. Susperregui. Donostia, Erein, 1983.

Poemas \& Hibridos, Madrid, Visor, 1990.

Nueva Etiopia, Madrid, El Europeo, 1996.

XX. mendeko poesia kaierak. Bernardo Atxaga. ed. Koldo Izagirre Zarautz, Susa, 2000.

Paradisua eta katuak, Pamiela, Iruñea, 2012.

\section{Poemas E Híbridos liburuaren itzulpenak}

Catalán: Edicions Bromera, 1994.

Finés: Tammi Publishers, 2001.

Francés : Editions de la Presqu'île, 1995.

Italiano: Ugo Guanda, 2000.

\section{Liburu kolektiboetan bildutako poemak}

"Poemas" in Iñaki Aldekoa, Antología de la Poesía Vasca, Madrid, Visor, 1991.

"Tierras imaginadas" eta "Exposición de la carta del canonigo Lizardi", en Bernardo Atxaga et al., La condición humana. Diez relatos y un poema, Madrid, FNAC. Reedición: Plaza \& Janés, 1996.

"Poemas" in R. Rossi \& V. Gómez y Oliver (Eds.), Antologia della poesia spagnola, Nuove Amadeus Edizioni, 1996.

"Interiores y exteriores de la literatura (vasca)", Moderna-Sprak (Suecia), 1997, 91:1, pp. 8694. 
"Poesia", in AAVV, Cullita d'otri: antoloxia de poesía contemporania oczidental, Publicaciones del Consejo de Habla Aragonesa, 1998.

"Poems", AA.VV., en Transcript 5 (http://www.transcript-review.org), 2003.

"Six poems, two songs", in María José Olaziregi (Ed.), Six Basque Poets, Todmorden, Arc Publications, 2007, pp. 31-53.

"Basque", in AAVV., Standing Tall in Babel. Languages in Europe, Amsterdam, Ons Erfdeel, 2007.

"Life", in Wayne Miller \& Kevin Prufer (Eds.), New European Poetry, Graywolf, 2008. Traducción de Margaret Jull Costa.

"Poems" in Hellen \& David Constantine (Ed.), Modern Poetry in Translation. Getting it Across, Oxford (Reino Unido), 2008. Traducción de Margaret Jull Costa.

"Poems", in AAVV., The Other Voices International Project (UNESCO), vol. 35. Traducción de Margaret Jull Costa.

"Death and the Zebras", in Tom Lombardo (Ed.), After Shocks. The Poetry of Recovery for Life Shattering Events, Atlanta, Sainte Lucia Books, 2008.

"Poems" en la revista canadiense BRICK (zb. 84, 2010.

"Poems" en la revista Hayden's Ferry Review de la Arizona State University, 2009.

ATXAGA INTERNETen: www.atxaga.org

\section{Bernardo Atxagaren poesiari buruzko bibliografia}

Aldekoa, Iñaki, (1991), "La poesia de B.Atxaga, Entre la Vanguardia y Obaba", revista ZURGAI, diciembre 91, Bilbao, 42-43.

Aldekoa, Iñaki, (1992) Antzara eta ispilua [La oca y el espejo], Donostia, Erein.

Aldekoa, Iñaki (1993a) "La neovanguardia: Bernardo Atxaga" in Antologia De la poesia vasca, Madrid, Visor, 26-29.

Aldekoa, Iñaki (1993c) Zirkuluaren hutsmina, Irun, Alberdania, 121-127.

Aldekoa, Iñaki, (1997b), "Modernitatea euskal literaturan (1950-1996)" en AA.VV., LUR Entziklopegia Tematikoa. Eukal Hizkuntza eta Literatura, 361-402.

Aldekoa, Iñaki (1998), "Paganismo y última poesía vasca", RLLGCV-V, 315-323.

Aldekoa, Iñaki (1999a), "De l'avantgarda a Obaba", L'Aljamia 14, 40-43.

Aldekoa, Iñaki, (1999b), "Bernardo Atxagaren unibertso literarioa (1976-1988)". Literatura eta Kritika" [El universo literario de BA. Crítica y Literatura] en AA.VV. Atxaga Baionan [Atxaga en Baiona], Donostia, Hiriak-Egan, 15-32.

Aldekoa, Iñaki, (2000) "La poesía del XX", en Urquizu, P., Historia de la literatura vasca, Madrid, UNED, 496-498.

Aldekoa, Iñaki (2004), Historia de la Literatura Vasca, Donostia, Erein.

Aldekoa, Iñaki (2009), "Bernardo Atxagaren Etiopia", in AA.VV. "Juan María Lekuonari omenaldia” IKER 23, Euskaltzaindia, 2-24.

Andres-Suarez, Irene \& Antonio Rivas, Bernardo Atxaga, Gran Séminaire de Neuchâtel, Coloquio Internacional Bernardo Atxaga", Universidad de Neuchâtel (Suiza) y ARCO/ LIBROS,Madrid, 2011.

Apalategi, Ur (2006), "Ciudades y cambios de personalidad", Cuadernos de Alzate 35, 2006, 101-120.

Apalategi, Ur (1997), Évolution de la problemátique littéraire de Bernardo Atxaga, du champ 
littéraire basque au champ universel. Socionalyse du pathos atxaguien, Université de Pau et des Pays de l'Adour. Tesis doctoral.

Apalategi, Ur (1998), "Atxaga, Sarrionaindia et tant d'autres. L'invention d'une litterature basque" [Atxaga, Sarrionaindia y muchos otros. La invención de una literatura vasca] en Laborde, D. (ed.), La question basque, Paris, L’Harmattan.

Apalategi, Ur (2000), La naissance de l'écrivain basque. L'évolution de la problématique littéraire de Bernardo Atxaga, Paris, L’Harmattan.

Arana, lide y OtAegi, Lourdes (1980), "Atxagaren Etipiaz zenbait apunte", revista Xaguxarra, Hordago, 123-132.

Ascunce, José Angel (2000), Bernardo Atxaga, los demonios de un escritor, Donostia, Ed. Saturrarán.

Atxaga, Bernardo, "Poética", in "El estado de las poesías", Cuadernos del Norte, 2, Oviedo,1986, 148-150.

Azkorbebeitia, Aitzpea (1996), "Bernardo Atxaga eta Joséba Sarrionaindiaren metaforetan barrena bidaiatuz", Uztaro 17, 109-149.

Azkorbebeitia, Aitzpea (1997), "Bernardo Atxagaren testuetara hurbilpen bat Harrera-Teoriaren eskutik", ASJU XXIX-2, 1995, 455-498.

Azkorbebeitia, Aitzpea (1999), "Hamaika hitz Bernardo Atxagaren unibertso metaforikoaz, eta bat gehiago" en AA.VV. Atxaga Baionan [Atxaga en Baiona], Donostia, Hiriak-Egan, 119-151.

Ballaz, Jesús (1997), "La función social de la literatura", Clij 96, julio-agosto de 1997, 2429.

Barella, Julia (1981), «Poesía en la década de los 70: en torno a los novísimos», Ínsula, 410

Barella, Julia (1983) «La reacción veneciana: poesía española en la década de los setenta», Estudios Humanísticos, 5.

Barella, Julia (1988) «Poesía de los 70», Ínsula, 498.

Barnatán, Marcos Ricardo (1984), «Cuando los novísimos comenzaban a serlo (Tres fragmentados años de la década prodigiosa)», Barcarola, 16-17.

Barnatán, Marcos Ricardo (1989), «La polémica de Venecia», Ínsula, 508.

Carnero, Guillermo (1989), Las armas abisinias. Ensayos sobre literatura y arte del s. XX, Barcelona, Anthropos.

Carnero, Guillermo, (1998) Entrevista realizada por Ángel Manuel Gómez Espada en http://www.elcoloquiodelosperros.net/numero3/olfateando.htm

Casado, Miguel (1990) "Bernardo Atxaga: Poemas \& Hibridos", El Urogallo 52-53, 80-81.

Crespo, Ángel (1973-77), Divina Comedia. Seix Barral, Barcelona, Infierno (1973), Purgatorio (1976) Paraiso (1977).

Eliot, Thomas, Stearns (1978) Poesias reunidas 1909/1962, Madrid, Alianza tres. Introducción de José María Valverde.

Etxeberria, Guillermo (ed.) (1999), Atxaga Baionan [Atxaga en Baiona], Donostia, EganHiria.

Fernández, J. Benito: El contorno del abismo. Vida y leyenda de Leopoldo María Panero, Barcelona: Tusquets, 2006.

Gabilondo, Joséba (1993), "Kanonaren sorrera egungo euskal literaturan. Etiopiaz", Egan XLV, 33-65.

Garcia Carcedo, Pilar (1993), "De Blas de Otero a Bernardo Atxaga", Cuadernos 
hispanoamericanos, $\mathrm{N}^{\circ}$ 520, 133-136.

Garcia de la concha, Victor, (1987) La poesía española de 1935 a 1975, Madrid, Cátedra.

Genette, Gérard, (1982) Palimpsestes. LaLittérature au second degré, Seuils, Paris. Gaztelaniazko itzulpena : Palimpsestos. La Literatura en segundo grado, Taurus, Madrid, 1989,

Genette, Gérard (1989) Seuils, Seuils, Paris. Gaztelaniazko itzulpena: Umbrales, Siglo XXI, Madrid, 2001.

Hutcheon, Linda (1989)The Politics of Postmodernism. London \& New York: Routledge.

Jameson, Fredric (1985) "Posmodernismo y la sociedad de consumo". La Posmodernidad.

Hal Foster (ed.). Kairós: Bacelona. (Jatorrizkoa:"Postmodernism and the consumer society". The Anti-Aesthetic. Essays on Postmodern Culture. Hal Foster (ed.). Bay Press: Port Townsend, Washington,1983).

Juaristi, Jon (1987), Literatura vasca, Taurus, Madrid, (132-133).

Kortazar, Jon (1986) "La moderna poesía vasca. Una visión", en El estado de las poesías, Cuadernos del Norte, 132-138, Oviedo.

Kortazar, Jon, (1987) "Poesía compromesa a Euskadi. Un acostament a la historia y a la literatura", Daina 2, 35-50.

Kortazar, Jon, (1988) "'Etiopia' ondorengo poesia", Literatur Gazeta 10, 1-5.

Kortazar, Jon (1994) "El desierto, la selva y la ciudad", Bitarte 2, 61-73.

Kortazar, Jon, (1997) "Etiopia Walter Benjaminen begiradapean" in Luma eta Lurra, Bilbao, Labayru, 37-97.

Kortazar, Jon (1998c) “A poesía vasca, 1980-1995”, Grial 140, 753-761.

Kortazar, Jon, (1999c) La pluma y la tierra. Poesía vasca contemporánea (1978-1995), Prames, Zaragoza.

Kortazar, Jon, (2001e) Pott bandaren poesia. Oroimenaren eszenatokiak, Bilbo, Labayru.

Kortazar, Jon (2005), Literatura vasca desde la transición: Bernardo Atxaga, Madrid, Ediciones del Orto, 94 p. Traducción al inglés: Bernardo Atxaga. Basque Literature fron the End of the Franco Era to the Present, Reno, Center for Basque Studies-University of Nevada, Reno, 2005, 97 p. Traducido por Kristin Addis.

Kortazar, Jon (2005), "De la lengua, de la vida. Sobre un poema de Bernardo Atxaga", Revista de Occidente 285, Febrero 2005, 122-132.

Kortazar, Jon (2007), Bernardo Atxaga: Basque Literature From The End Of The Franco Era To The Present, University of Reno, 2007.

Lanz, Juan José (1993) "La luz inextinguible" in Ensayos sobre literatura vasca actual, Madrid, Siglo XXI, 80-93.

Lanz, Juan José (1994), "La poesía de Bernardo Atxaga. Poemas \& Híbridos", Insula 526, (2930)

Lanz, Juan José (1994) La llama en el laberinto (Poesía y poética en la generación del 68), Mérida, Editora Regional de Extremadura, 1994.

Lanz, Juan José, (1998), "La joven poesía española. Notas para una periodización», Hispanic Review, 66 (1998).

Lanz, Juan José (1999), «La poesía», en F. Rico (dir.), Historia y crítica de la literatura española. Época contemporánea 1939-1975, 8.1, Barcelona, Crítica, 1999.

Lanz, Juan José (2000) Introducción al estudio de la generación poética española de 1968, Bilbao, Universidad del País Vasco, 2000.

Lanz, Juan José (2000) "Aresti, la piedra. Atxaga, la arena", en AA.VV. (2000) El Tiempo y sus 
símbolos. Cultura de la Temporalidad, Etor-Ostoa, Lasarte-Oria, 66-73.

Lasagabaster, Jesús María (1985) «Literatura y vida literaria», en AA.VV. (1985) Euskal Herria.

Errealitate eta egitasmoa. Realidad y proyecto II, Donostia, Lankide Aurrezkia, 427433.

Lasagabaster, Jesús María, (1987a) "La literatura vasca", en AA.VV. (1987) Letras españolas. 1970-1986, Castalia, Madrid, 283-303.

Lasagabaster, Jesús María (2005), Las Literaturas de los Vascos, Bilbao, Deusto.

Lopez Gaseni, Manu (2002), Historia de la Literatura Vasca, Madrid, Acento, 2002.

López-Casanova, Arcadio, El texto poético. Teoría y metodología, Salamanca, Colegio de España, 1994, 60-

López-Casanova, Arcadio (2007), Macrotexto poético y estructuras de sentido. Análisis de modelos líricos modernos, Valencia, Tirant Lo Blanch.

Mercero, Gorka (2005), "Bernardo Atxagaren Lekuak: obaba, edo 'Arrazoímodernoa eta oroimen postmodernoaren arteko borroka", Lapurdum X, 117-126.

Morales, Andoni (1992), "PoemasEHíbridos-en zehar eginiko gogoeta eroak", Enseiucarrean, 8, 105-143.

Olaziregi, María José (1997), Literatura eta irakurlea. Testu-estrategietatik soziologiara Bernardo Atxagaren unibertso literarioan [Literatura y lectura. De la sociología a las estrategias textuales en el universo literario de Bernardo Atxaga], Universidad del País Vasco. Facultad de Filología, Geografía e Historia. Vitoria. 16-1-97. Tesis doctoral.

Olaziregi, María José (1998) "Bernardo Atxaga: El escritor deseado", Ínsula 623, 7-11.

Olaziregi, María José (1998), Bernardo Atxagaren irakurlea [El lector de Bernardo Atxaga], Donostia, Erein.

Olaziregi, María José (2002), Leyendo a Bernardo Atxaga, Bilbao, Universidad del País Vasco.

Olaziregi, María José (2000), "La trayectoria literaria de Bernardo Atxaga", Sancho el Sabio $13,41-56$.

Olaziregi, María José (2000), "Mémories d'une lectrice de Bernardo Atxaga", Revue des livres pour les enfants 192, avril 2000, págs. 91-96.

Olaziregi, María José (2005), Waking the Hedgehog. The Literary Universe of Bernardo Atxaga, Reno (USA), Center for Basque Studies, University of Nevada, Reno.

Olaziregi, María José (2009), "Basque Poetry", en Princeton Encyclopedia of Poetry and Poetics, Fourth Edition, Princeton University Press.

Olaziregi, María José (2011) "Los lugares de la memoria en la narrativa de Bernardo Atxaga" in Irene Andres-Suares y Antonio Rivas, Bernardo Atxaga, Arco, Madrid, 43-62

Otaegi, Lourdes, \& Arana, Lide, (1980), "Atxagaren 'Etiopia'z zenbait apunte", Xaguzarra 1980-1, 123-130.

Otaegi, Lourdes, (2010)“Basque Poetry of the XXth Century", en María José Olaziregi (Ed.), History of Basque Literature. En preparación.

Otaegi, Lourdes (1999), Bernardo Atxaga. Egilearen hitza [Bernardo Atxaga. La palabra del autor], Bilbo, Labayru, 1999.

Otaegi, Lourdes, (2011) "Nueva introducción a la obra poética de Bernardo Atxaga (11978) in Irene Andres-Suarez y Antonio Rivas, Bernardo Atxaga, Arco, Madrid, 147-181.

Otaegi, Lourdes, Poesia del siglo XX in www.Basquesliterature.com

Schwob, Marcel (2002), "Cecco Angiolieri. Poeta gorrototsu" in Bizi alegiazkoak, Ibaizabal, Bilbo 2002. Prólogo de Iñaki Aldekoa y traducción de Joan Gartzia.(81-87). 
Uribe, Kirmen (1998), "Asalto a los cielos estética y escritura en la poesía de Atxaga y Sarrionandia”, Insula 623, 23-25.

Valverde, J. M. \& RiQueR, M. DE, (1986), "El caso de la literatura vasca", Historia de la Literatura Universal. Tomo 10. De las Vanguardias a nuestros días II, Barcelona, Planeta, 225 y ss.

White, Linda (2000), "A Literature in Chains: Literatura kateatuta." Published on the Institute of Basque Studies (London) web site at: http://ibs.lgu.ac.uk/sympo/page4.html

\section{Bernardo Atxagari egin elkarrizketak}

AAVV (entrevista) "Atxagarekin hizketan" in Susa, 1982, apirila, 3- 12.

Aussenac, Dominque, 2007, Le main du signe, 2007ko apirilean)Ikus www.atxaga. org esteka (2013-04-15ean irakurria).

Etxeberria, Hasier, 2002, "Bernardo Atxaga", en Cinco escritores vascos, Alberdania, Irun, pp.315-370.

Lanz, Juan José, 1990a, "Con BA", ZURGAI, 12-1990, 99-101.

Lanz, Juan José, 1990b, "BA o la literatura como ilustración”, El Urogallo 55-56, 90-12/91, 14-21.

Lertxundi, Anjel., 1989, "BA, entrevista", El Urogallo 41, 9-7-1989, 40-43.

Linea d'Ombra, 1993, "Euskaraz idazteari buruz", Luxia 1, 9-14 (Publicado en 1991 en la revista Linea d'Ombra de Milán en su no 66. Es una variante de lo que la bilbaína Amalia Iglesias publicó en el periódico Diario 16.)

Mollarri, J., 1982, "Susa berezia: Bernardo Atxaga eta Literatura", Argia 933, 16-5-1982, $32-$ 33

Olaziregi, María José, "Encontros en Reno con Bernado Atxaga: un escritor no deserto", Boletín Galego de Literatura, n. 36-37, 2007, pp. 247-254.

Sobolewska, Ana, 1993, "Inter-testualitateari buruz", Luxia 1, 15-22

Susa, 1982, "Atxagarekin hizketan?: Pott banda, neure burua eta gainerakoak", Susa 5, 14-21 Vilavedra, Dolores, 1995, "Entrevista con BA", Grial XXXIII, julio-agosto-setiembre de 1995, 427-434.

Yoldi, P., (1992), "La llamada del bosque (entrevista a BA)", Integral. 156, 32-37. 
